What's The Point?: The Meaning of Place, Memory, and Community in Point Saint Charles, Quebec

Jessica J. Mills

\author{
A Thesis \\ in \\ The Department \\ of \\ History
}

Presented in Partial Fulfillment of the Requirements for the Degree of Master of Arts (History) at Concordia University

Montreal, Quebec, Canada

April 2011

(C) Jessica J. Mills, 2011 


\section{CONCORDIA UNIVERSITY}

\section{School of Graduate Studies}

This is to certify that the thesis prepared

By: $\quad$ Jessica J. Mills

Entitled: $\quad$ What's The Point?: The Meaning of Place, Memory, and Community in Point Saint Charles, Quebec

and submitted in partial fulfillment of the requirements for the degree of

\section{Master of Arts (History)}

complies with the regulations of the University and meets the accepted standards with respect to originality and quality.

Signed by the final examining committee:

Dr. Frederick A. Bode Chair

Dr. Barbara Lorenzkowski Examiner

Dr. Ronald Rudin Examiner

Dr. Steven High Supervisor

Approved by Dr. Wilson Chacko Jacob Chair of Department or Graduate Program Director

April $7^{\text {th }}, 2011$ Dean Brian Lewis Dean of Faculty 


\begin{abstract}
What's The Point?: The Meaning of Place, Memory, and Community in Point Saint Charles, Quebec Jessica J. Mills
\end{abstract}

In Point Saint Charles (The Point), concepts of place, memory, class, and community cannot be understood in isolation. As the area undergoes socio-economic changes, the struggle over what The Point is, how it got there, and who belongs within it, is contested. The public history of industrialization and industrial decline contributes to a homogenous memory of class that is threatened by gentrification. This reinforces a defensive stance compounded by negative experiences of "urban renewal". However, the gentrification underway does not fit the traditional model, complicating these themes considerably. This thesis traces the shifting temporal and spatial understandings of place, exploring the fluid nature of The Point's symbolic and physical boundaries - how they came to be and how they inform public history, place attachment, and the use of community. These meanings are contributing to the creation of a "community of memory" negotiated predominantly through social media sites. "Pointers" are smoothing out conflicting memories, and silencing dissent within the group, while asserting difference from "others". The construction of this community represents a struggle over place identity made manifest by gentrification and is highly nostalgic. This use of community no 1 onger requires residency for inclusion, instead "Pointers" depend on symbols, rituals, and a flexible notion of time to carve out a space of acceptance. 


\section{Acknowledgements}

Although a cliché, it is true nonetheless: This thesis would not have been possible without the support and encouragement of multiple people. First I'd like to thank my supervisor, Dr. Steven High who provided guidance and encouragement through the murky waters that can be graduate school. I'd like to thank my committee, Dr. Ronald Rudin and Dr. Barbara Lorenzkowski, and the many other professors at Concordia University who deepened my historical understanding and nourished my love of learning. I must also acknowledge the Social Science and Humanities Research Council (SSHRC) whose generous funding allowed me to delve into my research.

I am also extremely grateful to the people of Point Saint Charles who shared their stories with me. While I might not be a Pointer, I do hope that I'll become one, one day.

This thesis has benefited from in depth discussions, writing sessions, and bouts of distraction with my history peers, especially Samah Afran, Kristin Biefer, Derek Caners, Will Hamilton, Alex Leonard, Chris Miller, Lindsay Pattison, Marie Pelletier, Scott Selders, Jessica Silva, Andrew Welsch, and Stacey Zembrzycki. They all probably know as much about my thesis as I do. I would be remiss to not mention the patience of my friends and colleagues. Gillian Vogel and Susie Bouchard, in particular listened to me as I tried to wrap my head around my purpose and direction and lamented my decision to write a thesis. That they are still my friends after my frequent absences is a testament to their characters. Kara Zemel also provided research support and distraction. My colleagues at the Office of Instructional Development at Dawson College were also incredibility supportive of my scholarly endeavours even when these took me out of the office. This encouragement has been invaluable. 
Importantly, I have to thank my family; my mom, Joanne, sister Catherine, and brother Christopher, have helped me become who I am and are a constant source of inspiration. I would have never learned to take risk without my mother, argue without my brother, or create without my sister.

Finally, to my husband and best friend Dave, whose patience knows no bounds. His constant support through my periods of underemployment, marathon sessions in front of my computer, and stress-induced breakdowns has shown me, once again, how lucky I am to have him my life. I love you. 


\section{Dedication}

This thesis is dedicated to the memory of my father, David Mills, whom I miss dearly. 


\section{Table of Contents}

List of Illustrations $\quad$ vii

List of Maps $\quad$ viii

Introduction 1

Chapter 1: Placing The Point 15

Chapter 2: Bringing Class Back to The Point 41

Chapter 3: Putting the Unity back in Community 65

$\begin{array}{lr}\text { Conclusion } & 89\end{array}$

$\begin{array}{ll}\text { Bibliography } & 96\end{array}$ 


\section{List of Illustrations}

Figure 5.1: Whose Land? 


\section{List of Maps}

Map 1.1: Point Saint Charles within the island of Montreal

Map 2.1: Point Saint Charles, 1881

Map 2.2: Point Saint Charles out of context 


\section{Introduction}

Cries of "one dollar a day!" and "no m ore company stores!" rang out in early September 2009, when "protesters" from the Point Saint Charle s Community Theatre took to the stage as part of the annual Joe Beef Market in the Montreal district of Point Saint Charles. Wearing my closest approxi mation of 1870 s working-class attire, I was among those confronting audience members. What brought me there? The answer to this question requires some reflection.

My introduction to "The Point", as Point Saint Charles is often known, cam e in 2006, when residents and activists made headlines after successfully preventing a Casino from being built in th e neighbourhood. Despite having lived in Montreal for $\mathrm{m} y$ entire life, albeit in Pointe Claire in the Anglophone west end of the island, I had no recollection of ever having heard of The Point before. The fight against the Casino followed a longline of grass-roots initiatives, including the establishment of a Legal Aid Clinic and a Community Health Clinic which are both still active today . ${ }^{1}$ The positive gains for the community, despite th e challenges faced by the neigh bourhood - and the implied cohesion of the citizens - drew me to the area.

Located South-West of downtown Montreal, Point Saint Charles is an informal designation named in honour of Charles Lem oyne. It was once divided in half by the St Ann's Ward and St Gab riel Village but now, within the larger municipal structure, it is housed by its official borough, the appropriately named Sud-Ouest. In 2007, having lived for several years in neighbouring Saint Henri, I grew tired of renti ng and started looking to buy property. The Sud-Ouest appealed to me, it was an area in transition which, with a

\footnotetext{
${ }^{1}$ For a detailed explanation of the history of activism in Point Saint Charles, see, Anna Kruzynski and Isabelle Drolet, eds., The Point Is-- Grassroots Organizing Works: Women from Point St. Charles Sharing Stories of Solidarity (Montréal: Éditions du remue-ménage, 2006).
} 
limited budget, offered the possibility of finding a suitable space. After a long period of looking I found the place I wanted to buy: a rowhouse built in 1885 and in need of substantial work. In quick succession, I became a new resident of an a rea where identity was changing as fast as its socio-econom ic status. Since moving, I began to see the complexities within the story and the ways in which place, class, community and memory were being negotiated in the changing landscape . My for ay into real estate had thus, rather unintentionally, provided the subject matter for this work.

If home ownership was the catalyst for this thesis, then it is also what brought me onto the stage that Septem ber; however, the inspiration behind the market is rooted long ago, predating even my house. The event's namesake, Joe Beef, né Charles McKiernan, was a storied late $\mathrm{n}$ ineteenth-century tavern owner who, historia $\mathrm{n}$ Peter Delo ttinville argues, played a fundam ental role in deve loping a working-class culture in Montreal which "offered an alternative to the indiv idualist, competitive philosophy of the nineteenth-century middle class." ${ }^{2}$ Delottinville's widely read 1981 article revived Joe Beef's memory but it was playwright David Fennario's 1984 work, Joe Beef: A History of Point Saint Charles, that linked the character with the neighbourhood.

For the past three years, Joe Beef has reappeared in The Point as part of the Point Saint Charles (PSC) Community Theatre and Société d'histoire de Pointe-Saint-Charles's market, where he hands out free soup in hom age to his role during one of the Lachine Canal strikes. ${ }^{3}$ Facing the audience, it occu rred to me that Joe Beef had becom e an

\footnotetext{
${ }^{2}$ Peter DeLottinville, "Joe Beef of Montreal: Working-Class Culture and the Tavern, 1869-1889," Labour/Le Travail 8 (1981): 11.

${ }^{3}$ In 1874 , labourers, the majority of whom were Irish and French Canadian, began enlarging the Lachine Canal. Working under difficult conditions in the dead of winter, and frustrated by their treatment, the labourers went on strike in December 1877. This event provided the background that brought me to the stage in September 2009. As one thousand workers, demanded a wage of one dollar a day, shorter working hours, and an end to payment in credit redeemable at company stores, Joe Beef provided support. On the
} 
allegory for Point Saint Charles. In The Point's appropriation of Joe Beef's memory, the shifting nature of place is revealed: there is no particular link to tie him to the area. His canteen was housed in two buildings, first on St Claude S treet and then on Common Street, both located in the Old Port area of Montreal, yet the annual Joe Beef Market is held in the park that bears his name at the corner of Centre and Richmond Streets, with the proximity of the Lachine Canal as the only thing that ties them together. The memory of Joe Beef as hero to, and defender of, the working class is symbolic of the modern day tensions of urban change: the strikers of old are replaced by the Point's long-time residents, and Montreal's former gentry supplanted by modern gentrifiers. In this role, little of the controve rsy that dogged McKiernan, of whic $\mathrm{h}$ there was plenty, ever makes its way into popular memory. ${ }^{4}$ Therefore, the re-creation of his public mem ory provides a window through which vestiges of The Point's past, glim pses of its future, and suggestions of the meanings infused into its present, can be seen.

Historians James Opp and John C. Walsh define public m emory as "memories that are made, experienced, and circulated in public spaces and that are intend ed to be communicated and shared." 5 Public $\mathrm{m}$ emories of The Point are rooted in chang ing economic cycles and modes of production. The Point's built beginnings sprang from several farms controlled by religious orders. By the turn of the twentieth century, spurred by the construction of the Lachine Canal, The Point had becom e a mix of industry and

morning of December $20^{\text {th }}$, for instance, McKiernan provided 300 small loaves of bread, 36 gallons of soup and 36 gallons of tea. He housed as many strikers as he could in the rooms above his tavern and is credited with easing a tense situation between the strikers and the Prince of Wales Rifles when he sent bread to the men on duty who then gave it to the strikers. While canal managers saw Joe Beef as a threat, his oratory skills attracted attention to the plight of the workers. These actions led "hundreds of hundreds of labours to his canteen to show their respect, indicating his influence. DeLottinville, "Joe Beef of Montreal," 21; The Montreal Star, December 20, 1877; The Montreal Star, December 21, 1877.

${ }^{4}$ For some of the controversies see: DeLottinville, "Joe Beef of Montreal."

${ }^{5}$ Introduction in James Opp and John C. Walsh eds., Placing Memory and Remembering Place in Canada (UBC Press, 2010), 9. 
residency. A period of severe industrial decline peaked in the 1960s, leaving residents of The Point struggling, but defiant. These memories are often communicated in opposition to gentrification, which started modestly in the late 1980s, but gained considerable momentum in the last five years. S haring these stories contributes to what Sherry Lee Linkon and John Russo would call The Point's "constitutive narrative": they provide a "unifying image" of the importance of the area, first to the city's religious foundation and later to Canada's industrial identity. ${ }^{6}$

The "unifying im age" is, in turn, us ed to evoke notions of community . Anthropologist, Anthony P. Cohen has urged us to look at the uses of community rather than strive for a definition ${ }^{7}$, and historian Elizabeth Faue ha s reminded us that the use of community often "obscures the complex meanings, experiences, and identities associated with place, space, locality and $\mathrm{p}$ olitical unit”8. Exclusion from , or inclusion in, communities depends on a caref ul negotiation of meaning behind similarity and difference, privileging of sp ecific group characteristics, a nd various understandings of place. A "community of m emory" in Poin t Saint Charles depends heavily on the constitutive narrative of the area for , as Linkon and Russo posit, "communities of memory continually retell their stories, and this process creates a sense of shared history and identity, out of which they de velop vision and hope for the future." ${ }^{9}$ Often regarded as factual and official, these stories rely on experience to reinforce their authenticity.

\footnotetext{
${ }^{6}$ Sherry Lee Linkon, Steeltown U.S.A: Work and Memory in Youngstown, Culture America (Lawrence, Kan: University Press of Kansas, 2002), 2.

${ }^{7}$ Anthony P Cohen, The Symbolic Construction of Community, Key ideas (Chichester: E. Horwood, 1985), 12.

${ }^{8}$ Elizabeth Faue, "Community, Class, and Comparison in Labour History and Local History," Labour History (2000): 159.

${ }^{9}$ Linkon, Steeltown U.S.A, 3.
} 
Historian Joan Scott questions this priv ileging of experience which, she ar gues, can prevent exploring difference and constructs a conclusive expl anation "beyond which few questions can or need be asked". ${ }^{10}$ Philosopher and historia $n$ Michel de Certeau, in the context of what constitu tes experience, argues that s tories provide a containe $r$ for everyday practices, produce schemas for actio $\mathrm{n}$, and have a historical foundation. This narrated history creates a fictional space which is inseparable from the time in which the memory was attained. Historian Alessandro Portelli posits that "oral sources tell us not just what people did, but what they wanted to $\mathrm{d} o$, what they believed they were doing, and what they now think they did" giving us insight into the meaning of the events. ${ }^{11}$ De Certeau links these ideas by ar guing that ultimately, every story is a spatial practice and space a practiced place, and that "th e memorable is that which can be dreamed about a place". ${ }^{12}$

Human Geographer, Tim Cresswell posits th at place, notoriously hard to define, involves creation, and that physical spaces can be different places to dif ferent people. Ultimately, scholars agree tha $t$ the key to place -making is meaning: places are "spaces that people have made meaningful." ${ }^{, 13}$ Geographer Yi-Fu Tuan elaborates that place is "a center of meaning constructed by experience". ${ }^{14}$ There is no doubt that the landscape of The Point has been marked by its experience.

Notions of place, $\mathrm{m}$ emory, class, and community can not be und erstood in isolation; these related ideas are intricately linked, each one informs the others. In The

\footnotetext{
${ }^{10}$ Joan W. Scott, “The Evidence of Experience," Critical Inquiry 17, no. 4 (July 1, 1991): 790.

${ }^{11}$ Portelli, Alessandro, "What Makes Oral History Different," in The Oral History Reader, ed. Robert Perks and Alistair Thomson, 2nd ed. (London: Routledge, 2006), 36.

${ }^{12}$ Michel de Certeau, The Practice of Everyday Life (Berkeley: University of California Press, 1988), 109.

${ }^{13}$ Tim Cresswell, Place: A Short Introduction, Short introductions to geography (Malden, MA: Blackwell Pub, 2004), 7.

${ }^{14}$ Yi-Fu Tuan, "Place: An Experiential Perspective," Geographical Review 65, no. 2 (April 1, 1975): 152.
} 
Point, this process is $\mathrm{m}$ ade manifest by the ongoing gentrification. The accelerating nature of The Point's gentrification is changing the area its elf. While the transformation of the Lachine Canal into a leisure space and the conversion of Redpath Sugar into luxury lofts in the early 1990s brought wealthy residents into the area, this enclave failed to change the neighbourhood extensiv ely, traversing the canal in to the city rather than venturing deeper into The Point. The crux of gentrification has com e from inside The Point rather than its edges. It is here th at affordable condos and housing stock in various stages of distres s have attracted what human geographers Mathieu Van Criekingen and Jean Michel Decroly w ould call "marginal gentrifiers": new residents who do not $\mathrm{m}$ eet the traditional definition $b$ ecause of their socio-econo mic or socio-dem ographic profiles. ${ }^{15}$ As the area under goes its current tr ansformation the struggle over what The Point is, how it got there, and who belongs within it, is contested.

The pages that $f$ ollow build on current literatu re. For instanc e, existing scholarship examines the 'making of' this working-class district during the period of the industrialization. Geographer Robert Lewis is particularly interested in the process of industrial development, whereas historians Terry Copp and Bettina Bradbury examine the social impact of this econom ic transformation. On the other hand, while Matthe w Barlow and I have addressed sim ilar themes, including the shifting nature of place, the impact of urban change, varying uses of history, and the ce ntrality of memory, Barlow focuses on the Irish experience and neighbouring Griffintown. It is here we diverge, since as B arlow argues, the process of deindustrialization and depopulation of Griffintown was significantly different: "[i]t was not the target of [urban rene wal]...

\footnotetext{
${ }^{15}$ Mathieu Van Criekingen and Jean-Michel Decroly, "Revisiting the Diversity of Gentrification: Neighbourhood Renewal Processes in Brussels and Montreal," Urban Studies 40, no. 12 (November 1, 2003): $2451-2468$.
} 
Griffintown experienced devastation almost by accident". ${ }^{16}$ As such its memory is used for similar, but different purposes.

This thesis is based on extensive prim ary research including newspapers, archival sources, oral and digital narratives, artistic works, and public histories. A close reading of relevant newspaper articles provided insight into the development of the Lachine Canal, the life of Joe Beef, and th e changing nature of The Point. Community arch ives preserved by Les Archives populaires de Pointe-Saint-Charles, including documents from the Point Saint Charles Comm unity Clinic, le R egroupement information logement, and le Carrefour d'éducation populai re de Pointe-Saint-Charles, also of fered a wealth of information. Les Archives populaires de Poin te-Saint-Charles closed in 2007 afte $\mathrm{r}$ its holdings had been transferred to the McGill University Archives where they are available for consultation

As a book c o-written by women activists about their experiences and successes, The Point Is: Grassr oots Organizing Works: Women from Point St. Charles Sharing Stories of Solidarity, coordinated by Isabelle Drolet and Anna Kruzynski, is a celebration of the neighbourhood's history of activism, particularly in the late 1960 s and 1970 s. ${ }^{17}$ For the project, Drolet and Kruzynski conducted Francophone and Anglophone group interviews over 51 sessions, spanning several years. Here, I benefited not only from the published material, which I largely treat as a primary source, but also, from the interviews themselves. I consulted and used the content of these, but have elected to not quote the participants directly. Here, I refer to them as the women of the Courte Point Collective, a name that comes from the book. The only exception is when content comes directly from

\footnotetext{
${ }^{16}$ John Matthew Barlow, “"The House of the Irish": Irishness, History, and Memory in Griffintown, Montréal, 1868-2009" (Concordia University, 2009), 17.

${ }^{17}$ Kruzynski and Drolet, The Point Is-- Grassroots Organizing Works.
} 
the published material. ${ }^{18}$

This thesis also draws upon four life st ory oral history interviews with Mike Martello, Denis Sm yk, Rita Walters, and Lind a Wright, who all graciously agreed to spend some time with me and share their m emories. ${ }^{19}$ All four experienced The Point differently, and have varyi ng interests in its future. ${ }^{20}$ I was fortunate to have had the opportunity to hear th eir stories, especially as I faced complex challenges soliciting interviews. To begin with, there was a level of distrust about my role as researcher and my status as a n ew resident. Moreover, people freque ntly exclaimed that their experiences were not im portant enough. While this is a recurrent hurdle for oral historians, in The Point, it was reinforced by a series of past experiences that privileged a certain kind of knowledge. Due to its histor y with radical activism, supported by various universities, The Point was of ten the subject of studies. This led to an elem ent of research fatigue com pounded by an alleged failure to circulate the results am ong participants. $^{21}$

Public sources and artistic projects also in formed my research. I drew heavily on the various works by Davi d Fennario, particularly Joe Beef: A History of Point $S$ aint

\footnotetext{
${ }^{18}$ I have chosen this approach due to a concern I had about consent. When I consulted these sources, now housed in the McGill University Archives, and well into my research, I was confronted with a problem; I found the original consent forms which specified that the interviews were only to be used for the book. The archivist assured me that despite my concern, these interviews were open. After carefully weighing the implications of this, and factoring in several considerations, which included the knowledge that the fonds held at the McGill University Archives were donated by the Archives Populaire. Anna Kruzynsi and Isabelle Drolet, the facilitators of the interviews also ran the Archives Populaire. Ibid.

${ }^{19}$ Linda Wright is a pseudonym.

${ }^{20}$ Denis Smyk's grandfather settled in The Point and his parents owned a corner store during his youth. He eventually left, and he does not feel a strong attachment to the place. Mike Martello also grew up in the area before moving on. He still visits frequently, and The Point factors largely into his identity. Rita Walters spent most of her life in The Point. Raising her children and being active in various community organizations has created a strong bond with the neighbourhood. Linda Wright still lives in The Point but doesn't feel tied to the area and is considering leaving once her daughter finishes school.

${ }^{21}$ Groupe anglophone, "Tissons une courtePointe: L'histoire de l'action communautaire a travers les histories de vie de femmes de Pointe St-Charles.," interview by Isabelle Drolet and Anna Kruzynski, May 7, 2002, MG 4263, Acc. 2008-0024, McGill University Archives.
} 
Charles $^{22}$ and Balconville, ${ }^{23}$ Like oral history, these works tell us less about events and more about meaning, and while Fennario's intention is interesting, that people frequently referred me to his work to get a sense of Point Saint Char les is telling in itself. ${ }^{24}$ These works are fundam ental for their $\mathrm{c}$ ontribution to the public $\mathrm{m}$ emory. Balconville, a bilingual play set in Point Saint Charles and widely lauded as authentic by residents, hints at language tensions and the st ruggles of a population in the midst of deindustrialization. Joe Beef: A History of Point Saint Charles links Beef with The Point, firmly situating him in his role as working-class hero. Here, Fennario uses him m uch in the sam e way the PSC Community Theatre does, as the entry poi nt into the class a nd labour history of Point Saint Charles. In this, Joe Beef offers a window through which Point residents can "see" the early and ind ustrial history of The Point. Beef is used to es tablish class values from the valiant Lachine Canal strikers, and thus the working-class, who sacrificed even food for fai rness, to Montreal's upper clas ses from whom wealth $\mathrm{m}$ eant more than people.

Fennario is not the only history $\mathrm{m}$ aker of importance to the public memory of Point Saint Charles. Parks Canada, with its preservation of the Lachine Canal, and the Société d'histoire de Pointe-Saint-Charles (SHPSC) has contributed heavily to this constructed version of the past. In addition to the Joe Beef Market, the SHPSC organizes walking tours, hosts special exhibitions, publishes regular newsle tters, agitates for preservation of local heritage sites, and creates inform ational history $\mathrm{m}$ arkers. These formalized and public sources present a seemingly official version of Point Saint Charles' past and are telling in their selections and silences. They typically focus on either the

\footnotetext{
${ }^{22}$ David Fennario, Joe Beef : A History of Pointe Saint Charles (Vancouver: Talonbooks, 1991).

${ }^{23}$ David Fennario, Balconville, 1st ed. (Alexandria, VA: Alexander Street Press, 2007).

${ }^{24}$ For example, Rita Walters, interview by Jessica J. Mills, December 2, 2008.
} 
pastoral or industrial period of The Point, offering an uncomplicated view of the past infused with what Steven High and David Lewi s refer to as "“smokestack nostalgia' - an empty lament for lost industry that assumes unity, and silences conflict and resistance."25

Nostalgia offers additional insight into aspects of place and pe rsonal identity, and changing material practices. Peter Fritzsche argues that because it depends on a notion of historical process, nostalgia is a m odern phenomenon with a strong narrative dim ension and suggests we need to "reconsider nostalg ia not as blindness but as sightfulness". ${ }^{26}$ As High and Lewis point out, nostalgic responses "are more likely to confirm notions of progress rather than to subvert them "27 Many of the narra tives about The Point a re steeped in loss and centred on change that is seen as inevitable:

Nostalgia can, conveniently but arbitrar ily, be described as selectively remembering the past in a way that suppor ts a negative evaluation of the present situation and displays the past positively as a coherent, comprehensible era. ${ }^{28}$

At the same tim e, due to its ve ry nature, nos talgia helps to solid ify the cre ation of a “community of memory".

Social media can pro vide a po werful access point fo $r$ assessing nostalgic undertones and gauging people's attachment to place. Sev eral Facebook groups have been created for Point Saint Charles and lar ge numbers of people are participating in these arenas where community identity is being built, revised, agreed upon, and

\footnotetext{
${ }^{25}$ This is after taking into account High and Lewis' warning that dismissing something as smokestack nostalgia could be a means of discrediting working class voices and/or culture, Steven C High and David W Lewis, Corporate Wasteland: The Landscape and Memory of Deindustrialization (Toronto: Between the Lines, 2007), 94.

${ }^{26}$ Peter Fritzsche, "Specters of History: On Nostalgia, Exile, and Modernity," American Historical Review 106, no. 5 (2001): 1592.

${ }^{27}$ High and Lewis, Corporate Wasteland, 60.

${ }^{28}$ Talja Blokland, "Bricks, Mortar, Memories: Neighbourhood and Networks in Collective Acts of

Remembering," International Journal of Urban and Regional Research 25, no. 2 (6, 2001): 272.
} 
solidified. ${ }^{29}$ Groups generally have a section with pictures, a discussion board listed by topic, as well as a "wall" where peo ple post information or make comments. There is richness and reflection in the shared $\mathrm{m}$ emories and the in teraction between members. These forums are active places, $\mathrm{v}$ isible to everyone, where sim ple group m embership allows one to post with lim ited moderation. Groups are divided lingui stically, hinting at some of the tensions and divisions in th e neighbourhood. "The Point website", found at thepoint.ca, is another space for emerging communal memories. The site advertises local events, has a section for photos, and of fers a moderated "guestbook" where people post information and share in discussions. ${ }^{30}$

These rich narrative sources of fer unique perspectives - few of the $\mathrm{c}$ ontributing members still live in Point Saint Charles. Posts on Facebook start by asserting how much the writer loves and misses The Point since leaving and thepoint.ca contains a guestbook field marked "Where are you From". The majority of entries include Point Saint Charles before listing another city, a clear indicati on of mobility and connection to place. This distance lends a nostalg ic influence to the nar ratives. After all, the te rm nostalgia was coined to "describe a painful yearning to return home". 31

Within these sites former residents reminisce about the good old days of The Point

\footnotetext{
${ }^{29}$ The Facebook group 'Point Saint Charles 'The Point'" has 1035 members and is fairly active in its posting and readership. "PSC born and raised" has 418 and the "Pointe St Charles" group has 1028. "Point Saint Charles "The Point"," www.facebook.com, The Point....As WE all know it!!!, http://www.facebook.com/group.php?gid=2258791996\&ref=ts\#!/topic.php?uid=2258791996\&topic=2594; "POINTE ST-CHARLES," www.facebook.com, http://www.facebook.com/\#!/group.php?gid=50293771335; "PSC born and raised," www.facebook.com, http://www.facebook.com/\#!/group.php?gid=2364709526., Accessed, October $19^{\text {th }}, 2010$.

${ }^{30}$ The first version of the guestbook was removed due to its inability to be moderated. Since its inception in 2006 there has been 3860 entries in the the second version of the guestbook. "Thepoint Guest Book," thepoint.ca, http://www.websitetoolbox.com/tool/gb/gwmcrae.Accessed October $19^{\text {th }}, 2010$.

${ }^{31}$ James Overton, "Coming Home: Nostalgia and Tourism in Newfoundland," Acadiensis 14, no. 1 (1984): 84.
} 
and lament that nowhere else feels like hom e. ${ }^{32}$ Many of the online contributions center on childhood memories nuancing the nostalgic influence. Though writing on Newfoundland, Sociologist James Overton's reflections are equally valid in The Point:

The golden age vision is a kind of utopi a. It is less a description of Newfoundland than an expression of current alienation and a longing for a more satisfying life. Elem ents from people's pasts are being incorporated into the vision, however, especially childhood memories, childhood being for $\mathrm{m}$ any something of a golden age of innocence compared with adult life. ${ }^{33}$

Often the o nline narratives reflect what Fr ed Davis wo uld call simple nosta lgia: a subjective state that remains unexamined infuse $d$ with a warm glow and the idea of lost values. ${ }^{34}$ It also creates a yearn ing to return and "returning migrants themselves have a profound effect on the local scene and lo cal conceptions of their community., 35 Geographer, Toby Butler suggests that as popu lations change, the st ories tend to com e from those who have rem ained. This gives an impression of stability that might not actually exist. ${ }^{36}$ In context of The Point th is can be extended to include those who despite their absence, still ac tively engage with the $\mathrm{p}$ lace, their co mmunity and the memory of its pas t. This selectivity is problematic; the online na rative of Point St Charles's past is in reality a reflection of the present and the people who have maintained a presence, even if it is only virtual, within the community.

This thesis consists of three chapters that use these sources in varying ways. In chapter 1 entitled "Placing The Point", we w ill follow the shifting temporal and spatial understandings of place and explore the fluid nature of The Point's symbolic and physical

\footnotetext{
${ }^{32}$ For example, see, "Point Saint Charles "The Point"," www.facebook.com, http://www.facebook.com/\#!/group.php?gid=2258791996.

${ }^{33}$ Overton, "Coming Home," 88.

${ }^{34}$ Fred Davis, Yearning for yesterday: A sociology of nostalgia (Free Press New York, 1979), 19-20.

${ }^{35}$ Overton, "Coming Home," 92.

${ }^{36} \mathrm{~T}$. Butler, "Memoryscape: how audio walks can deepen our sense of place by integrating art, oral history and cultural geography," Geography Compass 1, no. 3 (2007): 44.
} 
boundaries - how they cam e to be and how th ey inform public history and the use of community. Sociologist Sharon Zukin states th at "landscape represents the architecture of social class, gender, and race re lations imposed by powerful institu tions. ${ }^{, 37}$ We will explore the meaning ascribed to $\mathrm{p}$ lace as a result of several of these processes, and examine how these factors contribute to place attachment and the rise of activism in The Point.

In chapter 2, entitled "Bringing Class Back to The Point", we shift our focus to situate the tension associated with gentrification within the history and class rela tions of Point Saint Charles. We will examine how the public memory of industrialization and industrial decline contributes to a class homogenous memory of The Point and explore how this memory is being threatened by so cio-economic change that does not fit the traditional model of gentrification.

In the final chapter, entitled "Putting the Unity in Community", we will examine a "community of m emory" and question how and why "Pointers" are sm oothing out conflicting memories, and silencing dissent wi thin the group, while asserting dif ference from "others". We explore how the construc tion of this comm unity is influenced by place attachment and class positioning, a nd how it represents a struggle over place identity made manifest by gentrification.

Together, this thesis traces the s hifting meaning behind place, class, and community in The Point. Here we witness how history and memory offer insight into the present day processes of urban chan ge. We see how notions of place can contribute to a rhetoric of stability that pos itions the cu rrent change as the greatest threat yet, and

\footnotetext{
${ }^{37}$ Sharon Zukin, Landscapes of Power: From Detroit to Disney World (Berkeley: University of California Press, 1991), 16.
} 
analyze how these fe ars are grounded in previous periods of urban renewal and displacement that The Point has contended with in the past. We observe how class-based identity has become inscribed on $\mathrm{T}$ he Point an $\mathrm{d}$ how it is used as the keystone in the creation of a comm unity of "P ointers" who $m$ ay or $m$ ay not still live in Point Saint Charles.

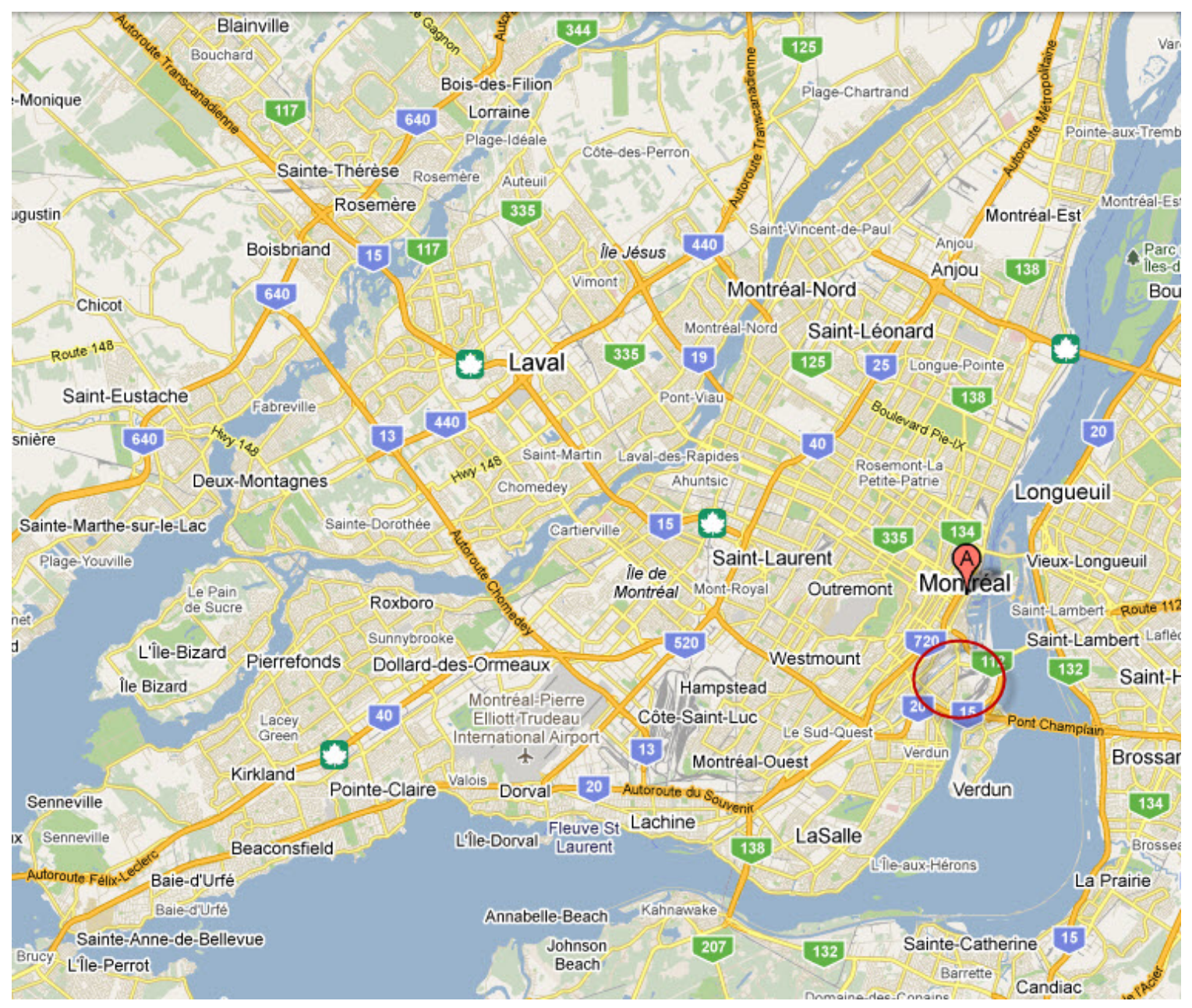

Map 1. 1: Map of Point Saint Charles within the island Montreal. The area is denoted by the circle. Source: Google Maps, (C) 2011. 


\section{Chapter 1: Placing The Point}

The present-day boundaries of Point Saint Charles are marked by a series of signs reading "Les velos dovient revenir au Poin t", remnants of a free neighbourhood bicycle sharing program that no longer exists. Launc hed in 2009 by the Centre Social Autogéré, the project placed bicycles in various locations around The Point for use by its residents. Riders could pick up a bike at any of the st ands and return it to any other with in the district. The signs - located on Wellington, at its eastern edge, just prior to passing over the canal, on its western edge, before crossing into Verdun and imme diately before the bridges that cross over the canal into either St Henri or L ittle Burgundy - remind riders that the bicycles are to remain in The Point. The signs make the boundaries of the district seem stable, yet they have been anything but.

In The City Below the Hill, Herbert Brown Ames attempted to undertake what he deemed "a sociological study of a portion of Montreal," $\quad 38$ examining working class Montrealers in 1897. Ames' study went as far s outh as Centre Street, a street that still runs through Point Saint Charles. His reasoning was that:

[b]eyond Centre street lies that special di strict of Point St. Charles, which is almost an independent suburb by itsel $f$, being sustained by e mployment furnished in the offices and workshops of the G.T.R. [Grand Trunk Railway]. ${ }^{39}$

Ames' definition of Point Saint Charles contradicted others written at the time and even since, the geo-spatial definitions of The Point have varied widely. For exam ple, a map from 1859 has the lim its of Point Saint Charle s as far north as St. Joseph Street and defines its western edge as cutting the curr ent conception of the neighbourhood in half. By contrast, a City of Montreal $\mathrm{m}$ ap published in 1881 sees the northern boundary of the

\footnotetext{
${ }^{38}$ Herbert Brown Ames, The City Below the Hill: A Sociological Study of a Portion of the City of Montreal, Canada, Social history of Canada (Toronto: University of Toronto Press, 1972).

${ }^{39}$ Ibid., 8.
} 
Point as the Lachine $\mathrm{C}$ anal, but otherwise te nds to restrict the are a to a few streets directly adjacent to the Grand Trunk Railway workshops. The western half of Point Saint

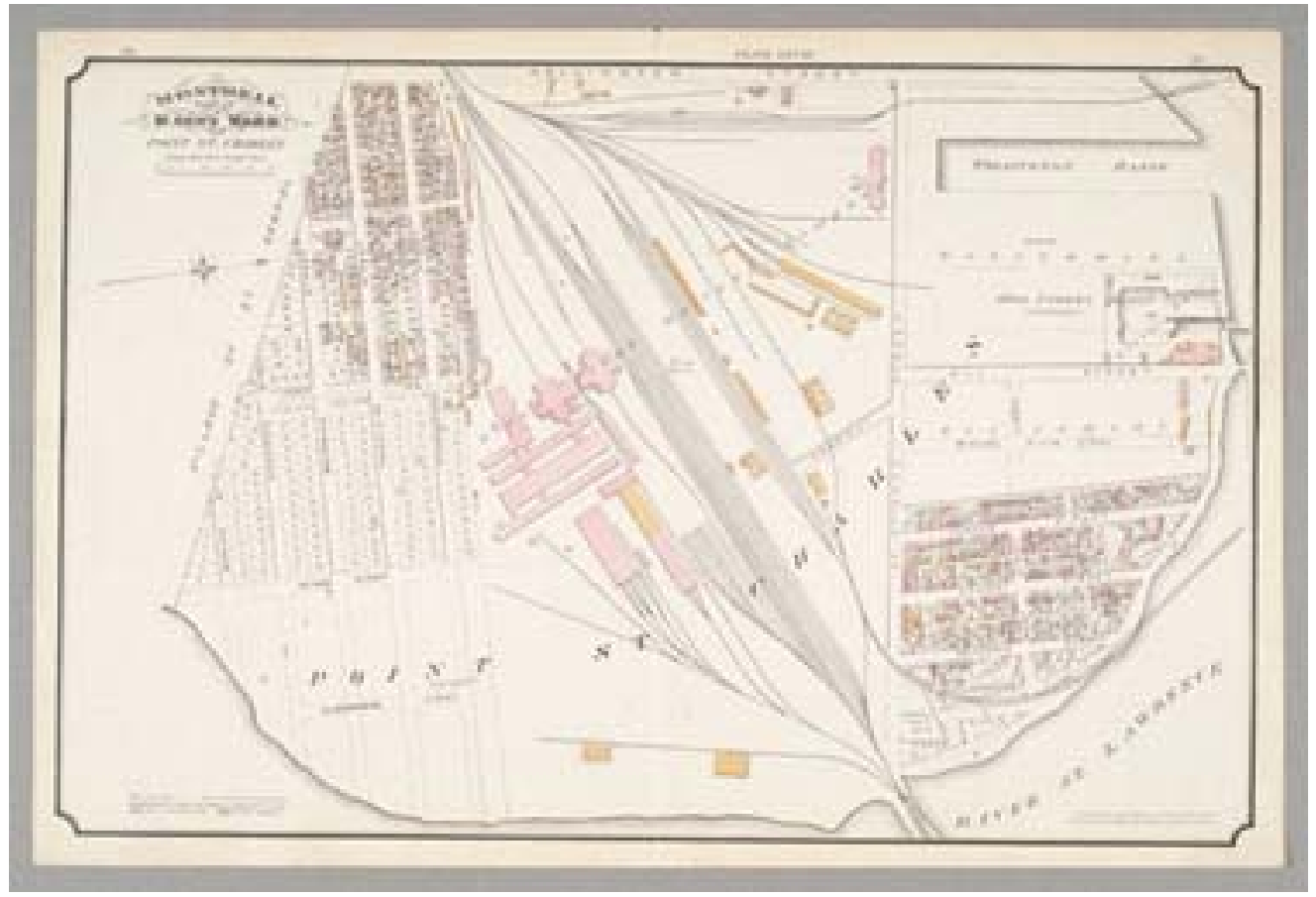

Map 2. 1: Point Saint Charles as identified in the "Atlas of the City of Montreal, 1881. Source: Bibliothèque et Archives nationales du Québec

Charles used to be known as St. Gabriel's Village while the eastern half was considered a part of St. Ann's Ward, complicating the earliest history of the built environment of the district. Other $\mathrm{m}$ aps depict a Point Sain $\mathrm{t}$ Charles with fluid and uncertain boundaries produced by multiple conceptions of place. Its c ontested nature reminds us that "places as depicted on maps are places caught in a moment; they are slices through time." ${ }^{\circ 0}$ Also varied, more recent views of Point Saint Char les call for a deeper 1 ook at how place is created, how it is used, and what it means to those who identify with it.

\footnotetext{
${ }^{40}$ Doreen Massey, "Places and Their Pasts," History Workshop Journal, no. 39 (April 1, 1995): 188.
} 
The problem with defining place, as so aptly pointed out by Doreen Massey, is that "the past of a place is as ope $n$ to a m ultiplicity of readings as is the pre sent" Examining the shifting boundaries of Point Sa int Charles over time demonstrates that we must look beyond the 'official' definition of this place - if one could be agreed upon - i f we are to begin to understand the varying $\mathrm{m}$ eanings attached to The Point. The act of creating place and ascribing meaning is multifaceted and thus difficult to comprehend in its entirety. However, we can get a sense of how this process works through the ways in which residents describe their Point Saint $\mathrm{Ch}$ arles and the public s ources about it. Activities organized by $\mathrm{m}$ any local groups contain place-making elements: maps are created, literature is circulated, and gentri fication is con textualized all within the framework of place, drawing on m eaning that might not be shared. These ideas of place in turn help define the many communities hous ed within. These elements come together in the way stakeholders present the past, fight for the present, and attempt to secure the future, of the place they see as important.

If we are to understand what $\mathrm{m}$ akes a place worth fighting for, then we need to tease out $\mathrm{w}$ ays in which $\mathrm{m}$ eaning is create d. J.B. Harley ar gues that $\mathrm{m}$ aps create knowledge and assert power. To understand them, we must look at the context in which they are created and how they are being used. ${ }^{42} \mathrm{He}$ furthers that $\mathrm{m}$ aps "are regarded as refracted images contributing to dial ogue in a socially constructed world." ${ }^{43}$ Maps of Point Saint Charles are frequently produced, either informally or by hired cartographers, by the community or ganizations that require them. These maps differ depending on the

\footnotetext{
${ }^{41}$ Ibid., 185.

${ }^{42}$ Harley, J.B., "Maps, knowledge, and power," in The Iconography of Landscape: Essays on the Symbolic Representation, Design, and Use of Past Environments, ed. Denis E Cosgrove and Stephen Daniels, Cambridge studies in historical geography 9 (Cambridge [England]: Cambridge University Press, 1988).

${ }^{43}$ Ibid., 278.
} 
context that necessitated their production. The Point Education Improvement Committee (PEIC) was a lar gely English institution that aimed, among other initiatives, to im prove the education of Anglophone students in the area by introducing topics to the curriculum that would resonate with inner-city youth. To this end, it created a module addressing the history of the streets of Point S aint Charles and solicited involvem ent through a community walk. ${ }^{44}$ The resulting map, accompanied by a questionnaire, shows only the southern section of Point Saint Charles. This area, divided from the rest of The Point by railway tracks, has lar gely housed the Anglophone population. It is telling that the PEIC's attempts to interest youth focused on a place that it perceived as im portant and connected to the intend ed audience. In th is way, the hand-drawn m ap that accompanies this module can be seen as the socially-constructed knowledge that Harley put forward.

The module's associated questionnaire requ ired participants to provide answers about the map, and then to personalize it. The choice of questions reveals the $\mathrm{m}$ eaning behind certain places and the module's intended audience. In particular, users responded to clues that corresponded with numbers on the map. Requests ranged from "which bus goes along this street?", "what company is located on this spot?", "what language do they speak in this school?", "what is the name of this farm?" to "what city is on the other side of the railway line?" referring to neighbouri ng Verdun. This module provides a window into transportation networks, linguistic diversity, the economic environment, the pastoral history of the area and the separation from adjacent districts. In the second section, participants are asked to "put an A on the place where [they] live", to identify their school, the community clinic, the Centennary Church and the St Lawrence River and

\footnotetext{
${ }^{44}$ Point Saint Charles Education Improvement Committee, "Community Projects: Community Walk," MG 4263, Acc. 2008-0024, McGill University Archives.
} 
finally to name the boundaries as marked on the map. By denoting the streets that are the farthest north, east and south, th is module is helping define a nd create the place that is meaningful to the residents that would use it. If maps create knowledge, than the PEIC's students are learning about their place in The Point.

So then, what are residents of Point Saint Charles being taught with contemporary maps of the area? Maps of Point Saint Charles vary in detail, but in the vast majority the district is without context; rarely is The Point visually situated on the Island of Montreal. A few maps denote adjacent neighbourhoods by name, but otherwise, there is little detail. One of the Carrefour d'educat ion populaire's most frequently used $m$ aps shows a birdseye view of the area, created to scale, with the built environment detailed. ${ }^{45}$ Others show only streets or even reduce the streets to the $m$ ain arteries of The Point. The implication here is clear; Point Saint Ch arles stands on its own. In a ddition, most maps are situated in the pres ent, regardless of the time period to which they ref er. These tend to us e the current definitions of Point Saint Charles even when referencing periods where, as we've seen, the borders of this area were unclear. A booklet, entitled "A Brief History of the Streets and Parks in Point Saint Charles", publ ished by the Société d' histoire de PointeSaint-Charles, is a good exam ple. ${ }^{46}$ Currently in its third edition this booklet is sold in English or French, at community events or by the SHPSC itself. The two maps found in the booklet show the current conception of The Point. The first, found under the heading "Neigbourhood Map", predictably cuts the area off from the larger urban context. The second using alm ost the sam e image, only shows areas of su rrounding boroughs that

\footnotetext{
${ }^{45}$ Le Carrefour d'education populaire, "Pte-Saint Charles,” MG 4263, Acc. 2008-0024, McGill University Archives.

${ }^{46}$ Société d'histoire de Pointe-Saint-Charles., A Brief History of the Streets and Parks in Point Saint Charles, 3rd ed. ([Montréal]: Éditions Histoire Québec, 2009).
} 
contained portions of the founding farm s of the area. Both of these maps, like the others that can be found, reinforce a notion of $\mathrm{pl}$ ace that appears unchangin $\mathrm{g}$, solidifying a conception of stability and reinforcing the idea that change in the present is a threat to the meaning of the place.

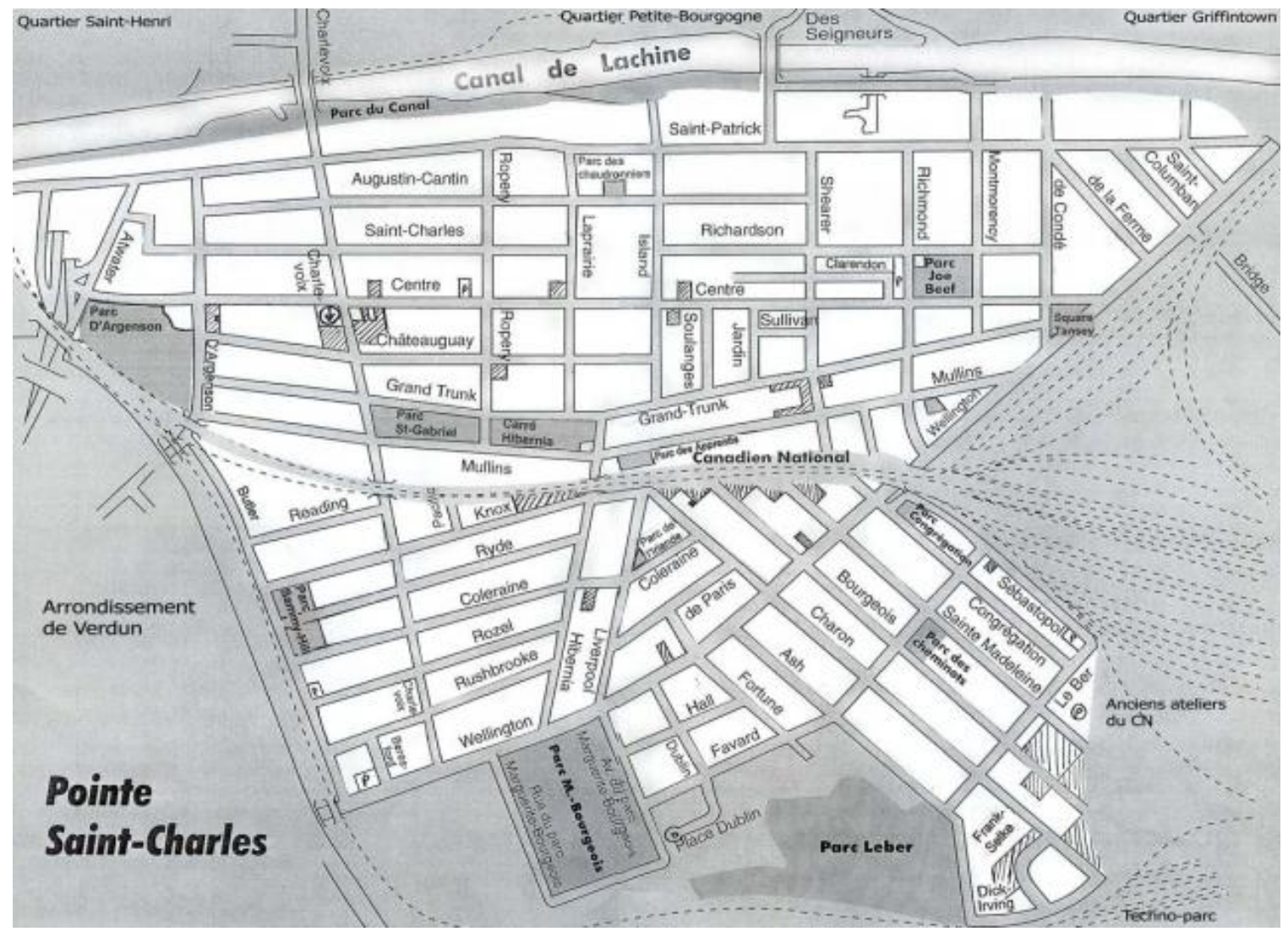

Map 2. 2: Pointe Saint Charles. The neighbourhood is presented without context. Source: La Pointe Libertaire

A perception of change in the present is determined by an awareness of the past. These maps also serve as rem inders of the history of Point Saint Charles ' built beginnings, but they are not the only way pe ople can read the past of place. Early construction in The Point began with s everal farms, run mostly by religious orders. Priests from the Society of Saint Sulpice were among the first to settle in the area, establishing the St. Gabriel Farm, commonly referred to as the Priest's Farm, in 1657 in 
what is now the northern boundary of Poin

Bourgeoys, a Catholic nun and educator, obtained a concession from Paul Chomedey de Maisonneuve, one of M ontreal's founders, which allowed her to purchase a farm and a stone house from Francois Le Ber and establish a presence in the area. This house, built in 1698, still stands in Point Saint Charles, and is currently used as a living history museum. ${ }^{47}$ Once called La Providence, it has been renamed Maison Saint Gabriel, likely in homage to the Order of the Sulpicians. ${ }^{48}$ These roots are present in the available public history, and reinforced by physical rem inders. As its website te lls us: "Maison S aintGabriel is the home where the King's Wards were housed and, for alm ost 300 years, the farmhouse for the Congrégation de Notre-Dam e." ${ }^{49}$ The area rem ained pastoral and largely unpopulated for the first couple hundred years; in the early nineteenth century the population of Point Saint Charles only num bered approximately 200 people. $^{50}$ Doreen Massey reminds us that "the past may be present in the resonance, whether actually from the past or reinserted as a self-cons cious building-in of 'local character", 51 and much of this religious and agricultural past lays claim to the pres ent in the form of street names and parks. The Société d'histoire de Pointe Saint Charles also privileges this period in the Point's history, organizing events and ultimately attempting to recapture the places of this past. For exam ple, it succeeded in maintaining "Rue de la Ferm e," which follows the

\footnotetext{
${ }^{47}$ There is some variation in the dates offered by the sources. Variation might be attributed to different phases of construction. See, Jean Claude Marsan, Montreal in Evolution: Historical Analysis of the Development of Montreal's Architecture and Urban Environment, 1st pbk. ed. (Montreal: McGill-Queen's University Press, 1990)."Société d'histoire de Pointe-Saint-Charles," http://www.histoirepointesaintcharles.org/histoire.html.; "Maison Saint-Gabriel, située près du Vieux-Montréal, Montréal, Québec, Canada," http://www.maisonsaint-gabriel.qc.ca/index.html.

48 "Société d'histoire de Pointe-Saint-Charles.", accessed April 1, 2010

49 "Maison Saint-Gabriel, située près du Vieux-Montréal, Montréal, Québec, Canada.", accessed April 1, 2010

${ }^{50}$ Kruzynski and Drolet, The Point Is-- Grassroots Organizing Works, 26.

${ }^{51}$ Massey, "Places and Their Pasts," 187.
} 
path of the original road th at ran to St Gabriel's Farm. Although this route now passes through privately held industr ial lands, pedestrians walkin g on Wellington can find an informational signpost that lays out this history. In the end, Rue de la Ferm e, joined by, Bourgeoys, Knox, de La Congregation, and Le Ber Streets and Mar guerite Bourgeoys Park, stand as physical rem inders of this er a. By association, people have rem embered and incorporated this past into their notions of place.

While The Point's early past is inscribed on place by physical reminders, there are broader changes that are etch ed into the landscape. The boundaries that surround places are frequently fluid, but those that edge The Point are unique; they $\mathrm{h}$ ave been shifting physically while solidifying symbolically. The Southern boundary, along the St Laurence River has been pushed further into the river with time. Shoreline changes started in 1933 and continued as late as 1980, however the lar gest change cam e in 1966 whe $\mathrm{n}$ dirt excavated during the construction of the Montreal Metro system was trucked in. ${ }^{52}$ The former swamp-land, once prone to flooding, is now solid ground but the expansion of the shoreline is remembered in The Point for another reason. While currently known as the Pointe Saint Charles Technoparc, and site of the Bonaventure Expressway, this was once an open garbage dum $\mathrm{p}$, for both residential and industrial waste. It was here that the children of The Point played. On a Face book group, Rod Young remembers: "playing in Maggie Bougy park [the nam e often given to Margaret Bourgeoys Park] and the dump behind there". 53 This was listed, among several others, as one of the things that made the Point special to him. Even Denis Smyk speaks fondly of his time playing in the dump:

\footnotetext{
${ }^{52}$ G R, "Historique du rivage, ancien depotoir Pointe Saint-Charles, Montreal" (Fitzpatrick Canada Limitée, February 23, 1999), Archives Société d'histoire Pointe Saint Charles.

${ }^{53}$ Rod Young, "Point Saint Charles "The Point"."
} 
"[Immediately] after the tracks there was dump, from Victoria Bridge to Champlain Bridge was just one big dum p, so we used to go there to shoot rats and shoot seagulls, start fires and do all sorts of mischief there... it was a play area. $" 54$

While the water's edge has changed, it has re mained the southern boundary line of The Point. Though much of this land is undeveloped, place is solidified thorough these memories and the boundary known by experience. The Point's Western border was made manifest by the building of the Bonaventure Expressway in the 1960s, clearly separating it from neighbouring Verdun. Only a few streets cut under the auto route. These lines are certain, visual, and seemingly stoic. They are the first few walls of the fortress.

The most visible boundary, and perhaps th e greatest physical reminder of Point Saint Charles' past, is the Lachine Canal, an artificial waterway that divides it from the remainder of the island. When originally proposed, the route of the canal ran through land further north. When the cost prove d prohibitive, the comm ittee, following the initiative of John Richardson, opted for a m ore southern route along the Turnpike, which would bring it through farmland that belonged to the Order of the Sulpicians. Completed in 1826 , the construction of th e canal created the current $\mathrm{p}$ hysical delineation of Point Saint Charles, establishing its northern and eastern boundaries. In the strictest geographical sense of place, the Point woul $d$ not be $w$ hat it is to day without the construction of the canal. Point Sa int Charles is currently define $\mathrm{d}$ by its edges. The canal's subsequent enlargements, and resulting industrialization, had no less of a dramatic impact on the landscape of The Point. ${ }^{55}$

\footnotetext{
${ }^{54}$ Denis Smyk, interview by Jessica J. Mills, October 28, 2008. Montreal: Quebec

${ }^{55}$ Gerald J. J Tulchinsky, The Construction of the First Lachine Canal, 1815-1826 (McGill University, 1960), 4.
} 
The Lachine Canal reinforces the meaning behind place, first by giving The Point yet another firm border and then as a storehou se of memory. The Lachine Canal, and its hydraulic power, was the catalyst for industr ialization, which, in turn, provided the impetus for the founding of The Point. With the goal of widening the canal and reducing the number of locks, work began afresh on the Lachine Canal in 1841. American engineer Alfred Barrett "insisted on the development of [...] hydraulic potential, going so far as to $\mathrm{d}$ esign the necessary structures - $\mathrm{h}$ eadraces, tailraces and water sup ply channels". ${ }^{56}$ As residents are often rem inded, this is the most important aspect of the Lachine Canal's construction; The Parks Canada website highlights that "the exploitation of hydraulic power from Basin No. 2 and th e Saint-Gabriel sector ... stim ulate[d] substantial investments within a few years in about thirty businesses, several of which were completely new." ${ }^{57}$ Com panies took advantage of the power source and the government was given "an opportunity to recoup its investment by leasing rights to the surplus water." 58 Industries were a "mix of both heavy and light producers, ranging from chemicals to rolling stock to food and beverages." 59 Denis S myk explains The Point's development as follows:

Because of the available cheap ener gy of the canal, the proximity to the port and the $\mathrm{CN}$, at that time it was called Grand Trunk Railway, they set up there, so they needed workers, so the municipal authority decided to allow streets to be cu t through here so that houses could be built to get workers to feed these industries. ${ }^{60}$

\footnotetext{
${ }^{56}$ Desmond Andrew Bliek, "Reweaving Urban Fabrics: Urbanisation, Industrialisation and Regeneration in Southwest Montréal" (Concordia University, 2007), 51.

57 "Parks Canada - Lachine Canal National Historic Site - The Cradle of Industrialization," July 15, 2009, http://www.pc.gc.ca/eng/lhn-nhs/qc/canallachine/natcul/natcul2/c.aspx.

${ }^{58}$ Bliek, "Reweaving Urban Fabrics," 51.

${ }^{59}$ Alain Gelly, "A Precipitous Decline, Steam as a Motive Power in Montréal: A Case Study of the Lachine Canal Industries" Industrial Archeology, 29-1 (2003): 65

${ }^{60}$ Smyk, interview.
} 
Many sources follow an assessm ent that transforms farms to factories. ${ }^{61}$ Im portantly, industrialization was aided by the ongoing transition from the seigneurial system toward pro-capitalist forms. The Sulpician Seminary of Montreal had twenty years, beginning in 1840, to dispose of the seigneurial landholding s, including the Sain $t$ Gabriel property through which the canal ran. ${ }^{62}$ John Redpath, for instance, made arrangements to buy the land next to Priest's Basin from the Seminary of St. Sulpice for his sugar house, soon to become one of the new industrial firm s. ${ }^{63}$ The Grand Trunk Railway Workshop, which became one of the area' s largest employers, was built in 1854 and the Victoria Bridge, considered a marvel of engineering, was completed in 1859.

The Lachine Canal do es not just lie as a reminder, it is a lso interpreted. Parks Canada offers boat tours and a variety of or ganizations offer a number of self-guided and group walking tours. N ot surprisingly, the Société d'histoire de Pointe Saint Charles is responsible for a large amount of the information that is presented about these periods; it tends to shy away from twentieth century hi story. On its w ebsite, under the heading la petite histoire du Pointe Saint Charles en br ef, a short text is intersp ersed with images. After stating that the banks of the Lachine Canal were the cradle of industry in Canada, the explanation finishes with:

Une vague d'Irlandais, chassés par la fa mine, déferlent alors sur les grèves du canal. Ils seront la grande force motrice de $\mathrm{s}$ a réalisation et de celle du Pont Victoria, considéré en son temps comme la huitième merveille du monde! Plus tard, viendront les Polonais et les Ukrainiens, faisant de Pointe-Saint-Charles le premier quartier ethnique de Montréal. Les maisons actuelles de Pointe-Saint-

\footnotetext{
${ }^{61}$ See, for example, Société d'histoire de Pointe-Saint-Charles., A Brief History of the Streets and Parks in Point Saint Charles; Fennario, Joe Beef; "Société d'histoire de Pointe-Saint-Charles."

${ }^{62}$ Bliek, "Reweaving Urban Fabrics," 54.

${ }^{63}$ Richard Feltoe, Redpath: The History of a Sugar House (Toronto: Natural Heritage/Natural History, 1991), 23.
} 
Charles furent construites sur les terrai ns appartenant aux Sulpiciens et aux Soeurs de la Congrégation de Notre-Dame. $[\text { sic }]^{64}$

In essence, what creates meaning and forms the locality - from religious farms to major changes in inf rastructure - is envis ioned, orchestrated, built and f inanced by global participants, French, Irish, Scottish, American and English among others. Like Massey's Kilburn High Road it is im possible to think of The Point without linking its construction to countries all over the world which "provokes in you (or at least in me) a really global sense of place...". ${ }^{65}$ Yet the global roots of its $\mathrm{f}$ oundation have been appropriated by residents and $\mathrm{m}$ ade local. The web of in ternational connection is inscribed on the landscape. Often, the physical engages the whole of The Point, as it did with the Lachine Canal. Sometimes the reminders are specific. Currently on the median of Bridge Street, in the shadow of a Cost co consumer warehouse, sits the Black Rock, destination of an annual memorial march by the Ancient Order of Hiberians. As the Irish imm igrants fleeing the Potato Fam ine often arriv ed in Montreal ill with ty phus, they were quarantined in terrible conditions. Approximately 6000 died, along with several caretakers. Not surprisingly, this memorial is an important commemorative site for the local Irish community. The Irish memory of The Point, and the community that houses it, is in itself unique, and unfortunately beyond the scope of this study. However, because of the inscription, which reads " $[\mathrm{t}] \mathrm{o}$ preserve from desecration the rem ains of 6000 immigrants who died of ship fever A.D. 1847-8. This stone is erected by the workmen of Messrs, Peto Brassey and Betts, employed in the construction of the Victoria Bridge A.D. 1859," the Black Rock has been in corporated into the history of this place, as a way to remember the Irish immigrants who died upon arrival to Canada, and the Irish roots of

\footnotetext{
64 “Société d'histoire de Pointe-Saint-Charles.", accessed May 23, 2010

${ }^{65}$ Doreen Massey, “A Global Sense of Place,” Marxism today 35, no. 6 (1991): 27.
} 
the neighbourhood. Of utm ost importance in Irish memory, the Black Rock, still speaks to other Point Saint Charles residents; it too stands in testament of the construction of the Victoria Bridge.

Indicators of industrialization, like The Victoria Bridge, are important, not only because they help create place. The memory of industrialization is fundamental in the construction of a "constitutive nar rative". 66 The creation of Point Saint Charles as th e cradle of industry is unifying and empowering fo $\mathrm{r}$ its residents, especially given that the early part of this history is lar gely beyond living memory and therefore resists some of the immediate potential to be conflicted, contested, and challenge d. There is obvious pride in the public history sources that detail the industrial period. The second annual Joe Beef market honoured John Richardson for his role in the Lachine Canal and the third featured Thomas Keefer, who designed the sup ports for the Victoria Bridge and selected its location. This past is rep lete with expressions of ownership of The Point's, and by association Montreal's, industrial past:

On dit de Pointe-St-Charles que c'est le berceau de l'industrialisation as Canada. C'est presque vrais, par 2 années. En fait, les premiers lots hydraulique à voir le jour, et donc le premier vrai parc industriel à être créé au pays, le furent en 1848 aux écluses de la Pointe-des-Moulins, sur la rue Mill, face à Griffintown. Mais en trichant un peut presque dire que c'est Pointe-St-Charles. ${ }^{67}$

The Point differs from single industry towns, such as Sturgeon Falls ${ }^{68}$ and Youngstown ${ }^{69}$, upon which Linkon and Russo based their concept of constitutional narrative; references to things like "our mill" do not ring out with such frequency. Rather than being industry or company specific, The Point claims the whole Lachine Canal, with figures lik e Joe

\footnotetext{
${ }^{66}$ Linkon, Steeltown U.S.A, 4.

${ }^{67}$ Société d'histoire Pointe Saint Charles, "Handouts - D'ateliers sur l'histoire du quartier et des environs," February 14, 2009.

${ }^{68}$ High and Lewis, Corporate Wasteland.

${ }^{69}$ Linkon, Steeltown U.S.A.
} 
Beef and the strike as a prim e example. This ownership, infused with $\mathrm{m}$ eaning, helps create and reinforce place and depends on an awareness of the transformative change that industrialization brought to the physical environment.

The Lachine Canal, and its early $r$ ole in shaping The Point, continues to im pact residents and their socially constructed sense of community and place. The canal was an integral part of life in The Point. Its adjacent mills and factories provided jobs, which in turn supported the residential development of the area. Its presence was constant:

Our school was one block from the can al so you'd see the $\mathrm{m}$ asts going past behind the buildings and you know the guy's blowing the ho rn because they're going to be opening the bridge, they wanted them to open the bridge down there, so the teach er's trying to talk and a 11 you hear is lik e 'brrrrrrrr' the fo $g$ horn blowing you know what Im ean. At day and at night. I remember in the summertime lying in my room trying to sleep, it was hot, the windows were wide open and you'd hear these boats 'brrrrrrr'

The opening of the Saint Lawrence Seaway in 1959 and the partial closing of the Lachine Canal in $1960 \mathrm{~m}$ arked the end of the i ndustrial period in Point Saint Charles. ${ }^{71}$ The impact of the canal is no less in its new in ception as a "leisure space". The Lachine Canal is se en as the catalyst for change in Point Sain t Charles a nd is $\mathrm{f}$ requently referenced as such: "the Point is changing, for the same reason it came into being in the first place. The canal. ${ }^{, 72}$ The rise, fall, and reinven tion of the Lachin e Canal $m$ irror changes in Point Saint Charles itself, nam ely its creation, the area 's decline, and its current gentrifying character. The canal is symbolic as well as physical. In this $\mathrm{m}$ anner, it is a good exam ple of how "a social group or system produces a wide range of spatial

\footnotetext{
${ }^{70}$ Smyk, interview.

${ }^{71}$ Among others, Kruzynski and Drolet, The Point Is-- Grassroots Organizing Works, 29.

${ }^{72}$ Cleo Paskal, "Tough but caring: That's the Point," The Toronto Star, April 21, 2007, http://www.thestar.com/article/204543.
} 
markers and sym bols that reflect som e embeddedness in lar ger historical system s of power., ${ }^{, 73}$

While the Point's boundaries are physical in construction, they have collectively become symbolic in nature; the phy sical divide has become a tangible way for residents to differentiate themselves from their neighbo urs. These boundaries are accep ted as having created stronger cohesion in The Point than elsewhere, largely because intra-urban travel is impeded by them. These barriers also played, and continue to have, a major role in the identities of residents and outsiders:

The cohesion of this neighbourhood is unusual. Surrounded by water and railway tracks the neighbourhood is locked in by physical obstacles. These undoubtedly create a psychologi cal barrier between Poin t St. Charles and the rest of Montreal. ${ }^{74}$

This idea of inaccessibility grew with the area, reinforced by the physical barriers that surround the territory. There is no doubt that th e Point is separated from the rest of the Island of Montreal, and this sense of separa teness has been both inscribed upon the area and been adopted from within:

To get there from just about anywhere, you have to cross either highways or find one of the sm all bridges across the canal. So it has always been a Here Be Monsters (or, at least, guys who could take $\mathrm{m} e$ in a fight) sort of place to $\mathrm{m}$ any Montrealers. ${ }^{75}$

The reduced mobility is reinf orced by ref erring to a sens e of distance in The Point, posited as physical but sym bolically understood as social. This is visible both in the narrative form and in the struc ture and activities of various initiatives. Residents use it positively, to explain difference. Largely, this sense of separation, expressed by residents

\footnotetext{
${ }^{73}$ J. C Walsh and S. High, "Rethinking the Concept of Community," Social History/Histoire Sociale 32, no. 64 (1999): 267.

${ }^{74}$ Kruzynski and Drolet, The Point Is-- Grassroots Organizing Works, 38.

${ }^{75}$ Paskal, "Tough but caring: That's the Point."
} 
and organizations, is linked to the idea of a stronger community: "What $\mathrm{m}$ akes "The Point" so special is the sense of community spirit, it's like living in a small town, yet it's within walking distance of downtown of the greatest city in Canada." 76

This use of community is strongly infl uenced by place; however, Massey points out that the linking of place and community:

is a misidentification. On the one hand communities can exist without being in the same place - from networks of friends with like interests, to major religious, ethnic or $p$ olitical communities. On the other hand, the instan ces of places housing single 'communities' in the sense of coherent social groups are probably -and, I would ar gue, have for long been -q uite rare. Moreover, even where they do exist th is in no way im plies a single sens e of place. For people occupy different positions within any community. ${ }^{77}$

Walsh and High further that when a person' $\mathrm{s}$ address is used as the determinant for inclusion within a community, there is a failure to recognize that pow er relationships can cause differences for members. ${ }^{78}$ Yet, it is a person's address in The Point that is used for inclusion within this broad static use of 'community' and questions of inclusion are rarely vocalized despite clear evidence of power struggles, linguistic tensions, and ethnic diversity. This conception of community is more representative of a co nnection to place then social connections and yet, as Lucy Taksa points out, despite the differences between place and community, "locality helps to define how people feel about a comm unity and their sense of belonging to it."79

According to Anthony Cohen, this use of community serves to present "the common interests of the members" ${ }^{\prime 80}$ to outsiders and requires a simplification of the term

\footnotetext{
${ }^{76}$ Kenneth Maki, "Point Saint Charles "The Point"," What makes "The Point" Special?, http://www.facebook.com/\#!/topic.php?uid=2258791996\&topic=2184.

${ }_{77}$ Massey, “A Global Sense of Place,” 27.

${ }^{78}$ Walsh and High, "Rethinking the Concept of Community," 257.

${ }^{79}$ Lucy Taksa, "Like a Bicycle, Forever Teetering between Individualism and Collectivism: Considering Community in Relation to Labour History," Labour History, no. 78 (May 1, 2000): 13.

${ }^{80}$ Cohen, The Symbolic Construction of Community, 35.
} 
to allow members to assimilate their own experiences within the larger context. It is the clear uncontested borders that seem real and significant, enabling residents of Point Saint Charles to assert their differences from others who reside in neighbouring working-class areas:

Some say "The Point" was a tough place (people always fighting) \& som e say that there was alot of" underprivileged persons living there" outsiders comments of course. What they did' nt know was that "The Point" was a very tight community that respected eachother $\&$ in their own way really loved eachother. $[\text { sic }]^{81}$

The Point's geographical distance allows for an imagined idea of an insular Point Saint Charles.

The sense of separateness and this use of community have led to comparisons that can be problematic, as illustrated by th e Centre Social Autogéré's bicycle-sharing program. When questioned by The Montreal Gazette about the potential for theft, Anna Kruzynski, one of the organizers:

expressed [...] confidence it will be $\mathrm{m}$ ade to fly. In Buckingham, near Ottawa, she said, the loss rate to theft was initially high - she didn't specify how high when such a free-bike project was launched there. But after six years, s he said, it was driven down to 20 per cent - with four recycled bikes of ev ery five making it through each summer. ${ }^{82}$

Buckingham is located thirty kilom etres outside of downtown Otta wa, in Quebec, with the 2006 Canadian census listing its population as 22078 ; it is considered part of the urban fringe of the Ottawa-Gatineau area. ${ }^{83}$ Surrounded by lar gely undeveloped land a comparison with The Point is difficult at best, but telling.

${ }^{81}$ Kenneth Maki, "Point Saint Charles "The Point".", accessed, May 31, 2010

${ }^{82}$ Jan Ravensbergen, "The Point pedals faster on shared bikes; Introduces community fleet. Next step for Centre social autogéré is to occupy an abandoned building," The Gazette, April 19, 2009.

83 "Population counts, for census metropolitan areas and census agglomerations by urban core, urban fringe, rural fringe and urban areas, 2006 census - 100\% data," http://www12.statcan.ca/english/census06/data/popdwell/Table.cfm?T=207\&CMA=505\&S=0\&O=A\&RPP $=25$. (accessed June 3, 2010) 
The day aft er the launch of this fr ee bike sharing program I saw the brightly painted orange bikes at two stations, one on Charon Street and the other at the Charlevoix Metro. By day three, I coul d no longer find them. Despite the signs, it seems that the bikes were never returned to The Point, or perhaps, they were quickly stripped and do remain but are no longer identifiable by th eir markings. The bike-sharing progra $\mathrm{m}$ required no deposit and no regist ration; it was operated on an honour system . The theft of the bike s makes clear that locality does not create community and The Point's boundaries are porous, even if the access points are few and far between. Even still, this notion of segregation, funda mental to the cr eation of place, is carried forward and embraced in this construction of community ; the idea o f reduced mobility be tween residents and surrounding areas imply a stronger connection to place.

The bicycle program is but one exam ple of how instituti onalized community organizations and services often end up reinfo rcing this use of community and ultimately the power structures existing within it. This can be subtle or overt, internal to Point Saint Charles or externally imposed by various levels of politics, though these tend to be mainly municipal. The local library, swimming pool, arena a nd parks that create social spaces for residen ts are often preceded by the word community in comm on use and various organizations within The Point in clude community in th eir names, mission statements, or descriptions of their activities. Yet few, if any, evoke community critically. The Point Saint Charles Community Theatre and the Community Clinic of Point Saint Charles are obvious exam ples. Others incl ude: the Centre Social Autogére which endeavours to reclaim abandoned buildings an d create community centres and therefore 
shared social spaces ${ }^{84}$; La Pointe Libertaire, who seek to "créer une dynam ique vers l'autogestion du quartier par se s citoyennes et ses citoyens" ${ }^{85}$ and requires m embers to "have a marked interest for Point St. Charle s - either live in the neighbourhood or be in love with it" "86; the Comité NTU, which is a "Comité citoyen pour la réduction des bruits et vibrations émanant de l'activité ferroviaire à Pointe-Saint-Charles" ${ }^{187}$; and the Comité de résistance au p rojet Nordelec (CRAN) which is "un com ité de citoyens et de citoyennes du quartier Pointe -Saint-Charles (Montréal) formé à l'automne 2007 a fin de lutter contre la réalisation du projet Nordelec". ${ }^{88}$ Linking many of these or ganizations together is Action-Gardien:

la table de concertation comm unautaire du quartier Pointe-S aint-Charles. Elle regroupe une vingtaine d' organismes. Depuis 1981, Action-Gardien est l'outil que se sont donnés les or ganismes communautaires et associatifs pour s'informer, partager leur expérience et agir ensem ble sur les dossiers qu i influencent les conditions de vie des citoyennes. ${ }^{89}$

Clearly, these organizations localize their activities to the level of place. In addition, they often serve to reinf orce beliefs about the constructions of community which residents hold dear.

Linkton and Russo posit that the "[i]m age of Youngstown as a place of loss is probably the $\mathrm{m}$ ost powerful and endurin $\mathrm{g}$ representation to emerge from deindustrialization." 90 On one hand, this also applies to the Point, $\mathrm{m} \quad$ any of the aforementioned organizations list demographic statistics, including levels of poverty and

\footnotetext{
84 “Centre social autogéré," http://www.centresocialautogere.org/en/node., accessed June, 3, 2010

85 “qui sommes nous? | La pointe libertaire," http://www.lapointelibertaire.org/quisommesnous., accessed June 3, 2010

86 "flyerPointelibertaire.pdf," http://www.lapointelibertaire.org/files/flyerPointelibertaire.pdf., accessed June 3, 2010

87 "Comité NTU," http://www.nousetlestrains.org/wp/., accessed, June $3^{\text {rd }}, 2010$

88 "Comité de résistance au Nordelec (CRAN)," http://www.nordelec.net/cran_en., accessed, June 3, 2010

89 "Une concertation active et solidaire | Action-Gardien," http://actiongardien.org/action-gardien, accessed June 3, 2010.

${ }^{90}$ Linkon, Steeltown U.S.A, 152.
} 
social assistance. ${ }^{91}$ The universality of their claim s is bolstered by their construction of place and despite changing dem ographics this stance remains largely unchallenged. However, this image of loss has been transformed to become a uniting experience for the community. These narratives of poverty, and the implied solidarity, reinforce notions of a generalized pain for the comm unity. By emphasizing poverty and struggle, the community organizations also em power, and have become arenas where resid ents can fight the accepted "reality" of an impoverish ed community. Cohen points out that "a more recent strategy observed am ong ethnic and other disadvantaged groups has been to 'honour' the stigma, to render it as a positiv e value, and th ereby, to destigmatize it". ${ }^{92}$ Beyond simply honouring the stigm a, the idea of being a disadvantaged community is frequently cited as the reason The Point is so special:

The ora $[$ sic $]$ of the Point is dif ferent from everywhere else. It's a place where you feel special. Everyone knows everyone, and everyone's parents all grew up in Griffintown together. Despite all the rumors and bad reputation, I never felt as safe anywhere else as I do when I'm ther e. No one realizes that they are poor , because everyone is on the same level. ${ }^{93}$

This assumption of universal poverty help s enable comm unity cohesion by assuming commonality and creating significant difference from surrounding areas. As Linkton and Russo point out "the idea of community can provide a powerful unifying force for shared struggle and community development" ${ }^{\prime 94}$ which is what has happened, and continues to happen, in The Point.

The residents that agitated $\mathrm{f}$ or better conditions, and the or ganizations that supported them, were in turn influen ced by global forces. The 1960s was a

\footnotetext{
${ }^{91}$ In the subsequent chapter these statistics and their use will be explored in depth.

${ }_{92}$ Cohen, The Symbolic Construction of Community, 60.

${ }^{93}$ Kim Davie, "Point Saint Charles "The Point".," accessed May 25, 2010

${ }^{94}$ Linkon, Steeltown U.S.A, 240.
} 
transformative period; it was a powerf ul time for activism in The Point and for North America in general. Sean Mills links the rise of activism in Montreal to the release of Franz Fanon's Wretched of the Earth, which arrived in the city in 1961. While the motivations behind the re-im aging of Montreal, as a classic co lonial city, are d eeply rooted in the Francophone/Anglophone power rela tions present at the tim e, "[i]deas of Quebec decolonization were appropriated and readapted by a wide variety of political movements representing the interests of previously disenfranchised groups...". 95 Although the ideology behind the explosion of radical thought in Montreal $\mathrm{m}$ ight have been different, activism was occurring globally . In North America, anti-Vietnam War protests and the American Civil Rights movement were rocking polit ical structures and industrial decline and the threat of urban ren ewal, which I w ill discuss in the follow ing chapter, were polarizing class relations.

Isabelle Drolet and Anna Kruzynski argue that pride in the neighbourhood, challenging living conditions and a wariness of the local elite left the Point fertile for activism which resulted in positive gains f or residents. ${ }^{96}$ Among other things, citizens formed a community health clinic, lobbied for changes to road speeds, petitioned the city for more parks, and managed to have the route of the local bus changed in order to better serve the neighbourhood. ${ }^{97}$ David Harvey ar gues that "the diminution of spatial barriers has provoked an increasing sense of nationalism and localism, and excessive geo-political rivalries and tensions, precisely because of th e reduction in the power of spatial barriers

\footnotetext{
${ }^{95}$ This has since been published as a book. Sean William Mills, The Empire Within: Montreal, the Sixties, and the Forging of a Radical Imagination (Queen's University, 2007), 4, http://hdl.handle.net/1974/900.

${ }^{96}$ Here the acknowledgment of a local elite contradicts the assumption of a single community suffering and gives insight into the cleavages within this broad static representation, creating evidence of dissent in the idealized notion of the past. This will be explored further in the following chapter. Kruzynski and Drolet, The Point Is-- Grassroots Organizing Works, 38.

${ }^{97}$ For a comprehensive look at all of these projects consult, Kruzynski and Drolet, The Point Is-Grassroots Organizing Works.
} 
to separate and defend against others." ${ }^{98}$ In essence, connection to place is a reactionary response intended to return a sense of stability to the identity-challenging compression of space-time. The women from the Courte Poin te Collective, for instance, frequ ently stressed that projects were started in The Point by people from The Point. They furthered that activists were suspicious of projects coming in from the outside, so even if the idea came from an external group, they started their own projects. 99 These assertions are contradicted, by discussions of profe ssionals that either helped or hindered the wom en's progress, ${ }^{100}$ and by the involvem ent of outside or ganizations such as McGill University, Université de Montreal, The Parallel Institute, and The United Church. While this could be seen as supporting Harvey's assertion, perhaps it has a different meaning.

Massey urges us to consider peop le's need for attachment, to place or otherwise, and asks "how to hold on to that notion of geographical difference, of uniqueness, even of rootedness if people want that, without it being reactionary."101 She furthers that plac es "can be im agined as articu lated moments in networks of social relations and understandings"102 The women of the Courte Pointe Collectiv e's engagement with activism began because their children's schools, their homes, and alm ost everything in their lives was located in The Point proper. ${ }^{103}$ Rita Walters' involvement was spurred in a similar way:

\footnotetext{
${ }^{98}$ David Harvey, "Between Space and Time: Reflections on the Geographical Imagination," Annals of the Association of American Geographers 80, no. 3 (1990): 427.

${ }^{99}$ Groupe anglophone, "Tissons une courtePointe: L'histoire de l'action communautaire a travers les histories de vie de femmes de Pointe St-Charles.."

${ }^{100}$ Groupe anglophone, “Tissons une courtePointe: L'histoire de l'action communautaire a travers les histories de vie de femmes de Pointe St-Charles.," interview by Isabelle Drolet and Anna Kruzynski, March 26, 2002, MG 4263, Acc. 2008-0024, McGill University Archives.

${ }^{101}$ Massey, “A Global Sense of Place,” 26.

102 Ibid., 28.

${ }^{103}$ Groupe anglophone, "Tissons une courtePointe: L'histoire de l'action communautaire a travers les histories de vie de femmes de Pointe St-Charles..”, May 7, 2002
} 
What started it all was that $\mathrm{m}$ y youngest daughter went into the pre-kinder garten program and there was $16 \mathrm{~m}$ others, we all met, one morning a week and discussed what was our problems or whatever and we became close close knit. 16 people that didn't know each other prior to that. It was jus $t$ fabulous. And I guess I showed some leadership or something because I just got to organize whatever was going on and it was quite interesting but sometimes I'd look back and say, "I don't remember I said that. Did I say th at?" Because I kept notes of everything I did and went and whatever and it was kind of interesting to see myself growing, but fearful because I didn't know where I was going and all thes e people were pushing me on... pushing me on... ${ }^{104}$

In both cases, the role social networks play ed in strengthening ideas of community, and the locality that housed them, is param ount, lending weight to Massey's argument and challenging the static interpretation of place that defines The Point as simply a product of its boundaries.

Yet these two ideas are clearly linked. Massey points out "that the geography of social relations is changing. In $\mathrm{m}$ any cases such relations are increasingly stretched out over space." ${ }^{\prime 105}$ Women from the Courte Po inte Collective believed that a change in the school system decreased people's connection to an insular Point Saint Charles. Children are now bused outside of the area, and $\mathrm{m}$ ake friends that live outside of The Point. As mobility within the larger context of Montreal increases, they argue that people are less likely to be involved in their communities. ${ }^{106}$ This reinforces Taksa's argument about the ways that locality helps to define a sens e of belonging, suggestin $g$ that the changing nature of place is threatenin $g$ the community. Even if the rate of participation has decreased The Point remains a site of resistance for many.

In 2006 activists prevented Montreal' s casino from relocating to The Point after a long battle with the City and recently, protests and demonstrations have centered on the

\footnotetext{
${ }^{104}$ Walters, interview., Montreal, Quebec

${ }^{105}$ Massey, "A Global Sense of Place," 27.

${ }^{106}$ Groupe anglophone, "Tissons une courtePointe: L'histoire de l'action communautaire a travers les histories de vie de femmes de Pointe St-Charles..", May 7, 2002
} 
future of the Canadian National Railway yard s. Groups are also agitating against an increase in noise caused by the privatization of the railroads. This issue has been a source of conflict. After several postings on Facebook regarding upcom ing actions the following was posted:

No offense but the trains have been $r$ unning through the Point longer than we' ve been around, I live close to the tracks, I knew this when I decided on this particular apartment. Are the people com plaining new residents to the area, part of the gentrification wave? ${ }^{107}$

This position was then rebutted by two m embers of the group, the firs $t$ asserted her right to fight Canadian National Railroad as she had been a resident for 28 years and saw an increase in the noise pollution ${ }^{108}$ and the second argued that it did not matter if you were born in the Point or if you were currently a re sident but that "as neighbors we should all stick together." ${ }^{\prime 109}$ This is not the first time that activism in this place has led to conflict.

The women of the Courte Point Collective admitted that they were selective with their choice of issues due to the potential reaction s of their neighbours. While the presence of drugs in the neighbourhood was a problem, the women argued that they knew the people involved; everyone was inter -connected. Identifying the potential tar gets of their action as "their people" th ey chose instead to focus on issues that stemm ed from outside the community. ${ }^{110}$ In David Fennario's popular play, "Balconville", Irene Regan is actively involved with the committees yet fails to get support fr om any of the other players. The meetings ("Yeah, everybody's sitting around with a long face....Boring!","11)

\footnotetext{
${ }^{107}$ Flow T.A., "Point Saint Charles "The Point".,", accessed June 6, 2010

${ }^{108}$ Caroline Di Cesare, Ibid.

${ }^{109}$ Denis Boudreau, Ibid.

${ }^{110}$ Groupe anglophone, "Tissons une courtePointe: L'histoire de l'action communautaire a travers les histories de vie de femmes de Pointe St-Charles..”, May 7, 2002

${ }^{111}$ Fennario, Balconville, 49.
} 
and the actions ("Y eah, sure. Another demonstration. Big fuckin' deal!"112) are quickly dismissed. The women of the Courte Pointe Collective did not always get the unanimous support they would have liked and thereby recounted $\mathrm{m}$ oments where they were actively mocked; this certainly $\mathrm{m}$ ade it dif ficult to be involved. ${ }^{113}$ Yet the m obilization and success of many of these groups is important to the identity of Point Saint Charles.

Positioned as community victories, the tr iumphs of various actions are recounted with a sense of ownership:

It was getting together and taking care of each other that stopped th e Vanier project from splitting the Point in two and destroying Margaret Bourgeoys park. It was our strong sense of community that got us the first citizen run Community Clinic in C anada! There was [ sic] always tim es that kicked our as ses and knocked us down BUT we always got back up got together and as a community kicked ass back and WON! This is what makes the Point so special to me! ${ }^{114}$

These tales of activism are, according to Michel de Certeau, empowering and serve to help create a common narrative. They:

frequently reverse the relationships of power and, like the stories of $m$ iracles, ensure the victory of the unfortunate in a fabulous, utopian space. This space protects the weapons of the weak against the reality of the established order. ${ }^{115}$

These stories allow for a perception of shared interests, in this case a defense of the common place, and a sh ared experience of vict ory. For a long tim e, residents of The Point have been fighting against pressures that threaten these carefully constructed notions of place, memory and community, which are all central to the construction of identity. Harvey reminds us that:

\footnotetext{
112 Ibid.

${ }^{113}$ Groupe anglophone, "Tissons une courtePointe: L'histoire de l'action communautaire a travers les histories de vie de femmes de Pointe St-Charles.," interview by Isabelle Drolet and Anna Kruzynski, February 12, 2002, MG 4263, Acc. 2008-0024, McGill University Archives.

${ }^{114}$ Paul Ayotte Skipper, "Point Saint Charles "The Point".", www.faceboook.com, What Makes the Point Special?", accessed April 23, 2010, http://www.facebook.com/\#!/topic.php?uid=2258791996\&topic=2184

${ }^{115}$ Certeau, The Practice of Everyday Life, 23.
} 
societies change and grow, they are tr ansformed from within and adapt to pressures and influences from without. Objective conceptions of space and time must change to accommodate new material practices of social reproduction. ${ }^{116}$

The Point's current conflict is tou gh to fight. The changes started slowly, have now accelerated and yet the threat is undefined. Tied up are ideas of class, changing aesthetics and an encroaching city reach.

Relics from the Centre S ocial Autogéré's bicycle-sharing program remain in The Point, taking their place am ong other physical reminders of times gone by. In its stead: Montreal's public bike system Bixi. The Centre's bikes were donated and decorated; a mishmash of styles. Bixis are identical silver with a polishe d finish. While the Centre's program limited itself to The Point, Bixi stands are island-wide, mobility is increased and users' sense of place might all together be larger. The ideology behind the Bixi system is also different; there is no im plied community trust $-\mathrm{u}$ sers must provide a credit card number to borrow a bike. The sense of sepa rateness that differentiated The Point from Montreal is challenged by Bixi; the city is getting closer.

${ }^{116}$ Harvey, "Between Space and Time," 419. 


\section{Chapter 2: Bringing Class Back to The Point}

Joe Beef stars in another piece of theatre, this one arguably better known than the scripts that bring him to the stage for the historical market. David Fennario uses him as the protagonist in Joe Beef: A History of Pointe Saint Charles. The play, produced by the local Black Rock Community Group, won the Prix Pauline Julien from the United Steelworkers' Union in 1986. ${ }^{117}$ Employing quite a bit of artistic license, Fennario's Joe Beef launches into a diatribe from the unde fined but fairly contem porary present about the abuses of the established authority of th e church and the wealt hy. Fennario purports to tell the history of the area begin ning with the establishment of the relig ious orders, introducing the Anglophone elite, and ending with a fairly fi ctionalized account of the strike during the third phase of the Lachine Canal. Fennario's play, like the $\mathrm{m}$ emory of Joe Beef himself, cannot be separated from ideas of class. In the play, Beef's patro ns are divided from the affluent with only Joe to defend the downtrodden. Joe Beef himself was known to bridge the gap between the classe $\mathrm{s}$; hero to the working class by providing food, bail money and a warm bed if needed, and influential enough to at least be tolerated by Montreal's wealthy: "He is respected a little in some decent quarters, and the vagrants look upon him as their best friend". 118 At his death, in 1889, La Minerve estimated his assets at $\$ 80000,{ }^{119}$ and his funeral was reportedly attended by m embers of all social classes. $^{120}$ In communal m emory, Beef's controversial behaviours are rarely m entioned;

\footnotetext{
117 "Fennario, David. Canadian Theatre Encyclopedia," http://www.canadiantheatre.com/dict.pl?term=Fennario\%2C\%20David. (accessed, October 26, 2010)

118 "The Canadian Voyageur - Continuing the descent of the St. Lawrence," The New York Times, August 20, 1881, http://query.nytimes.com/mem/archivefree/pdf?res=F20917F93C541B7A93C2AB1783D85F458884F9.

119 "McKiernan, Charles," Dictionary of Canadian Biography Online, http://www.biographi.ca/009004119.01-e.php?BioId=39816\&query=joe\%20AND\%20beef. (accessed, July 2, 2010)

${ }^{120}$ DeLottinville, “Joe Beef of Montreal,” 36.
} 
he is simply remembered as a working-class hero. ${ }^{121}$ In this, he has become a sym bol of resistance for residents who would like The Point to re tain its working-class roots as the demographics of the place chang e. W ith the recognition of Point Saint Charles' proximity to the downtown core of Montreal, Point residents are forced to acknowledge, even if not always overtly, th e role that class $\mathrm{p}$ lays in their memories, community and understanding of place.

While the industrial heyday of The Point is visible in the la ndscape and through public history exhibits, the pe riod of industrial decline is remembered by residents of Point Saint Charles. These $\mathrm{m}$ emories help shape their understand ings of place and community and contextualize the current transf ormation of The Point. This tim e period has the potential to be c onflicted and contentious so unlik e the pastoral period and the birth of industrialization, this era is rem embered in different ways. Larg ely narrative based, understanding of this tim e comes from personal and parental $\mathrm{m}$ emories. The transformation of the neighbourhood is hinde ring the physical rem inders of the tim e; abandoned factories are transform ed into c ondominiums, housing stock renovated, and sources of public history about this period are rare. By reconstructing this period through memory, residents are able to assert som e control over their changing landscape, even if that control is tenuous and historical.

Following a North American trend, factories started to close in the 1920s and the process accelerated drastically after World War II. Encumbered by old manufacturing stock and faced with em erging technologies that enabled increased productivity, many businesses chose to relocate to em erging industrial parks that offered appealing tax

\footnotetext{
${ }^{121}$ For information on some of the controversies that dogged Joe Beef, see DeLottinville, "Joe Beef of Montreal."
} 
breaks or to countries with lax environm ental laws and cheaper labour. In The Point, by the 1960s and 1970s m ajor employers were closing their doors and laying off their remaining workforce; Northern Electric, bui lt in 1913 with m ore modern infrastructure, relocated its production entirely by 1976 :

The departure of Northern Telecom from the Shearer street building now leaves the Connot plant on St Patrick Street wh ere 285 employees make metal products as the only remaining company manufacturing operation in the City of Montreal proper. The other fiv e plants in the Greater Montreal area are d ispersed throughout adjoining municipalities. ${ }^{122}$

It had once employed 9000 people.

Desmond Andrew Bleik conjures this image:

If the Lachine Canal is the key infrastruct ure of Canadian industrialization (it is of-ten referred to as the 'birthplace of Canadian industry') then by the 1950s, with the opening of the Saint-Lawrence Seaway, and at th e very latest by the 1970s, with the filling of its eastern end the $m$ otion of capitalism (towards suburban greenfields or overseas) had le $t$ it run aground on th $\mathrm{e}$ shoals of its fixity. ${ }^{123}$

Point Saint Charles had certainly run agr ound. The population dropped with the lack of work and services started to deteriorate. The unemployment rate was high and $40 \%$ of the population was on welfare. ${ }^{124}$ Those who were e mployed tolerated difficult conditions. While working environm ents might have been worse during the industrial period, memories of work during the industrial decline are al most tactile. Em ployment, therefore, became a struggle, either to surv ive without, or to accep $t$ what was available. This duality was aptly portray ed in Fennario's "Balconville". His character Claude Pauquette recounts that due to the energy cris is the bosses s topped air-conditioning the shop floor and one guy faints at his machine, yet the offices remain cool - another hint at

\footnotetext{
${ }^{122}$ Northern Telecom, "The Close of an Era. Shearer Edition.," Cablogramme/Cablegram, 4.

${ }^{123}$ Bliek, "Reweaving Urban Fabrics," 25.

${ }^{124}$ Kruzynski and Drolet, The Point Is-- Grassroots Organizing Works, 29.
} 
class tensions. ${ }^{125}$ Those without work reference how unjust the unemployment system is, and how futile they find the whole exercise. Tom Williams even comments: "I went down to the Northern Electric. I figured I've been breathing in their smoke all my life, so the least they could do is give $m$ e a job. Didn't get one... They're autom ating."126 In this, Williams alludes to another factor facing residents: pollution.

Once, pollution meant industry and livelihood. To Marcel Boudreau, a paper mill worker in Sturgeon Falls, smoke coming out of stacks meant he was making money, ${ }^{127}$ an allegory just as relevant in The Point. Pollution enveloped the area:

Oh yeah, very polluted and again, thi nk about the steam engines and everyone heating with wood and coal. The airbor ne pollutants were phenom enal, there was a lot of soot on everything and the noi se of the steam engines when they're running and shunting. No one in their ri ght mind would want to live near the tracks... out of the questi on! All you hear all day long is Chchchchche and Booooom because all of the industries were using rails. ${ }^{128}$

When most of the industries that had wr eaked havoc had moved on, the after-effects remained. Now residents had to contend with brownfields, contaminated bodies of water, and airborne pollutants generated by surrounding autoroutes, without the accom panying income.

Difficult employment and high levels of po llution were not the only challenges Point Saint Charles residents faced. Saddled with properties that were quickly aging, and dealing with absentee landlords meant that housing conditions continued to worsen. The women from the Courte Point Collective tell an engaging story about stealing a no longer needed toilet from a building when a landlo rd refused to replace th e one that had fallen

\footnotetext{
${ }^{125}$ Fennario, Balconville, 27.

126 Ibid., 21.

${ }^{127}$ High and Lewis, Corporate Wasteland, 32.

${ }^{128}$ Smyk, interview.
} 
through a bathroom floor. ${ }^{129}$ Denis Sm yk also had to contend with a difficult living situation:

Initially we were living in a cold flat, a cold flat means you've got no hot water. So at your kitchen sink you've got only a cold facet... and you've got no tub in the house so you can't bathe. All you have as your toilet is your toilet bowl in a little three foot by three $f$ oot closet, that's your toilet and you've got your kitchen sink, so if you want to take a ba th, well, you can't. You've got to heat up gallons and gallons of water or go to Hogan's bath. That's why you have public baths built in these shitty areas. ${ }^{130}$

Many people were living in sim ilar situations. By 1961, 52\% of housing needed repairs, $26 \%$ were lacking showers or bathing facilities and $42 \%$ were cold flats. ${ }^{131} \mathrm{~W}$ ithout proper facilities diseases spread and $\mathrm{m}$ any residents lacked accessible health care. Rats and cockroaches were a comm on problem. Maureen Ryan rem embers when Miste $r$ Beliveau, who they called the inner city hunter, tied rats to trees until the cats got them. ${ }^{132}$ Crime was ram pant, and fires broke out fr equently. Even though $\mathrm{T}$ he Point is not geographically large, there were two fire stations both with several trucks each. Arson was also a growing concern. ${ }^{133}$ As tenants, few people woul d have insurance and a fire almost certainly meant starting over from scratch. Once the fire departm ent would come “they'd make sure the fire is com pletely out, but your property was scrapped." 134 Like the industrial period before, these $\mathrm{m}$ emories help establish place and residents' role within it.

\footnotetext{
${ }^{129}$ Groupe anglophone, “Tissons une courtePointe: L'histoire de l'action communautaire a travers les histories de vie de femmes de Pointe St-Charles.."

${ }^{130}$ Smyk, interview.

${ }^{131}$ Kruzynski and Drolet, The Point Is-- Grassroots Organizing Works.

132 Ibid., 63.

133 Andre Picard, "Arson heats up trendy real-estate market," The Globe and Mail, June 4, 1996.

134 Smyk, interview.
} 
The area could have been perm eated with a feeling of hopelessness and desperation, and to many people it likely was. David Fennario certainly presented it that way:

The whole area stinks of broken dreams and insanity. Little taverns hugging the corners of the streets, f actory chimneys, matchbox houses, solitary lamplights and second hand-everyt hing is second hand. W e sell our love and hopes cheaply down here. ${ }^{135}$

Not surprisingly, poverty is a common topic within the evolving accounts. In this manifestation of "honoring stigm a", ${ }^{136}$ The Point is seen as special despite the poverty, "avoir une si "Belle" histoire... peu de coins de pays peuvent se targuer d'avoir un passé si "Riche", en dépit de la pauvreté qui y régnait", ${ }^{137}$ or because of it, “ no one realizes that they are poor, because everyone is on the same level". ${ }^{138}$ Numerous references are made about community services that helped people during these difficult times. For instance, Columba House, a community m inistry of the United Church of Canada, is often linked to childhood memories. Facebook contributors remember "COLUMBA HOUSE rushing there for lunch..."139 and that it "didn' $\mathrm{t}$ matter if you didn't have the best shoes....hell we'd all go to Colum ba house to get them free canvas runnin shoes to start school in September!![sic]"140 The underlying assumption is that everyone would have needed the additional support. The perception of The Poin $t$ as working class is fundam ental to the nature of the place, and the remembered cohesion of residents.

\footnotetext{
${ }^{135}$ David Fennario, Blue Mondays (Verdun, Quebec: Black Rock Creations, 1984), 39.

${ }^{136}$ Cohen, The Symbolic Construction of Community, 60.

${ }^{137}$ Benoit Lefebvre, "Point Saint Charles "The Point".,", accessed, June 13, 2010

${ }^{138}$ Kym Davies, Ibid.

139 Jon Mayar, "Point Saint Charles "The Point"”, accessed January 16, 2010; Bridge Morgan \& Judy

Robinson, "Saint Columba House,", accessed January 16, 2010, http://www.facebook.com/\#!/group.php?gid=20393131756.

${ }^{140}$ Susan Latmier, "Point Saint Charles "The Point".,", accessed June 13, 2010
} 
The memory of a homogenized class enviro nment exists in contrast to physical clues and societal ties that indicate othe rwise; The Point has long housed econom ically diverse individuals:

If you'll notice in the Point you got differe nt classes of hom es, of houses, the construction. Som e are better th an others, others are put up strictly as tenements, cold water flats for the lowest of the low. The landlord didn't give two shits about you as a tenant. ${ }^{141}$

The middle-class Victorian row houses that li ne Wellington Street are evidence of the semi-skilled and skilled workers, and managers, who lived there a t the turn of the 20th century and but one ex ample of class div ision etched into the lands cape. ${ }^{142}$ These divisions did not disappear wi th the industries. Local el ite remained, including Frank Hanely, a city councillor and independent Member of the National Assem bly, and the Magnans, owners of the restaurant and tave rn of the sa me name. "The Magnans had more money than we did. They never ate th e same thing twice. She cooked a piece of meat, and if there were any leftovers she sent them over to our house!". ${ }^{143}$ Rita Walters was once asked why, since she was em ployed by the school board and earning good money, she stayed in The Point. She responded:

Because if I live in the Point, there' $s$ classes here, and he didn't realize there were, and um I'm sort of on the top part of the class and if I move to another community I'd be on the bottom end of the class and that was part of it he never saw... ${ }^{144}$

\footnotetext{
${ }^{141}$ Smyk, interview.

142 "Griffintown and Point St. Charles Heritage Trail | Montreal Mosaic WebMagazine," http://montrealmosaic.com/attraction/griffintown-and-point-st-charles-heritage-trail (Accessed April 12, 2010); Smyk, interview.

${ }^{143}$ Kruzynski and Drolet, The Point Is-- Grassroots Organizing Works, 36.

${ }^{144}$ Walters, interview.
} 
Clearly, the stakes were not all even in Point Saint Charles, yet the harmonizing dialogue certainly presents it th at way. $M$ oreover, by becom ing universal, the experience of poverty is privileged and used to construct the place and who belongs within it.

Taljia Blokland argues that "[c] lass as a ca tegory is tied to socia 1 identification. Class is tied to space too, and people can us e the production of places for social iden tity formation." 145 The Point has been positioned as a place for workers or a place of poverty. This can be seen in the various publications of community organizations that continually use socio-economic status to describe The Po int. L'Action Gardien's website lists local statistics under the heading "Le quartier" contrasted to the rest of the Island of Montreal, solidifying a difference between the Point and the city. These figures include numbers on children of single parent families (50\% in The Point vs. $33 \%$ in Montreal), the population that is receiving welfare bene fits (15\% vs. $9 \%)$, those $r$ eceiving employment insurance benefits ( $35 \%$ vs. $13 \%$ ), those over 20 years of age that do not have a high school diploma (43\% vs. $27 \%$ ) and the average income (\$19 614 vs. \$28 858) am ong others. Notably, this data is attributed to Statistics Canada in 2001 and is taken before the pace of gentrification increased and large-scale construction of condominiums began which has changed the neighbourhood's demographics. ${ }^{146}$

Drawing on the "constitutive narrative", descriptions of the neighbourhood are contextualized within its history; often these claims are rooted in a history of the area that touches upon its foundations as a work ing-class neighbourhood borne with the development of industry in the area and the subsequent economic decline:

\footnotetext{
145 Blokland, "Bricks, Mortar, Memories," 269-270.

146 "Une concertation active et solidaire | Action-Gardien.", accessed May 23, 2010
} 
Berceau de l'industrialisation canadienne, Pointe-Saint-Charles a long temps été le lieu d'une intense activité écono mique avant de décliner graduellement avec la fermeture du Canal de Lachine et de ses nombreuses usines. ${ }^{147}$

The use of statistics, selectively deployed to invoke a working-class identity of place, is but one technique used, clas s-coded language is another common way of claim ing The Point. Use of the possessive "their" leaves no am biguity in this co ntext: "Conséquemment, la communauté est confront ée à un défi majeur: le m aintien des résidants dans leur quartier et l' amélioration de leurs conditions de vie.” ${ }^{148}$ Even extended beyond the possessiv e, the meaning is clear: "[The comm ittee is] aim ed at keeping housing for 'the people of the Point' in good condition and affordable"149.

A quiz in a docum ent entitled "Le Projet Sain t-Charles: L'histoire de citoyens et de citoyennes qui se s ont mobilisées pour demeurer dans LEUR quartier" asks why residents have had to protest to stay in their neighbourhood for so $\mathrm{m}$ any years. The response offers insight into why a narrative of resistance, rather than loss, is the enduring legacy of deindustrialization:

Parce que Pointe-Saint-charles est très bien situé (près du cana 1 , du centre-ville, du Vieux-Montréal, des pistes cyclables et des autoroutes) et que la ville de Montréal veut le mettre en valeur en y faisant des travaux majeurs de renovation urbaine, sans protéger la population act uelle des impacts négatifs de ce genre d'opération. ${ }^{150}$

With their place und er siege resid ents have fought back. The Point has the highest concentration of soci al housing in Canada. ${ }^{151}$ Residents, with the help of external organizations, started buying old properties, and renovating them in the for $\mathrm{m}$ of

\footnotetext{
${ }^{147}$ Ibid.

${ }^{148}$ Ibid.

149 "Pointe-Saint-Charles Action Watchdog committee presents "making things better and better"," MG 4263, Acc. 2008-0024, McGill University Archives.

150 "Le Projet Saint Charles: L'histoire de citoyens et de citoyennes qui se sont mobilisées pour demeurer dans LEUR quartier," April 25, 2001, MG 4263, Acc. 2008-0024, McGill University Archives.

${ }^{151}$ Among many others, see, Ibid.
} 
cooperative housing. These co-ops, added to the stock of other form s of soc ialized housing, has created a Point Saint C harles with 2210 dwellings dedicated to low-incom e households, representing over forty percent of the current housing stock. $\quad{ }^{152} \quad$ Two organizations have largely taken the reigns of this initiative: Le Projet Sa int-Charles and the Regroupement Information Logement (RIL). Both agitate for better conditions and create housing to help citizen $\mathrm{s}$ remain in their neighbourhood. ${ }^{153}$ Not only has this resulted in high concentrations of social housing, but it has also led to the repair of living spaces that had suffered years of neglect. Th e prevalent class positioning of The Point, and acknowledgment of concrete action by invol ved citizens, has even been developed into lessons for children. A bilingual module developed by the Popular Archives of Point St. Charles entitled "Le quartier où j' habite" focuses on social housing. Using a $\mathrm{m}$ ap, children in the target age of 9 to 12 , were to place $\mathrm{m}$ arkers on the various different social housing projects in their neighbourhood. At the end of the module they were to be able to identify the differen ces between "OSBL" (organismes sans but lucratif), "HLM" (habitations a loyer modique) and the cooperatives. ${ }^{154}$

Projet Saint-Charles and RIL along with other organizations have helped keep people in The Point who could not otherwise have afforded to stay. However, linking place to so cio-economic profile paired with this changin g built env ironment has in essence altered the m eaning of place for peopl e that use it. The socio-econom ic status

\footnotetext{
${ }^{152}$ Sources generally place the percentage of social housing between $46 \%$ and $48 \%$. Given new condo construction that percentage has likely changed and will continue to do so. For an example of the percentage of housing units see,"Pointe-Saint-Charles Action Watchdog committee presents "making things better and better"."

153 "Regroupement Information Logement et la Société d'amélioration de Pointe-St-Charles (R.I.L SOCAM)," http://www.rilsocam.org/ (accessed, October 3, 2010); "Le Projet Saint Charles: L'histoire de citoyens et de citoyennes qui se sont mobilisées pour demeurer dans LEUR quartier."

${ }^{154}$ Les Archives populaires de Pointe-Saint-Charles, "Guide d'activités: L'histoire populaire racontée aux enfants," April 2000, MG 4263, Acc. 2008-0024, McGill University Archives.
} 
has in this way ceased to be linked to the people that live there, but is now inscribed on the place itself: "Point Saint Charles is a low-income neighbourhood". ${ }^{155}$ The notion that The Point belongs to a certain popu lation implies a level of stability and helps confer the status of site of resistance. Buoyed by the sense of separateness, and reinforced by the area's activist history, residents stoically face threats.

A document held in the archives of the Point Saint Charles Community Clinic gives directions to its location. ${ }^{156}$ The full page illustration, created in 1995, contains a skewed Island of Montreal. Select Montreal neighbourhoods are Rom an forces, identifiable by their tents, uniform s, and the Roman standard planted in the foreground. They surround a village with straw thatched huts, encircled by wooden posts representing Gaul, but identified as Point St Charles. The image identifies Montreal as MontrealVM the $\mathrm{V}$ is intended as a $\mathrm{U}$ - alluding to Roman names which often ended in "um", but also serves a dual purpose as a stand in for Ville de Montreal. The invading Roman forces all have VM added to the end of their nam es, even though a few na mes have been abbreviated, so Westmount becomes WestmountVM and the W est Island is WestilVM. Pointe St-Charles, is notably not followe d by a VM. Based on the illus tration found in the French com ic book series Asterix and $\mathrm{Ob}$ elix the im age intends to express the assimilation of the rest of the island, while highlighting Point Saint Charles' resistance. ${ }^{157}$ The selection of cities positioned at The Point's doorstep is worth m entioning. They are not areas in close proximity to The Point, but rather the more affluent neighbourhoods in the city: Westm ount, Outremont, the W est Island and the Town of Mount Royal.

\footnotetext{
155 "Saint Columba House," http://www.saintcolumbahouse.org/. (accessed, November 11, 2010)

156 Sketch showing directions to Pointe St-Charles, Collage, coloured marks on paper, 1995, MG 4263, Acc. 2008-0024, McGill University Archives.

157 "Asterix Encyclopedia - Translations - Asterix in Latin - The official Website,"

http://www.asterix.com/encyclopedia/translations/asterix-in-latin.html. (accessed, September 3, 2010).
} 
Highlighting class issues, and physical differentiation from th e city of Montreal, this image is representative of strugg les The Po int has faced in the $p$ ast and foreshadows gentrification. Still, the clear message is that The Point is a site of resistance.

Strong physical boundaries and a class-based place identity make defense of The Point seemingly possible. These have help ed residents mobilize against a city-wide movement of urban renewal that began with Mayor Jean Drapeau in the 1960s. ${ }^{158}$ The Acting Council of Pointe St. Charles Ci tizens' Organizations and Block Action Committees warned ag ainst the plan in a new sletter entitled "The Pointe is an Urban Renewal Area or Beware the Bulldozer":

... In the past it has also $\mathrm{m}$ eant you may see a lot of dem olition and bulldozing with your torn-down houses not being repl aced by new ones. Victoriatown and the Radio-Canada building site were also urban renewal areas too! No poor or working people live there any more.[sic $]^{159}$

The sense of being under siege was real; areas all over the city of Montreal were being destroyed in the name of improvement. Drapeau, "a visionary, but not a planner", ${ }^{160}$ was known for his mega projects and international events. Montreal hosted Expo, the world's fair, in 1967 and the S ummer Olympics '76, and built, among others, the Complexe Desjardins, the Complexe Guy Favreau, the Pa lais des Congrès, Place des Arts, and the previously mentioned Radio-Canada building. He accomplished this through his "use of city powers of zoning and expropriation, wi th land swaps, and concessions to the developers". ${ }^{161}$ The experience of several near by communities solidified residents'

\footnotetext{
${ }^{158}$ For a detailed look at the city's urban renewal plan see,R. K Whelan, "The politics of urban redevelopment in Montreal Regime change from Drapeau to Doré," Quebec Studies 12 (1991): 155-169.

159 Acting Council of Pointe St. Charles Citizens' Organizations and Block Action committees, "The Pointe is an Urban Renewal Area, or Beware the Bulldozer," October 1972, MG 4263, Acc. 2008-0024, McGill University Archives.

${ }^{160}$ Whelan, "The politics of urban redevelopment in Montreal Regime change from Drapeau to Doré," 157. ${ }^{161}$ Ibid.
} 
commitment to resistance. One such comm unity particularly serves as a cautionary tale for The Point.

Let us r eturn for a moment to the Société d'histoire de Point Sain t Charles's booklet "A Brief History of the Streets and Pa rks in Point Saint Charles" where, on the back cover, the streets Conway, Forfar, and Britannia can be found. ${ }^{162}$ These streets n o longer exist, destroyed when the City of Montr eal as part of the preparations for Expo 67 razed the area they were a part of: Victor iatown known also as Goose Village. In addition to the nearby displacem ents that happened in Griffintown and areas of Little Burgundy, the City decided that Victoriatown and all of its 1800 peopl e had to go. In 1963 it expropriated and destroyed all of the homes; the light industrial area sits empty today with nothing to signify the displaced people who once lived there. The destruction of Goose Village offers a window into the changing nature of place and complicated class differences.

Goose Village was th eoretically within the borders of Point Sain t Charles; however, these individuals of English, French and Italian origins, and the place they inhabited, were not cons idered within the dom inant narrative until it was destroyed and the individuals were displaced. While $\mathrm{m}$ any chose to move within the established boundaries of The Point, there was still a perceived otherness about them and their community. As Denis Smyk tells it:

Even though the Point was low class that [Goose Villag e] was considered even lower! Those people got displaced and they all sought lodging here in The Point. So those kind of people I f elt lowered the ... cla ss level a bit, they knocked a little bit of the class out of The Point. ${ }^{163}$

\footnotetext{
${ }^{162}$ Société d'histoire de Pointe-Saint-Charles., A Brief History of the Streets and Parks in Point Saint Charles.

${ }^{163}$ Smyk, interview.
} 
With time the area where Goose Village stood became part of the place of Point S aint Charles. It is incorporated, although often kept separate, in the sources that are accessed by the general public, both form al, such as those produced by the So ciété d'histoire de Pointe Saint Charles and informal, such as thepoint.ca. One can see this treatment clearly in the SHPSC's booklet, as Victoriatown, and th e history of the stre ets it once contained, is found at the end within its own section. Preceding the history of the streets is a summary of the history of the area. In one short page it traces the use of the land and the history of the displacement. Even in this short narrative one can see the conflicted nature of place:

...Following Expo 67, the one-tim e citizens of Victoriatown asked the City to sell their land back to them so they c ould rebuild but their request was turned down. The citizens of Point Saint Charles had lost the only site from which they could see the majestic river. Now their view is the Bonaventure Autoroute and a vast parking lot that is nearly always empty. ${ }^{164}$

Infused with loss, the memory of Victoriatown has been appropria ted into the larger narrative of The Point, and yet kept separate; Goose Village's loss is not The Point's

In its use in the activist narrative, Victoriatown remains as a warning to residents of total destruction by the city, and as an example of why the class con struction of The Point is taking place. It is not alone. In the 1970s the City of Montreal started discussions about building a boul evard that would cut The Point in half. Requiring the demolition of houses on one sid e of Laprairie and both sides of Hibernia Streets, along with the destruction of the Fire Station built in 1891, the Boulevard was to connect a new bridge over the Lachine Canal with W ellington Street increasi ng traffic through the

\footnotetext{
${ }^{164}$ Société d'histoire de Pointe-Saint-Charles., A Brief History of the Streets and Parks in Point Saint Charles, 28.
} 
residential areas of The Point larg ely for commuters destined for the South Shore. ${ }^{165}$ Aside from the potential of expropriati on, the Boulevard proposal was rejected by numerous groups based on who they thought would profit $\mathrm{f}$ rom it. The Com ite Action Boulevard argued that "[i]l est bien évident á ce moment que ce sont les mieux nantis qui vont en profiter, pas le monde ordinaire de la Pointe qui ne pourra pas payer des loyers aussi élevés." 166 They saw the boulevard, and the a dditional passage over the Lachine Canal as making the area more attractive to people who worked downtown to move into The Point and perhaps more appealing to pe ople who would set-up businesses along the route taken, thus making them wealthier.

Aside from class issues a nd concerns about traffic $\mathrm{c}$ ongestion, residents worried about the additional division of their neighbo urhood. The Point is already div ided by railway tracks that run east to west and bis ect The Point preventing easy passage. This division has largely impacted the meaning of place because it has sym bolic importance; as seen in the Point Education Im provement Committee's educational module, it has tended to separate A nglophones who largel y lived in the sout hern portion and Francophones, who largely lived in the north. Conscious of the symbolic im pact of physical divisions, residents resisted, and won. The city never constructed the boulevard.

The fight extended beyond preventing dest ruction. The use of the land with new development projects $\mathrm{w}$ as, and remains, a divi sive issue. Initially, local organizations were fighting for the maintenance of industrial sites as places for job creation and tried to keep employment to those that lived within Point Saint Charles. Many of the founding statements of local organizations have a re sidency requirement in their $\mathrm{m}$ embership. A

\footnotetext{
${ }^{165}$ Comite Action-Boulvard, "Que Va Devenir la Pointe?," November 1, 1973, MG 4263, Acc. 2008-0024, McGill University Archives.

${ }^{166}$ Ibid., 2.
} 
document produced in the 1970s by the Conseil de Quartier de Pointe St. Charles states that:

[p]our qu'un delegue puisee sieger au c onseil de quartier, il faut qu'il soit resident de Pointe St. C harles. Cependant nous pourrons accepter jusqu'a cinq (5) delegues residents a l'exterieur du quartier. [sic $]^{167}$

This thread carries through much of the documentation available. In 1996, organizations argued that the Lachine Canal should rem ain industrial and that zoning changes that would allow housing should be prevented. ${ }^{168}$ These pressures are other ways that the remembered past of the industrial period - wh ere workers lived nearby and walked to the local factories - and the sense of separatene ss - manifested by a de sire for job creation linked to the area - are demonstrated.

Now the current battles over place and space in Point Saint Charles revolve around services (which s till to an extent wi 11 create jobs, although not of the industrial variety) and low-cost housing quotas within any new project. One can see this trend with the battle over the redevelopment of the vast landscape left behind by the Canadian National Railway and Alstorm in 2003. Ac tion-Gardien argues th at the $\mathrm{CN}$ yards represent a good opportunity for citizens of The Point:

Cette immense friche industrielle est le dernier grand espace à développer dans Pointe-Saint-Charles où il est possible de faire des gains pour le quartier, notamment en termes de logements et de services pour la population. ${ }^{169}$

With this project groups have begun to take ac tion against the very forms of industry that they used to battle for. They are figh ting against perm it changes that would allow industry that could bring pollu tion, vibrations, heavy loads, or noise into the area.

\footnotetext{
167 “Conseil de Quartier de Pointe St. Charles,” 1971, MG 4263, Acc. 2008-0024, McGill University Archives.

168 "No Title," 1996, MG 4263, Acc. 2008-0024, McGill University Archives.

169 "Un quartier à prolonger sur les terrains du CN | Action-Gardien," http://actiongardien.org/terrains-cndeveloppement.
} 
Recently, groups have largely focus ed the fight on maintaining the affordability of The Point, arguing for:

$40 \%$ de logem ents sociaux et $100 \%$ du site « abordable », pour tous les types de ménages. Le projet résidentiel do it respecter l'identité du quar tier et se réaliser dans le prolongement de ses rues. ${ }^{170}$

While it becomes clear that the identity of the neighbourhood to which they refer is one that retains its working-class roots, the ac $t$ of resisting ind ustrial projects in this $\mathrm{s}$ ame space negates this slightly and implies a shift in the socio-economic demographics of the area.

The desire to reign in the construction boom in The Point is a challeng e against gentrification and the new citizens that accompany it. This pressure on urban planners echoes a progressive regime in the typology of urban regimes posited by Clarence Stone and summarized by Robert K. Whelan, in which:

... middle and lower-class neighbourhoods gr oups play a m ajor role in policymaking. When dom inant, a progressive regime will expa nd services, pursue redistributive policies, and, perhaps, lim it growth a nd place controls on land developers. ${ }^{171}$

Regardless, these fairly new approach es to bettering the neighbourhood imply an increased mobility among its working citizens, jobs need not be located in the imm ediate vicinity any longer, and perhaps an awareness that the inconveniences of heavy industry outweigh the advantages of job proximity. Henri Lefebvre would link this shifting spatial practice to changing modes of production: "If each mode of production has its own space then the shift from one mode to another m ust entail the production of new spac e."172 There is no doubt that the ongoing dem ographic shift in the area is changing the meaning

\footnotetext{
170 "Un quartier à prolonger sur les terrains du CN | Action-Gardien,” http://actiongardien.org/terrains-cndeveloppement.

${ }^{171}$ Whelan, "The politics of urban redevelopment in Montreal Regime change from Drapeau to Doré," 155.

${ }^{172}$ Henri Lefebvre, Critique of Everyday Life (London: Verso, 1991), 46.
} 
of the place, even though it is far from

complete and perhaps even not yet fully

understood, it is in the process of creating this new space to account for the change in the mode of production from one of creation to largely one of consumption.

One only needs to loo $\mathrm{k}$ at the lo cal real estate listing $\mathrm{s}$ and the num erous condominium projects to realize that the area has become appealing to a section of the population that would not have lived there in the past. $\mathrm{W}$ ith this new econom ic period the landscape is changing. Mathieu Van Criekingen and Jean-M ichel Decroly have developed a typology of urban change, com plicating the often over simplified concept of gentrification. Two types of urban change ar e of particular im portance for The Point. Van Criekingen and Decroly's use of "gentrif ication" is of ten the inten ded meaning of the term which involves:

the metamorphosis of deprived inner-c ity neighbourhoods into new prestigious residential and consumption areas taken up by a new class of highly skilled and highly paid residents, typically business services professionals living in small-sized non-familial households ${ }^{173}$

They follow with "m arginal gentrification" to refer to a distinct and separa te type of urban change that involves people who "cannot be portrayed as a ' new urban elite' of yuppies because of their socio-econom ic (for example relatively m odest or unstable income) or socio-dem ographic (for exam ple, family with child ren) profiles." Th ese individuals are often "following Bourdieu's terminology, richer in cultural capital than in economic capital". ${ }^{174}$ While these two typologies can be linked, marginal gentrification is not necessarily the first step toward $\mathrm{s}$ gentrification. Shar on Zukin argues that "[g]entrification is an ef fort to a ppropriate downtown's centr ality - and also, by

\footnotetext{
${ }^{173}$ Van Criekingen and Decroly, "Revisiting the Diversity of Gentrification," 2452.

${ }^{174}$ Ibid.
} 
consuming it, to enhance it s economic and cultural valu $\mathrm{e}{ }^{175}$, this both increases the physical area of downtown and its cultural power. ${ }^{176}$ Visible in The Point, this argument is relevant for both types of gentrification.

Van Criekingen and Decroly' $\mathrm{s}$ approach moves away from the idea that gentrification is a singu lar process accomplished in stages, following a linea $\mathrm{r}$ path that once started, can largely not be stopped. The built environm ent in The Point is sp otted with houses that have been updated and renova ted among others that rem ain in various levels of distress. The continued trend in renovation is evidenced by the num erous contractor vehicles and the heaps of removed materials that line the street. Gentrification is, of course, about $\mathrm{m}$ ore than housing. The businesses, largely service-oriented, have also changed to $\mathrm{m}$ atch the consum ption patterns of the new residents. A quick walk down Centre Street reveals fa ir-trade coffee shops, restaura nts, a holistic spa and an artists' atelier. The businesses that cater to a new clientele remain inter-spaced with thrift shops and discount stores that also line the str eets. While this would seem at first glance to be evidence of the process of transfor mation that seems at the moment incomplete, I maintain that it is rather an indication that "several distinct processes are simultaneously occurring in cities and that th ese processes cannot a priori be reduced to steps with the progression of gentrification towards maturity.",177

Still, in many ways the gentrif ication pattern in The Point has $\mathrm{f}$ ollowed the one laid out by Zukin. ${ }^{178}$ While there is no doubt that th e urban renewal plan instigated by the City of Montreal attem pted to rebuild housing stock to appeal to a range of property

\footnotetext{
175 Zukin, Landscapes of Power, 186.

176 Ibid., 187.

${ }^{177}$ Van Criekingen and Decroly, "Revisiting the Diversity of Gentrification," 2452.

178 Zukin, Landscapes of Power, 188.
} 
owners that would broaden the tax base, Th e Point largely saw a shift away from the public to the private sector. ${ }^{179}$ Even before the funds ran out (the grant program offered by the City of Montreal for $\mathrm{m}$ ajor renovations to housing in th $\mathrm{e}$ area is no longer available ${ }^{180}$ ) there were deterrents to this program, largely that renovation expenses had to exceed a certain amount of investment (most recently $\$ 15000)$, a sum that not many in the area had read ily accessible. R ehabilitation using sweat equity and other form $\mathrm{s}$ of private investment replaced the large scale pu blic projects that requ ired either $\mathrm{m}$ ass destruction or massive investments. When I began search ing for a pr operty to buy it quickly became apparent that I had lim ited choices: I could purchase a finished property far from the city center, increas ing my commute and $\mathrm{m}$ aking access to downtown activities fairly difficult, I could buy a condo, or I could look for a house that needed to be renovated, in an area that was not yet as highly valued as others. W ithout additional capital, sweat equity became the only way I could conceivably buy a property and remain close to the city, a position that I am sure others have found them selves in. Due to my modest and fairly unstable incom e and my middle-class background, this firm ly places me within the wave of $\mathrm{m}$ arginal gentrification. Many of $\mathrm{m} y$ neighbours who have recently moved into The Point also do not fit the traditional gentrification demographic; the number of families with children is a clear indication of this.

A look at real estate listings that contain pictures indicates that the sellers of many of the houses "painstakingly restored architec tural detail covered over by layers of paint, obscured by repeated repairs and re-partitions, and genera lly lost in the course of

\footnotetext{
${ }^{179}$ For details about this aspect of the urban renewal plan, see, Whelan, "The politics of urban redevelopment in Montreal Regime change from Drapeau to Doré," 159.

180 "Ville de Montréal - Habiter Montréal - Rénovation résidentielle majeure," http://ville.montreal.qc.ca/portal/page?_pageid=4977,15819740\&_dad=portal\&_schema=PORTAL. (accessed May 23, 2010)
} 
countless renovations." ${ }^{\text {181 }}$ This also $\mathrm{m}$ atches my experience; $\mathrm{I}$ am in the process o $\mathrm{f}$ restoring my house to what I perceive to be its for mer glory, installing period specific pieces and exposing much of its form ally hidden architectural details. Many of $\mathrm{m} y$ neighbours, quite a few of whom are long tim e Point residents, are also restoring their properties this way. Many of these propertie $\mathrm{s}$ are either rental floors of duplexes, or cottages intended to be sold in the near fu ture, and, given the $\mathrm{m}$ arket, it is clear that properties restored in this $\mathrm{m}$ anner can comm and higher rental or resale prices. Zukin argues that this restoration is an a ttempt to "recapture the value of place". ${ }^{182}$ While her terminology remains problematic it does appear that the new residents of The Point, "by means of the building stock... identify with an earlier group of builders rather than with the existing lower-class population." 183 The contradiction here is that while gentrification may have, in some ways, been an attem pt to "recapture the value of place" the nature of the place $\mathrm{w}$ as undefined, and larg ely of an earlier perio d, so the incom ing residents themselves changed the meaning of place once more. This sense of place is reinforced by the City of Montreal with th e involvement of Heritage Mont real. Portions of the built environment of Point Saint Char les are iden tified as areas of histor ic interest, another indication that The Point is not entirely following a pattern of traditional gentrification. ${ }^{184}$ A "Heritage and quality renovation guide", des igned for hom e-owners and access ible online argues that:

A well-maintained house that has kept its or iginal architectural character is always a source of great pride for its owners. On the resale market, it will have

\footnotetext{
${ }^{181}$ See real estate agents's personal pages, or "REALTOR.ca - Welcome," http://www.realtor.ca/index.aspx?cul=1; .Zukin, Landscapes of Power, 192.

${ }^{182}$ Ibid.

${ }^{183}$ Ibid., 193-194.

${ }^{184}$ Van Criekingen and Decroly point out that this is normally the last step of gentrification that is intended to cement the area's new upper class status, Van Criekingen and Decroly, "Revisiting the Diversity of Gentrification."
} 
a value greater than that of a house that has lost its heritage elements and was altered to cater to passing trends. ${ }^{185}$

In many ways this seem s a direct enforcem ent of Zukin's position that the valuing of cultural consumption, and the so cial value of differing class es, positions historic buildings as belonging:

to people who have the resources to search for the original building plans and study their house in the context of the architect's career. They belong to residents who restore $m$ ahogany paneling and buy copies of nineteenth century facets instead of those who prefer aluminum siding. ${ }^{186}$

With documentation such as this guide, and a Programme d'aide à la restauration which provides limited grants $(30 \%$ of the to tal cost for renovations exceeding $\$ 5000)$ to maintain or rebuild e lements of architectural heritage, the city is in e ssence helping to create the place of Point Saint Charles as no longer for a working-class population as the neighbourhood organizations maintain, but rather for those $\mathrm{w}$ ho are able to restore the original, and often posited as the more authentic, built environment of the area. ${ }^{187}$

While it cannot be ascertained with conviction that all of this restoration in The Point is being done by the "new $\mathrm{m}$ iddle-class residents" that Zukin profiles, due to the current listing prices of the houses it is certa in that they are the intended prospective buyers, and most likely not of the marginal gentrification variety. ${ }^{188}$ These properties are added to the housing stock that is found in th e converted factories th at line the Lachine Canal, condominiums that, since their constr uction, were m arketed to the traditional demographic of gentrifiers. These properties are largely out of the financial reach of the

\footnotetext{
185 "Heritage and quality renovation guide," http://www.operationpatrimoine.com/guide/index_eng.htm. (accessed, October, 23, 2010)

${ }^{186}$ Zukin, Landscapes of Power, 193.

187 "Ville de Montréal - Patrimoine urbain - Programme d'aide à la restauration," http://ville.montreal.qc.ca/portal/page?_pageid=2240,18491562\&_dad=portal\&_schema=PORTAL.

${ }^{188}$ Zukin, Landscapes of Power, 192.
} 
marginal gentrifiers, myself included, (and far out of the reach of much of the workingclass population). However, the built environment has changed once more; the nu mber of multi-phase condo projects that are proposed or already built is increasing. These are largely being sold as affordable housing, and are marketed to young families, maintaining an element of marginal gentrification, indicating that in The Point at least, the process of gentrification cannot be simplified into a linear process.

Doreen Massey challenges us to as $\mathrm{k}$ "whether our re lative mobility and power over mobility and communication entren ches the spatial imprisonment of other groups" and while incoming residents might have chosen The Point for any number of reasons, most likely none of them , consciously decide $d$ that they would chose the area in an attempt to drive out the existing population. ${ }^{189}$ Regardless, this tends to have been the legacy, especially given that a large percentage of Point residents were renters before this change. ${ }^{190}$ This is just as true with the proce ss of marginal gentrification as it is with gentrification, even if the "term itself appears to minimize [it]" ${ }^{191}$ However, given the high percentage of social housing, there still remains a sizable population in the area that is fairly secure in their housing situation a nd who are not likely to be displaced without government involvement, which is, at least in the short term, unlikely to occur. Nonetheless, as the nature of place changes, even if it does so slowly, working-class residents might no longer recogn ize the place they once knew as The Point, a situ ation that in itself creates a sense of displacem ent The continual assertion of The Point as a

\footnotetext{
${ }^{189}$ Massey, "A Global Sense of Place," 26.

${ }^{190}$ Action-Gardien's cites $76 \%$ of the population as per the Canadian Census, 2001, "Le quartier en un coup d'oeil | Action-Gardien," http://actiongardien.org/Pointe-Saint-Charles.

${ }^{191}$ Van Criekingen and Decroly, "Revisiting the Diversity of Gentrification," 2456.
} 
working-class neighbourhood, is an indication of, and a reacti on to, the changes that are occurring.

At the corner of Centre and Charlevoix streets, right across from the Metro station the Regal Tavern, has becom e Le Chic Rega 1. Le Regal was once an establish ment where the video lottery terminals (VLTs) might have outnumbered the chairs and tables, and where everything was cast aglow by the large red neon sign that hung over the bar, complete with pickled eggs and a place to buy any Lotto Qu ebec tickets. Le Chic Regal is now a different establishm ent, complete with a wine list, curtained off VLT section, different lighting and a new paint job. The transfor mation is not complete; this face lift was not comprehensive enough to force old regulars to another tavern, but the prices have risen and the meaning behind the place is changing. In many ways the Regal reflects the experience of Point $\mathrm{S}$ aint Charles; changing and lost in $\mathrm{m}$ any ways, yet not unrecognizable. 


\section{Chapter 3: Putting the Unity back in Community}

When Joe Beef appears at the his torical market he is positioned and embraced as a working-class hero, a $\mathrm{m}$ antle that is, in part , justified. Af ter all, Peter DeLottinville suggests that he was fundam ental to devel oping a working-class culture in Montreal where "working class taverns $[\ldots]$ represente $\mathrm{d}$ one of the $\mathrm{m}$ ost basic for ms of public discussions." 192 However, these exchanges were not entirely inclusionary; wom en from the Courte Pointe Collectiv e expressed frustration that male activists had gotten their support in places that until the early 1980s were restricted to $\mathrm{m}$ en. ${ }^{193}$ While taverns had been popular in The Point, " $t$ here was a tavern on every corner. Every corner had a tavern!" ${ }^{\prime 194}$ the exclusion of women from this space was visible:

... when they'd get their $\mathrm{m}$ oney they $\mathrm{w}$ ould hit the taverns, and the sm art housewife would intercept the husb and at this point, because I've seen a lot of fighting where the wom en are outside, th ey're not allowed in the tav ern, and they're holding the door open with a broom screaming at their husband to get out there. ${ }^{195}$

The nature of taverns is thus contested; as is Joe Beef him self. While he offered men a way to forg et their troubles and engage with their p eers, women were given no such opportunities. ${ }^{196}$

This duality, and the complicated nature of this history, is absent from the Joe Beef Market. There, the feeling is conciliatory. Beef has been recast into a character that

\footnotetext{
${ }^{192}$ DeLottinville, “Joe Beef of Montreal," 11.

${ }^{193}$ Groupe anglophone, "Tissons une courtePointe: L'histoire de l'action communautaire a travers les histories de vie de femmes de Pointe St-Charles.," interview by Isabelle Drolet and Anna Kruzynski, March 13, 2002, MG 4263, Acc. 2008-0024, McGill University Archives.

${ }^{194}$ Walters, interview.

${ }^{195}$ Smyk, interview.

${ }^{196}$ There were other gender issues with regards to taverns. As Bettina Bradbury argues, even moderate spending on alcohol could ruin family budgets and Cyril Fisher recounts how taverns and alcohol led to conflicts. Bettina Bradbury, Working Families: Age, Gender, and Daily Survival in Industrializing Montreal (University of Toronto Press, Scholarly Publishing Division, 2007), 104; Patricia Burns, The Shamrock and the Shield: An Oral History of the Irish in Montreal, Dossier Québec series (Montréal: Véhicule Press, 1998).
} 
the entire community can embrace. The tavern is reformed, now a unifying memory, and its decline a loss: "every corner had a tavern! and um... they're all gone, which is kind of sad, in a way...”. 197 In this, Joe Beef provides an example of the re-m aking and reremembering of place and community in Po int Saint Charles. As when any collective identity is invoked, differences are being shunted aside and conflicting $\mathrm{m}$ emories smoothed out in the making of what Sherry Lee Linkon and John Russo would refer to as a "community of memory". 198

As Anthony Cohen reminds us the concept of community is always relational; what creates communities is not only their co mmonalities, but the belief that these commonalities cause co mmunities to differ significantly from other groups. ${ }^{199}$ Even though the boundaries between co mmunities are not always "objectively apparent" 200 those who are included in this community of memory understand what it m eans to be a "Pointer":

I have come across many different people who were very interesting ... but when you have been brought up in the point th ere is something different something that separates us from others [...] I'm very proud to be a pointer... it's really hard to explain this to othe rs they will never understa nd... only a true pointer knows and I feel sorry for those who will never have that bond. [sic]"201

Unlike, the use of community that equates residency with inclusion, the boundaries that envelope the "community of Pointers" are sym bolic; "Pointers" need not live in the area to be included in this definition. The boundaries are also malleable allowing for multiple conceptions of the same term and are very important to "Pointers"" sense of identity:

\footnotetext{
${ }^{197}$ Walters, interview.

${ }^{198}$ Linkon, Steeltown U.S.A, 3.

199 Cohen, The Symbolic Construction of Community, 12.

${ }^{200}$ Ibid., 13.

${ }^{201}$ Connie Rowan Kelly "Point Saint Charles "The Point".", accessed March 3, 2010
} 
As one goes down the 'scale' so the 'objective' referents of the boundary become less and less clear until they may be quite invisible to those outside. But also as you go down this scale, they beco me more and more important to their members for they relate to increasingly intimate areas of their lives or ref er to more substantial areas of their identities. ${ }^{202}$

Personal identities are not created in a vacuum; communal memory and place iden tity contribute to a sense of self.

Identity is a distinguishing factor between this use of community and the one that links residency with inclusion; "Pointers"” connection to the area goes beyond a physical address. This use of community exhibits " place attachment" - the social, psychological, and cultural bond that form s between individuals or groups and their environm ent."203 Peter Van Der Graff links place attachm ent to interpersonal relationships: "People become emotionally and culturally attached to the enviro nmental settings where they interact with other people."204 Place attachment as Setha M. Low suggests:

develops over time through personal involvement: living in a location, buying or decorating a hom e, telling stories about a particular landscape, and learning about the religious or cultural importance of a site... ${ }^{205}$

As these co nnections last long after "Pointer s" cease living in The Point, they can be reestablished through m emory. While the "c ommunity of Pointers" is being created, solidified, and accepted in the present, it is rooted in the past.

Though the boundaries that surround this use of community defy definition, a clear indicator is time. Having lived in The Point in the past, even if that past is undefined, is largely the only agreed upon requisite criteria for "Pointer" status. W hile social distance

\footnotetext{
${ }^{202}$ Cohen, The Symbolic Construction of Community, 13.

${ }^{203}$ Setha M Low, Behind the Gates Life, Security, and the Pursuit of Happiness in Fortress America (New York: Routledge, 2003), 85.

${ }^{204}$ Peter Van Der Graaf, Out of place? Emotional Ties to the Neighbourhood in Urban Renewal in the Netherlands and the United Kingdom (Amsterdam University Press, 2009), 37.

${ }^{205}$ Low, Behind the Gates Life, Security, and the Pursuit of Happiness in Fortress America, 85.
} 
might shrink through place attachment and community connection, the physical distance between members of this community and The Po int itself remains. Much in the s ame way that maps represent a moment in time, ${ }^{206}$ "Pointers" memories of place are frozen. If place attachm ent is "the sym bolic relationship formed by people g iving culturally shared emotional/affective meanings to a part icular space or piece of land that $\mathrm{p}$ rovides the basis for the individual's old group understanding of a nd relation to the environment" ${ }^{\text {207 }}$ then the relationship for med between "Pointers" is centered around a place that is lost. Whether they left by choice or through n ecessity, The Point the former residents remember no longer exists. Of the si x kinds of attachment that Low details one is therefore particularly relevant, that of a linkage due to land loss or community destruction. ${ }^{208}$ Since much of the physical landscape of the Point rem ains intact, although often repurposed, this loss is sym bolic. This manifestation of place attachment is retrospective and is achieved by rem iniscing and recreating place through m emory. ${ }^{209}$ This recreated place does not have boundaries that are as fi rm as the geographical ones; often interwoven and accepted as connected are the lost communities of Griffintown and Goose Village. When both were destroyed many of the residents moved to The Point and incorporated varying place and co mmunity identities into their new surroundings. Wanton destruction, ongoing gentrification an $\mathrm{d}$ repurposed landscapes are associated with a loss of community: "There was always a strong sense of community that seem s at

\footnotetext{
${ }^{206}$ Massey, "Places and Their Pasts," 188.

${ }^{207}$ Setha Low, "Symbolic Ties that Bind: Place Attachment in the Plaza," in Place Attachment, ed. Irwin Altman (Plenum Press, 1992), 185.

${ }^{208}$ Ibid., 166.

${ }^{209}$ Ibid., 167.
} 
times now to be dwindling." 210 While gentrification ofte $\mathrm{n}$ bears the blam e for this fragmentation of community many contributing "Pointers" left long before the influx.

The history of The Point has been marked by mobility, in the literal sens e, through the construction of waterways, autoroutes and railroads and in the figurative, by envisioning a sens e of separatenes s between The "inaccessible" Point and the re st of Montreal. Despite the sym bolic stability, these boundaries have been porous; people have regularly moved in and out of the area. Denis Smyk equates leaving with success: "you would be so happy back in the day to get out of Th e Point; you finally made it". 211

In this, The Point is similar to Lucy Taksa's class-constructed community:

A community formed on the basis of a common class position is not bound by time and place in th e same way [as other lived spaces]. Working-clas $\mathrm{s}$ communities in cities are $\mathrm{m}$ ore likely to be charac terized by $\mathrm{m}$ obility and impermanence... ${ }^{212}$

That said, The Point and par ticularly "Pointers" do not conform to her additional assertion:

... and thus tend to lack the so cial continuities that evolve over long periods of time in small towns or rural settings where shared identity and memory is often shaped in opposition to the outside world ${ }^{213}$

By positioning The Point as a bastion of wo rking-class values, the sole hold-out am ong Montreal's wealthy, and by the perception that strong physical boundaries present The Point more as a small village rather than an urban district, "Pointers" have maintained the "social continuities" that Taksa argues are norma lly lacking, and an atta chment to place, even if the connection is virtual.

\footnotetext{
${ }^{210}$ Paul Skipper Ayotte, "Point Saint Charles "The Point".", accessed, March 13, 2010

${ }^{211}$ Smyk, interview.

212 Taksa, "Like a Bicycle, Forever Teetering between Individualism and Collectivism," 23.

213 Ibid.
} 
A snapshot of thepoint.ca on any given day will rev eal the number of former residents that are invested in, and attached to, their comm unity and the neighbourhood. The field marked "where are you from" contains postings from various Montreal suburbs, including some of the $\mathrm{m}$ ore affluent, severa 1 US states, and cities all over Canada. Facebook groups also contain sim ilar information, even if it is not as explicitly stated. These online forum s reunite individuals wi th like-minded former residents and are comparable to the neutral McDonald's found in Tajlia Blokland's Hillesluis, where:

[w] hen sharing stories about the past on occasions such as at McDonalds, people who otherwise did not know each other, who had never met each other's family, been to each other's houses or in teracted in o ther parts of each other's life, assumed an equal position... ${ }^{214}$

The social networks provide new spaces wh ere "Pointers" are no $t$ shackled by what might have once created difference. The websites are enabling the form ation of new relationships without the risk of former categories and classi fications. Frequently, posts enquire about particular people, grieve lo st loved ones, share comm unity notices and reminisce about various Point schools and $\mathrm{r}$ ecount behaviours, events and experiences. Responses to these posts vary, but regularly, people share similar memories in response, even if the context, time-f rame or link between individua ls is tenuous. Tanya Edw ards posts:

I used to live on Augustin Ca ntin (Manufactures) and went to the new St Gab' s the first year it opened we were the first grade 6 class, Leona Legresly, Wayne, many others but I dont remember the names, from there we went to James Lyng. Loved going to hogans and the theater. Connie's made great pizza and the people were... great in the point. Later lived in Verdun and LaSalle but it wasnt the same. $[\text { sic }]^{215}$

Marlene Davis Minty responds with her similar life experience:

\footnotetext{
${ }^{214}$ Blokland, "Bricks, Mortar, Memories," 278.

${ }^{215}$ Tanya Edwards, "Point Saint Charles "The Point".", accessed, January 26, 2011
} 
I lived on Augustin Cantin for several years as well. From about 1977-1983 (in my late teens/ early twenties). The house number was 2722 -- almost right at the end across from the old factory (can't remember the name of the cross street). Yes, Connie's pizza was yummy. I went to Verdun High S chool. Didn't attend elementary school in Montreal. ${ }^{216}$

Carol Clifton adds that "[she] too went to st gab's first grade 6 class mr pearson". ${ }^{217}$

Allowing for equivalent, but not necessarily shared, experiences, these sites are creating a new community of people:

The countless number of Pointers, Griffint owners and Goose Villagers, I have met because of the site, has been my reward [for running the website] in so many ways. I know my life has been enriched in by getting to know so $m$ any of you folks that visited the site. ${ }^{218}$

Individuals who did not know each other while living in The Point have created relationships and now identify with in the re created memory of place within their own definitions of time. These new connection s are reinforced by frequent visits to the sites. Many individuals check thepoint.ca daily wh ich is encouraged by the site's changing pictures, layout, and backgr ound song, which often generate discussions on the guest book. ${ }^{219}$ In this manner "Pointers" have:

used local [or in this ca se virtual] facilities as meeting points to produce new local networks and to search for $\mathrm{s}$ ocial identifications with people th at they presumably would have ignored 50 years ago. They hence im agined a community by developing a sense of tim ebound 'localness' rather than 'social status' or even 'class' as a shared category. ${ }^{220}$

Even if these sites, and particularly thepoint.ca, encourage new connections, there is a glaring divide.

\footnotetext{
${ }^{216}$ Marlene Davis Minty, Ibid.

${ }^{217}$ Carol Clifton, Ibid.

218 George McRae, "Thepoint Guest Book."

${ }^{219}$ Bonnie Goven-Hunter illustrates this in her entry in the guest book on as she asserts: "First thing this morning I checked out the Point web site as usual...'Ibid., May 17, 2009

${ }^{220}$ Blokland, "Bricks, Mortar, Memories," 279.
} 
Language tensions in Point Saint Charle $\mathrm{s}$ have been presen $\mathrm{t}$ for a long tim e: "Back in 1955, but down in Verdun-Pointe Sain t Charles the blokes and the frogs were punching the shit out of each other on a regular basis that would sometimes block off the traffic in the streets. ${ }^{221}$ Linguistic differences were not always overcome by si milar class positions and The Point did not escape the political turmoil that has rocked Quebec. Although his Mother spoke fluent French and $60 \%$ of the custom ers at his store were French, Denis Smyk claims the two groups did not socialize. He asserts that this was not a result of any problems however:

Me and my brothers we would fight amongst each other, and my Dad would say OKAY, you know, brothers are not supposed to fight, if you guys want to fight go out there and fight with the French guys, they're all over the place, you know; that's the way it was. ${ }^{222}$

Most of the narratives have a sim ilar pattern, the narrative begins with an assertion that the two groups got along, followed by exam ples where they did not. The wom en of the Courte Point Collective start by as serting that there were no conflicts, everything was exaggerated and then slowly fights are rem embered at schools, at the YMCA, at a local hockey game... Most frequently, the center of thes e conflicts is at the railway tracks that divide The Point.

If, the tracks that crossed The Point became the physical division of the linguistic divide then the Facebook groups are the sym bolic. ${ }^{223}$ Some are predominately French and some English, but both sets of membership, are engaging in the process of refuting

\footnotetext{
${ }^{221}$ David Fennario, "From Rags to Richler An anglophone Montreal playwright wonders if he and Mordecai Richler grew up in the same province," Toronto Star, April 14, 1992.

${ }^{222}$ Smyk, interview.

${ }^{223}$ Kruzynski and Drolet, The Point Is-- Grassroots Organizing Works, 38, 55; "Point Saint Charles "The Point".." "mon dieu on dirait qu'il n'y a que des anglais.lol souvenez-vous l'autre bord de la track...le centre st-charles..baptême qu'on n'a eu du fun..”
} 
historical tensions and recreat ing a cohesive version of The Point. Past conf licts are dismissed as unimportant, "niaiseux"224 or quickly smoothed over:

I love Pointe St-Charles because it's the only place where y ou can kick some Irish ass (Griffintown powa), then ge $t$ your Frenchy ass whooped, then learn English (maybe some Gaelic if you're lucky enough), then stay friends, then feel at home. $[\text { sic }]^{225}$

Instead, The Point is positioned as a singular bilingual community: "anyone who grew up in Point St. Charles was bilingual before Bill 101 because we all spoke a certain amount of French. We may have murdered the language but we were never afraid of it” ${ }^{, 26}$ or as having a communal language that transcends these categories. A discussion board topic within a Facebook group is entitled "W e Have Our Own Language" and contributors have claimed words and expressions such as "fin" for a five dollar bill, or "pull the chain" instead of flush the toilet. ${ }^{227}$ Connie Rowan Kelley suggests that:

when you have been brought up in the point there is som ething different something that seperates us from others ... the strong bond that we all share ...the different way we $\mathrm{m}$ ay pronounce a word lo 1 lol that only $\operatorname{tr}$ ue pointers will understand we have are own language $101[s i c]^{228}$

In addition, they have reduced names of places in the area into other forms: Margaret Bourgeoys Park has becom e Maggy Bougy Pa rk, and Bourgeoys Street is pronounced Burgess. This language serves an exclus ionary purpose, helping to quickly identify newcomers, and helps reduce the distance between members of this recreated community keeping outsiders out.

\footnotetext{
224 “Ahhhhh nostalgie.... J'me rapelle de mon enfance marquée par les guerres niaiseuses entre anglais et francais", Julien Gagnon Mauffette, "POINTE ST-CHARLES.”, accessed January 5, 2010

${ }^{225}$ Luc Lefebvre, "Point Saint Charles "The Point"," accessed, October 23, 2009.

${ }^{226}$ Burns, The Shamrock and the Shield, 112.

227 "We Have Our Own Language, Point Saint Charles "The Point"," www.facebook.com, http://www.facebook.com/\#!/topic.php?uid=2258791996\&topic=2650.

${ }^{228}$ Connie Rowan Kelley, "Point Saint Charles "The Point".", accessed March 5, 2010
} 
Despite these assertions, a bicultural community is elusive. There is no Francophone equivalent to the thepoint.ca, nor seem ingly a com parable, widely-used, term for "Pointer", the occasional self-reference as Pointe St-Charlois notwithstanding. ${ }^{229}$ French Point resid ents, current and for mer, express sim ilar sentiments as English "Pointers", from assertions of being born in The Point, having grown-up there, or that: "ont dit,toujours que tu peut sorti homm ee de la pointe mais tu pourrais jamais;sorti la pointe de hommee $[$ sic $] "{ }^{230}$ Nevertheless, the use of a shar ed name is important, as Pierre Bourdieu argues, "everything that is a collective noun presupposes the existence of the group in question and conceals difference." $\quad 231$ W hile, these "co mmunities of memory" are engaged in reinventing The Po int as homogeneous, the general segregation of the linguistic groups, both geographically and socially, through school, church and community organizations, let a lone the tens ions that ex isted between them, results in reconstructions that are still lingu istically divided. So while similar processes are occurring among both groups, and the schism between them is not always clear, going forward, this work largely focuses on the Anglophone element.

If language, place attachment, and social networks can provide glimpses into some of the particular m eanings behind "Pointer", its boundaries are still intangible. Even on an individual level people have problems determining if they belong:

I am not a born Pointer but you would not know. I went there to live at the age of 17. First people were a little skep tic[al] of me but it took time and they were welcoming and because of their welcom e I became a Pointer and $p$ roud to be. They're right, you do have to understand their ways and that's okay but they are

\footnotetext{
${ }^{229}$ Maxime,"POINTE ST-CHARLES," accessed, May 12, 2010.

${ }^{230}$ Bruno Arcouette, Ibid. accessed, January 12, 2011.

${ }^{231}$ Pierre Bourdieu, "The social space and the genesis of groups," Theory and Society 14, no. $6(11,1985)$ :

741, http://www.springerlink.com/content/g71vq126122114t0/.
} 
very kind people and always ready to he $1 \mathrm{p}$. Some of my very good friends are Pointers. $^{232}$

Belinda Lee Ponter starts her post asserting th at she is a "P ointer", and then switch es to positioning herself as the "oth er". Residing in the $\mathrm{n}$ eighbourhood for a considerable period of time and espousing "Pointer" values can sometimes lead to acceptance:

I wish my daughter was here cause she' s a Pointer, you know, born and raised. She's a Pointer. A Pointer is som ebody who... knows your neighbours... who helps your neighbours, who's not... out ther e to get you. Who's genuine. W ho's friendly, and who cares about the community is a Pointer. That's how I see a Pointer as an adult. You know. My da ughter will see it, well she was born in the Point, she knows everybody. You know, so it all depends on who you ask, what the definition of a Pointer is... because I think anybody who lives in the Point, and who's lived here for $\mathrm{m}$ ore than 5 years at least, and got to know the neighbourhood and got to know the people wi thout judgment, that's a Pointer, somebody who does not judge... ${ }^{233}$

Being born in The Point, regardless of long- term residency, is understood as automatic inclusion in this community; being "Pointer" by birth does not depend "on who you ask". Otherwise, acceptance is carefully negotiated by time spent, memories shared and values adopted. David Harvey posits that "a partic ular way of represen ting space and tim e guides spatial and tem poral practices which in turn secure s ocial order." ${ }^{234}$ The lines drawn around these abstrac tions are unperceivable and allow for ambiguity. The undefined, and often individual, sense of tim e allows for "Pointers" to incorporate their experiences into the broade $r$ narrative of comm unity. The social order of this construction thrives o $\mathrm{n}$ a $\mathrm{m}$ alleable view of time and "the past" to allow for accommodation of various definitions within the community.

\footnotetext{
${ }^{232}$ Belinda Lee Ponter, "What makes "The Point" Special?," http://www.facebook.com/\#!/topic.php?uid=2258791996\&topic=2184, accessed, December 16, 2010.

${ }^{233}$ Anonymous, interview by Jessica J. Mills, March 23, 2010. Montreal, Quebec

${ }^{234}$ Harvey, "Between Space and Time," 419.
} 
While an elastic view of ti me can allow for inclusion there is one accepted lim it; new residents who came with gentrification are excluded from "Pointer" status. When Linda Wright defined "Pointers" in our interview it was with an awareness of my position in the neighbourhood. Her stated tim e frame of "five years at least" both let $\mathrm{m}$ e know that I was not included, having lived in The Point for three years, and taught me the values of the neighbourhood, im plying that the potential for inclusion was there if I "knew my place". Importantly, Taksa points out that exclusion and the dynamic of social differentiation that determines who is and who is not a member is integral to the concept of community, ${ }^{235}$ and social class provides that differentiation upon which the community is built:

Malheureusement, avec les années, les gens émigrent, déménagent et une population mieux nantie, plus im personnelle et plus superficielle s' y installe. Une population qui n'a pas l'orgueuil et la fierté que les natifs de l'endroit et ceux qui y résident depuis toujours ont. ${ }^{236}$

The Point has been positioned, and lauded, as a working-class neighbourhood, or a place of poverty, and new residents challenge the created homogeneity. Housing prices for this working-class neighbourhood are seen as over-inflated and gentrification perceived in the traditional sense, with wealthy individuals a ppropriating cultural capital. In the context of community, the people who have come with gentrification are dismissed as not sharing the same values as "Pointers". The area' $\mathrm{s}$ perceived status as trendy is ruining community cohesion:

une population pour qui ne pas connaitre $s$ on voisin et les jeunes du quartier est primordial, pour qui le co mmunautaire ressemble à une maladie...mais pour qui le mot "Quartier bien en vue" et le fait d'être "hot" est important ${ }^{237}$

\footnotetext{
${ }^{235}$ Taksa, "Like a Bicycle, Forever Teetering between Individualism and Collectivism," 17.

${ }^{236}$ Benoit Lefebvre, "Point Saint Charles "The Point"," accessed, October 17, 2009.

${ }^{237}$ Ibid.
} 
New residents are not as proud, are superficial, are judgmental and do not try and get to know their neighbours. In fact, they are polar opposites of Linda's "Pointers". The sense of loss and community change is palpable:

"i recently whent back to th e point,i feel so alon e,all i knew are gone,remember,i'm one of the boy's of the old butchery pierre,good old days are also gone.glad to see you on face book.' $[\text { sic }]^{238}$

Yet, the reasons behind this community of memory's revolt against gentrification are unique. While neighbourhood revitalization cause s great strain for $\mathrm{m}$ arginalized people living in these areas, these pressures do not largely apply to this community: $m$ ost no longer live in Point Saint Charles and thos e who do tend to be secure in their living situations. Interestingly, $\mathrm{m}$ any of the contributors to th is construction currently live in neighbourhoods with higher propert y values than the "gentrifie d" Point. Rather than displacement, at risk for "Pointers" is the memory of place and community.

For "Pointers", the threat lies in the shifting of value from people to place. Nicely summed up by anthropologists Robert C. Ch idester and David A. Gadsby is John Hartigan's look at gentrification. ${ }^{239}$ At issue is who controls history and where it is housed. In The Point, like in Detroit, there is:

a propensity of working-class whites to regard history in terms of people and events in the past, while middle-class whites tend to regard it was being related to material culture, particularly houses. For the middle class, houses are imbued with elevated monetary value because of their p ossession of (any) history - the history of working-class struggle, or alternatel y of neighbourhood unity, for instance - is transformed into a generic kind of history that is assumed to exist in old houses. ${ }^{240}$

\footnotetext{
${ }^{238}$ Stéphane Lapoint, "POINTE ST-CHARLES," accessed, January 27, 2011.

${ }^{239}$ J. Hartigan Jr, "Remembering White Detroit: whiteness in the mix of history and memory," City \& Society 12, no. 2 (2000): 11-34.

${ }^{240}$ R. C Chidester and D. A Gadsby, "One Neighborhood, Two Communities: The Public Archaeology of Class in a Gentrifying Urban Neighborhood," International Labor and Working-Class History 76, no. 01 (2009): 133-134.
} 
The trend towards rehabilitating old houses in The Point indicates that a similar process is occurring and I have frequently found myself exclaiming that my house was built in 1885 with the implicit suggestion that through virtue of age, histor $\mathrm{y}$ is attached. On the other hand, "Pointers" highlight $\mathrm{m}$ emories and recount history as it relates to the personal, or how people themselves have made the place unique.

These stories transform place in to the vessel for o therwise people-centric memories; here authority is derived from e xperience. Frederick Lear recounts a story about a weekly event he called the Grand Trunk Races:

On paydays, at the sound of the closing shop whistle, the men would literally run up Sebastopol, along Favard St. and past our house to the bank. The younger men and those in good physical condition would outrun the older men, and often there would be som e pushing and shoving as they tried to br eak into the line entering the bank. It was quite a sight and we looked forward to it. ${ }^{241}$

In Lear's version, the history that surrounds these buildings is in the m emories of the people that interacted with them. In othe $\mathrm{r}$ versions history resides in the place. Physically, the Grand Trunk workshops still exist in The Point and community groups are rallying to create a so cial space in Bâtim ent 7 because: "Il est vacant depu is 2003. Anciennement nommé le "bâtiment des magasins", il est témoin de l' histoire industrielle de Montréal. ${ }^{242}$ Unlike L ear's version, here it is the building that be ars witness to industry. Stories about the Lachine Canal $r$ ecounted by former residents follow a similar pattern of making place personal:

Now, I've swam in the canal when I was a kid. It's unbelievable the perils that are there... people's disregard for the waterway. When I was a k id ships were going through there 24/7. So you're on a sh ip and there's a broken $p$ iece of cable, might be 75 feet long, but its no good so you just throw it overboard. But that cable, it's very thick and it doesn't lie down like a wet skipping rope it stays

\footnotetext{
${ }^{241}$ Fredrick T.G. Lear, "In my day, the Point was a very different place," The Gazette, December 12, 1992.

242 "7 À NOUS : Le bâtiment 7 pour la communauté | Action-Gardien," http://actiongardien.org/terrains-cnbatiment7, accessed, January 27, 2011.
} 
up in the water. So I rem ember diving in off, they had rafts, diving in and coming up and getting scraped on the back by one of these cables and it' $\mathrm{s}$ a terrible feeling, it really hurt and I was $r$ eally afraid of infe ction. My old $m$ an told me "DON'T EVER DO THAT AGAIN" he's telling me stories about guys with ear infections, penis infections, throat infections, so I had to get treated with tetanus shots. ${ }^{243}$

Sometimes the place, while personal, is also symbolic and created through experience:

The Canal was freedom, that's what the Canal was. It was Huckleberry Finn and Tom Sawyer. There were no adults around. You knew there was a lot of danger and you tested it constantly. We used to dive down as far as we could go and get a handful of silt to prove we had done it. ${ }^{244}$

Fighting over the $\mathrm{m}$ eaning of history with new residents, "Point ers" solidify their similarities against outsiders. A flexible version of tim e, a seem ingly common class position, and experiential aut hority are some of the ways that "Pointers" create connections among them. Behaviours are another.

"Pointers" often express ways in which they did things dif ferently from other nearby communities, or habits that they identify with. In doing so the y are engaging in what Pierre Bourdieu would call hab itus. Habitus "produces practices and representations which are av ailable for class ification, which are ob jectively differentiated; but only by people who poss ess the code and schem es needed to understand the social meaning" and that ulti mately implies both a "sense of one's own place" and a "sense of the place o f others". ${ }^{245}$ Childhood experiences are frequently referenced this way. Mem bership in, or s upport of, Leo's boys, a sports oriented youth program (which was a boy' s and girl's club), is frequently thrown into conversations, without any explanation, allow ing for the assumption that pe ople know what that means in the context of The Point. Mo reover, hot lunches provided for 50 cents at St Colum ba

\footnotetext{
${ }^{243}$ Smyk, interview.

${ }^{244}$ Burns, The Shamrock and the Shield, 193.

${ }^{245}$ Bourdieu, "The social space and the genesis of groups," 19.
} 
house, 'Point Saint Charles' national anthem ', the Harlem Shuffle, which was sung and danced by locals, and other $\mathrm{m}$ ore common childhood activities from sports, to simply playing on the street, are re gularly repeated as ways The Point is unique. These memories, of common c hildhood activities are expressed with the sam e nostalgic voice and the sense of loss that saturates other recollections:

the point was the best.... tho times have changed and so did the faces...noone can take away the great $\mathrm{m}$ emories or fr iendships that we all $\mathrm{m}$ ade...COLUMBA HOUSE rushing there for lunch...leos boys an d of course the trips to hamilton... the point was the greatest place to grow up $[s i c]^{246}$

Teen and adult behaviours and experiences are similarly added to these nar ratives. Generally included are standing, and som etimes drinking, on variou s street corners, frequenting any of the numerous taverns or pubs or simply sitting on the balcony chatting with the neighbours. Like specific $m$ emories, typified by the Lachine Canal stories for example, these behaviours are often conveyed with a sense of adventure or associated risk. However, "Pointers" have accom panying experience of how to avoid the possible consequences or more frequently the close social ties that would negate that risk:

What can I say, it was the roughest neighbourhood around, but if you were from there you were safe. I loved the fact th at I could take the bus at $3 \mathrm{am}$ to Charlevoix and Wellington from downtown, and walk home to Ash Ave without being scared or worried that I would be $\mathrm{m}$ urdered. The Point was all about community, if you didn't know someone they knew you because of your parents or other family members. ${ }^{247}$

These traits are imm ortalized in s everal works of fiction that have becom e commonly accepted symbols of what life was like. While current and historic differences between members can be "glo ssed over in a communally accepted sy mbol", ${ }^{248}$ Cohen

\footnotetext{
246 John Mahar, "Point Saint Charles "The Point"," accessed, January 12, 2011.

${ }^{247}$ Pam Hanley-Kearney, “What makes "The Point" Special?," accessed, January 30, 2011.

${ }^{248}$ Cohen, The Symbolic Construction of Community, 15.
} 
points out the "sharing of the sym bol is not the same as sharing the meaning",249 "people of radically opposed views can find their ow $\mathrm{n}$ meanings in what nevertheless rem ain common symbols" ${ }^{250}$ The use of these sym bols is effective because they are im precise and 'relative similarity or difference is not a m atter for 'objective' assessment; it is a matter of feeling." 251 Shared sym bols that help create community for "Pointers" can be easily manipulated to function as common ground. Several works of fiction fill that role, the most commonly known being The Cornerboys ${ }^{252}$ and Balconville. ${ }^{253}$

The Cornerboys, a novel written and self-publishe d by William Earle Benedict, a former resident, is set in the 1950s, (although published in 2007) and Balconville, David Fennario's bilingual play, is set in the 1970s. Both of th ese works contain elements that certain "Pointers" can relate to, either through personal memory or through stories told by relatives. The Cornerboys highlights the friendships that solidified standing around the corner or engaging in sports, particularly playing football with the PSC Aces and boxing, both prevalent in The $\mathrm{P}$ oint at the time. Balconville highlights the bilingual aspects of The Point, now lauded as a positive, and details the challenges of living in The Point after industry has largely abandoned it. The Cornerboys is endorsed on the homepage of the Point website (and has been for as long as I have been visiting the site) and is available at the local library. Balconville was presented at the Centaur Theater, its script available online and Fennario is well known. It has been exclaimed part of The Point's history on

\footnotetext{
249 Ibid.

${ }^{250}$ Ibid., 18.

251 Ibid., 21.

${ }^{252}$ William Benedict Earle, The Cornerboys (Xlibris Corporation, 2007).

${ }^{253}$ Fennario, Balconville.
} 
one of the Facebook groups. ${ }^{254}$ These m anuscripts become symbols, frequently us ed as the explanation of the way things were, without a discussion of the content being referenced in particular, allowing for independent assessment and interpretation.

An additional symbol, a f ictional film, titled The Point, and produced by the National Film Board of Canada in 2006, appeals to yet another generation of, albeit much younger, "Pointers". Using at-risk teens as writers and actors, the film is set on the cusp of gentrification and tells the m odern day experience of growing-up in The Point with a supernatural twist in the form of a returning spirit of a $m$ urdered girl. As detailed on the NFB's site:

The Point follows this diverse cast of characters as their loosely kn it lives intertwine and collide over a couple of days. On the cusp of adulthood, their stories authentically reflect the mix of violence, spirituality, isolation, sexuality, humour, drugs, cops, thugs and relationships that is teen life in "the Point." The neighbourhood itself provides a critical and unmistakable backdrop as the stories unfold. A long-neglected working-clas $\mathrm{s}$ community of $\mathrm{s}$ mall parks and basketball courts, tiny streets and hous es, abandoned buildings, back alleys, mom-and-pop businesses and industrial zones, it repres ents a gritty in ner-city world on the cusp of development and transition. ${ }^{255}$

While it is difficult to asse ss the impact this $\mathrm{f}$ ilm has had in the neighbourhood, it was lent to me when I first moved by a nearby neighbour who has lived in The Point for most, if not all, of his life. However, the plot of the film itself is interesting. The story revolves around a missing teen who disappeared from a street corner. In the film, the case remains open until the murderer, a rapist, eventually was found to have buried the body in one of the many empty industrial buildings. This pa rallels Sharron Prior's open m urder case that has haunted The Point since March 29 1975.

\footnotetext{
${ }^{254}$ James Alison, "The Point....As WE all know it!!!," http://www.facebook.com/group.php?gid=2258791996\&ref=ts\#!/topic.php?uid=2258791996\&topic=2594, accessed, January 12, 2011.

255 “The Story, The Point," http://films.nfb.ca/thepoint/story.html, (accessed, January 30, 2011).
} 
Sharron went missing on the way to a local pizza parlou r. She was found dead days later in a field in Longueil. Family and friends have set up a website devoted to her memory and to solicit leads on her case, th e website also has a guestbook, and posts are made fairly frequently; since its inception in January 2006, there have been 26681 visits to the site. ${ }^{256}$ The case was recently featured on the True Crim es Diary website, ${ }^{257}$ thepoint.ca provides a link to the website, a nd Sharon's disappearance was raised during my interview with Rita W alters where she ech oed most of the sentiments of shock, and sadness, expressed in relation to the event. ${ }^{258}$ Since 2004, there has been a $\mathrm{m}$ emorial scholarship in Sharron's name and a plaque with a short biography is found on the walls of the lo cal YMCA. ${ }^{259}$ Sharron' s disappearance unite $s$ the various generations of "Pointers" and provides a common link between the visitors to thepoint.ca, who generally are of the generation who would have remembered Sharron as a teen, the Facebook group who by and large would have been Sharron' s peers at the time of her disappearance and the youth who produced the film who would ha ve remembered her from their parents' stories.

Sharron's story has becom e a symbolic unifier for people of The Point who are aware that "[ $\mathrm{t}]$ his is an ope $\mathrm{n}$ wound that will never heal fo $\mathrm{r}$ everyone from the Point.",260 Sharron's case is particular as there have since been at leas $t$ two other cases of $m$ issing girls: Tammy Leaky in 1981 and Jolene Riendeau in 1999. Ta mmy's body was also found in a nearby field, and Jolene rem ains missing. Both girls were younger than

\footnotetext{
${ }^{256}$ according to the site's counter. This does not indicate unique visitors, "Sharron Prior's website," http://www.sharronprior.com/. (accessed, August 4, 2010)

257 “True Crime Diary,” http://www.truecrimediary.com/. (accessed, August 4, 2010)

${ }^{258}$ Walters, interview.

${ }^{259}$ In 2004 a "Hall of Recognition" was launched to recognize residents from Point Saint Charles who had made a contribution to the community. In its inaugural year a scholarship for Sharron and Robert O 'Donnell, a youth who had drowned in 1969 were established.

${ }^{260}$ Paul C. "guestbook from sharron," http://www.a-free-guestbook.com/guestbook.php? username=sharron.
} 
Sharron when they went $\mathrm{m}$ issing. Aside from the tragic nature of the story, the initial loss of Sharron challenged the assumptions of a safe community where people knew and looked out for each other; no one has come forward having seen Sharron's abduction and the killer is presum ed to have known the ar ea well. The case has since solidified and unified this community of "Pointers" who can remember this case, either first hand or via their family memories.

Recently, a new visual symbol has been added to unite "Pointers". For the last six years community members have designed and produced a baseball cap to raise funds for unidentified community groups operating in The Point. The cap changes annually and a limited number of caps are produced; ${ }^{261}$ every year the cap sells-out faster than the y ear before. In 2008 "all caps were either sold or were reserved for pickup, and all within a 14 day period! That was a record in the five years we have been selling caps for the benefit of needy groups here in the Point". ${ }^{262}$ The cap is a physical representation of the symbolic boundary between those accepted in this definition of "Pointers" and those who are not. Arguably anyone coul d buy a cap, but they are m arketed to "Pointers", to those "in the know", and th eir scarcity effectively limits possession to m embers of this community. Sold through thepoint.ca, caps are shipped to purchasers wherever they reside, in fact shipping anywhere in Canada via Canpar is covered. ${ }^{263}$ The caps are visible in The Point, people wear them daily, and anyone with knowledge of the meaning behind this symbol is quickly ab le to iden tify wearers as m embers of the comm unity. This is particularly the case during one very important event that annually sees a number

\footnotetext{
${ }^{261}$ In 2009 there were 288 caps produced.

262 George McRae, “Thepoint Guest Book,” March 8, 2009.

${ }^{263}$ George McRae, Ibid., July 14, 2009.
} 
of "Pointers" make the trek back to the place they are recreating: Th e Make a W ish softball tournament.

The softball tournament, a symbol for the community, has also become a ritual. This event is important to "Pointers" because:

the symbolic expression of community and its boundaries increases in importance as the actual geo-social boundaries of the comm unity are undermined, blurred or otherwise weakened. Evidence to substantiate this thesis may be found not only in settled co mmunities but also among those whose members have been dispersed and for whom ritual provides occasions to reconstitute community.",264

Participation implies inclusion in the community and this event is used to help define the boundaries. The annual softball tournam ent, 2010 was the $18^{\text {th }}$ year, brings together "Pointers" and succeeds in raising larg e sums of $\mathrm{m}$ oney for the Make a W ish Foundation. ${ }^{265}$ However, the event is not publicize d. Posters do not pe pper the streets, announcements are not widely ci rculated. The infor mation about the event is circulated only among people perceived as included. Memb ers of the thepoint.ca, and those that still communicate with old fr iends and family, know how to tap into this information whereas new residents do not. The event is later discussed and reminisced about, "What a great atmosphere at the Friday night Poin t Wish Tournament! It was wonderful to see the large amount of people out enjoying them selves", ${ }^{266}$ and hundreds of photos and several videos are added to thepoint.ca.

The tournament appears to replace an older celebration in The Point. The original event, known either as the Queen' s Birthday or firecracker night, would bring people back to The Point to join in the festivities:

\footnotetext{
${ }^{264}$ Cohen, The Symbolic Construction of Community, 50-51.

${ }^{265}$ Myers, "Thepoint Guest Book," April 19, 2010.

${ }^{266}$ Lois Bateman Staveley,Ibid., August 1, 2009.
} 
On the Que en's birthday, we would walk up a nd down Charlevoix street and meet people we hadn't seen in years, m onths, they'd come from, well now they live in Verdun, now they live in Lasalle, they'd all congregate here, they' $\mathrm{d}$ set bonfires in the middle of the street and cops would chase them... different things would go on and it was just... the highlight of the year. ${ }^{267}$

When the annual celebration grew out of cont rol, and after failed attempts at holding organized events in As h Park, the Queen's Birthday ceased to be an occasion in The Point: "Now what's kind of a substitute is the Wish Foundation ... I went once and I ran into all kinds of people I haven't seen for a donkey's age and it was kind of nice". ${ }^{268}$ The memory of these eve nts, either the or iginal May $24^{\text {th }}$ celebrations or the softball tournaments, continue to play an important role in the cre ation of this community and shrink the historical differen ces between "Pointers". W ith these types of even ts, as Blokland points out, "[t]heir $\mathrm{r}$ itual character implies that one did not need to have been present on the very same Queen's Day in order to share in its recalling."269 Memories of this event are mostly vague and exp ressed as a facet of The Point that was special and unique: "Watching an actual bom b fire blaze at the corner of Coleraine and Charlevoix from my grandparents balcony on fire cracker night (bet not too many city kids get to see that!)

Despite the accep tance and sharing of this symbol its memories are not alway $\mathrm{s}$ united. Contribu tors to thepoint.ca recen tly argued over the details of the event, particularly where the wood came from for the annual bonfires. ${ }^{271}$ The storage space for the wood was debated back and forth, with aut hority derived from experience and age at the time in question:

\footnotetext{
${ }^{267}$ Walters, interview.

268 Ibid.

${ }^{269}$ Blokland, "Bricks, Mortar, Memories," 280.

${ }^{270}$ Christina D. Roberts, "What makes "The Point" Special?," Accessed, April 23, 2010.

${ }^{271}$ John O'Conner, “Thepoint Guest Book," May 30, 2010.
} 
Remember, you were just a baby, or maybe just a glint in the eye, at that time. I was only a kid, $m$ yself, and at that tim e you had to be really young. Wasn' t trying to place blame, just as I remembered it! ${ }^{272}$

In response, John O'Conner asse rts his side of the story, an d challenges the authority of the previous contributor before diffusing the dissent:

But me being younger then you, and Alic e hung around with your older brother and he being older then you, and then you caculate that the fire wood was in my back yard, I don' t know how you c an determine that.In any case Art you are right about the fish and chip store and the thrift stop \& shop because they did not have back yards, but there was 5 other back yards of that lain way. So my friend lets not turn this in to a Calamity Jane. $[\text { sic }]^{273}$

By challenging the fixation on the details John returns the $m$ emory to "undefined" allowing for the event to once again becom e an important unifier of "Pointers", despite their differences.

The need to hold onto the memory of the way the Point once was is symbolically recreated by the support of the various fictiona 1 works, the memory of Sharron Prior, the selective softball tournament and the sale of the baseball caps, and gives the appearance of continuity that "obscures people's r ecognition that the form itself has changed." 274 In keeping with Cohen's argument "the reality of community lies in its member's perception of the vitality of its cultur e. People c onstruct community symbolically making it a resource and repository of meaning and a referent for identity." 275 These symbolic ways of maintaining the community " $\mathrm{m}$ asks or lim its the trauma of change". ${ }^{276}$ Thr ough events and online social networks "Pointer s" are responding to a perceived threat, an

\footnotetext{
${ }^{272}$ Alice Mossey, Ibid., May 31, 2010.

${ }^{273}$ John O'Conner, Ibid., June 3, 2010.

${ }^{274}$ Cohen, The Symbolic Construction of Community, 91.

${ }^{275}$ Ibid., 118.

${ }^{276}$ Ibid., 94.
} 
"encroachment on their boundaries", ${ }^{277}$ and reasserting the im portance of community construction to their identities.

On warm days, balconies, front stoops, and even sidewalks of The Point, fill with residents grabbing a refreshing drink, or just gossiping with neighbours. Backyards also explode with laughter and conversation, hostin g people who chose privacy rather than exposure. These spaces can illustrate the co mplexity and difference within Point Saint Charles and anyone privy to the conversations can likely hear divisions. Elsewhere similar discussions are being hosted online, pu blic in a sense and private at the sam e time. W hile online contribu tors lament the loss of behaviours they have deem ed particular to The Point, the act of creating community on a front por ch has not entirely disappeared. W herever creation takes pl ace, the use of "community" often conceals difference. Any normal sunny day in Th e Point can show th e variation betw een residents, but with the passage of time, these com plexities flatten, symbolic cohesion takes their place, and a new community is born.

${ }^{277}$ Ibid., 109. 


\section{Conclusion}

When Joe Beef died on January $15^{\text {th }}, 1889$, at the age of 54 , his tavern carried on, although with a m arkedly difference purpose. The Salvation Arm y purchased and renamed the tavern "Joe Beef Converted" ${ }^{278}$ and c ontinued to offer som e of the social services that Joe had provided: "Masters in adapting popular cultur e to their religious beliefs, the Salvation Arm y transformed one of their most troublesome enemies into a profit for bread and salvation."279 It seems that Joe Beef's memory has been invoked and converted many times since then, both in and outside of The Point. His m emory serves as a reminder of the shifting nature of place, an example of long-standing class relations, and as window into the use and construction of community.

Beef is but one exam ple of the $\mathrm{w}$ ays in which history can be used to $\mathrm{m}$ ake meaning in the present. Trivia style qu izzes pepper the guestbook at thepoint.ca. Questions are focused on the landscape and so cial dynamics of The Point; they ask what business was once found on a certain corner, what year a certain event o ccurred in, what the old name, or nickname, was for a certain location and they reference even ts that no longer take place. Website regulars compile and post their answers to the posed questions while discussing reawakened memories or sharing related anecdotes. Once discussion has died out, the original poster supplies their answers. These quizzes are not relevant to everyone who visits the site; they are linked to a particular tim e of life in The Point. However, the explicit process inherent in the quizzes, remembering the past, recreating place, and reinforcing comm unity, is also oc curring subliminally; the creation of Po int Saint Charles is constantly changing.

\footnotetext{
${ }^{278}$ DeLottinville, "Joe Beef of Montreal," 37.

${ }^{279}$ Ibid.
} 
Interpretations of the past are com plicated, as is the history itself. Conflicted and contested, time periods are presented diffe rently depending on the nature of the recollection. W riting about the future of Canadian National Yards, Gisèle BarryTurgeon, president of the Société d'histoire de Pointe Saint Charles writes:

Premièrement, nous ne pouvous que nous réjouir de la perspective de ressusciter le rôle historique du transport ferroviaire dans le quartier. Un juste retour des choses, quoi. Cet endroit est stratégi que, il l'a toujours été. P our les Amérindiens comme pour les promoteurs de la construction du pont Victoria et de la présence du Grand Tronc. Et si l'importance stratégique sem ble avoir disparu ces dernières an nées, c'est tout simplement qu'elle aurait été niée au nom d'une pseudo modernité qui semble faire fi de tout, voire de la géographie meme des lieux ou du besoin et du plasir du voyageur de pouvoir s'orienter en arrivant á la gare. ${ }^{280}$

Here, the prom inence of The Point's industr ial past confirm $s$ the area's strategic importance. The past i s unified and the "sm okestack nostalgia" 281 evident. However, personal narratives can contradict this view:

Things like we take for granted like a social security number didn't always exist, you understand, so during the Depression my dad told me he worked for $\mathrm{CN}$ but under two or three different nam es, and he always gave an English sounding name. So our name was Smyk, it was four letters, lot of people can't pronounce it... so he'd tell him well his name was Murphy, Connally, because most of the bosses were English 'ah a Murphy - I'll take this guy' you know wha t I mean, and he was a big dude, so they'd take hi $\mathrm{m}$ and he'd work and then they would say to him 'you're only going to work two days cause we gotta give a chance to somebody else' okay so he'd go back in the lineup, but they had different hiring areas, you see, and this time he'd give his name as something else so they'd look on the list 'oh okay, this guy can work, he needs a c ouple of days' so he'd actually get a full weeks work. ${ }^{282}$

These two descriptions come from different sources, yet they could stand-in for much of the historical representation. If history is largely interpretive, then variance should be the norm.

\footnotetext{
${ }^{280}$ Gisèle Barry-Turgeon, "Remettre le quartier Pointe-Saint-Charles sur ses rails," Société d'histoire de Pointe-Saint-Charles: Bulletin, April 20, 2007.

${ }^{281}$ High and Lewis, Corporate Wasteland, 94.

${ }^{282}$ Smyk, interview.
} 
Even so, mem ory and public history ofte $\mathrm{n}$ shape the story being told into a communal vision with specific purposes. The presentation of the area's humble pastoral period, the hard-working zenith of industrialization, and its dignified and resistant period of industrial decline inf orms newcomers of the values that The Point espouses. This construction serves to "put them in their place" within the story. Even here, there is no doubt that the $\mathrm{m}$ eaning behind place is itself varied. In The Point, place is o ften uncritically reduced to its firm physical bounda ries. However these delineations evoke the strong symbolic meanings behind them, representing a sense of separateness from the city at large and standing as a testam ent to the changing econom ic cycles where they have become the physical $\mathrm{m}$ anifestation of the constitutive narrative. These fir $\mathrm{m}$ geographical boundaries encourage the perception of a non-ambiguous use of community as locality, where in siders are determ ined by virtue of residenc $y$ with the accepted delineation. This use of comm unity is being challenged by the influx of new residents who are part of The Point by value of their residency, but who might not fit the traditional demographic.

This thesis offers a unique vantage point in to the effect of indus trial decline in an area where there were once a large num ber of industrial em ployers within walking distance. Unlike in Youngstown, residents of The Point did not contend with the pain of losing one mill and the area 's job identity : no single employer dominated this neighbourhood. Rather it lo st many employers, factories, and multiple work identities. While the responses to deindustrialization were similar - typically involving the need to stress the original strategic importance of the area, an expression of grief and loss, and an insistence of the importance of clas s identity - the outcom e was different. In a m ulti- 
industry landscape, employment meant difference - people worked in the $\mathrm{CN}$ rail yards, Northern Electric, or Redpath Sugar, am ong others - job loss and cl osures lessened this variance. Unem ployment erased differences and predominant iden tities shifted fro $\mathrm{m}$ workplaces to the neighbourhood. In other words, industrial decline unified the population.

As such, while the potential for loss as the enduring m emory of industrial decline was still strong in The Point, a narrative base $\mathrm{d}$ on ideas of a united fr ont and a history of resistance took hold instead. That this story is dominant requires a solid notion of class position, public m emory, pride, and assum ptions of community. The driving force behind this public $\mathrm{m}$ emory is the story of Th e Point's activism. If $\mathrm{r}$ esistance is the unifier, than highlighting success is paramount. Local organizations frequently achieved their aims and adjusted their actions according to unique pressures in the area. As s uch, they are able to discount situations where the outcome was not what they had hoped and emphasize those where it was. The hom ogenizing undertone actively creates an "us" versus "them" mentality, one that was present in the past, and one that is now reinforced by gentrification in the present. That th e new population did not once stand united with The Point is another way that long-time residents position th emselves as different, and imply that in an undefined past, Point Saint $\mathrm{Ch}$ arles' residents were a cohesive whole. However, like the variance of individual $\mathrm{m}$ emories, there have always been levels of divergence between residents of The Point

Despite the obvious differences, at leas $t$ one comm unity is actively suppressing these inconsistencies to create connection. Anthony Cohen reminds us that:

Innumerable studies have shown us 'community' within the city. The history of community action over the last twenty-five years has reminded us, if we needed 
reminding, that people $\mathrm{m}$ ap out their soci al identities and find their social orientations among the relationships which are symbolically close to them rather than in relation to an abstract sense of society. ${ }^{283}$

That said, while this community of "Pointers" is very important to the people that identify as members, it can also be im portant to those seeking the social connection that community offers. There is no doubt that others, like myself, feel a connection to the place, are involved with various community organizations or initiatives, and identify with the area without being included. W ith time, it is evident that some will be abs orbed within the flexible definition and others will, like numerous people before them, live in the area without feeling the attachm ent that would make The Point an important part of their identity.

It would be presum ptuous of me to expect automatic acceptance into this community. What the place of Point Saint Charles means for me, as a new resident who has only experienced the neighbourhood in its current economic cycle is no doubt very different from a person who lived in th e neighbourhood when the air was choked by industrial fumes, and again dif ferent from the person who experienced the devastation that came with the ind ustrial decline and mass unemployment in the area. Given the nature of econom ic changes that have crea ted the place of Point Saint Charles it is perhaps of no surprise that its $\mathrm{m}$ aking has a large class component. The identity of The Point is veering away from a working-class neighbourhood to one that is lar gely mixed, and yet the memory of the area remains and influences the understanding of place.

In any case, various communities can be seen when one looks at the use of the term community rather than seeking a definiti on. Here, I have only addressed two of the common uses when looking at The Point, one th at perceives residency as inclusion, and

${ }^{283}$ Cohen, The Symbolic Construction of Community, 27. 
one that has no such requirem ent. I have no $t$ addressed various ot her conceptions that exist and one particularly glaring om ission is the new community bein g created with the wave of ge ntrification. Shar on Zukin argues that new residents com e to an area in a quest for the authenticity of a neighbourhood yet they bring with them their own tastes. This starts with "new retail entreprene urs [who] often move into a neighbourhood as residents and can't find a place to buy a good latte..." but these new for ms of cultural consumption result in older stores closing a nd eventually major chains moving in. Thus that initial authenticity is lost. ${ }^{284}$ There is no doubt that areas in Montreal have followed this pattern. For example, the Plateau, now a high-priced, s ought-after neighbourhood was once an area in transition. Its roots as w orking class, and its role as imm igration corridor, are largely no longer posited as the reason for its authenticity. Despite this, it is still lauded as a un ique place within the city because it has created "the experience of origins" through its preservati on of historical buildings a nd the encouragement of smallscale establishments. ${ }^{285}$ In term s of consumer consumption The Point is not yet ther e. While retail outlets that would appeal to a new population do dot Centre Street, stores in The Point are lacking in general, services have unequivocally not yet caught up with housing prices. Has The Point then retained, for the moment, its authenticity?

At issue here is where this authenticity is housed, in the people or the place? In The Point the loss of storefronts $\mathrm{p}$ receded gentrification; they closed with the industrial decline and the accompanying drop in population. Did Point Saint Charles then lose its authenticity when people were forced to $\mathrm{m}$ ove, or with the changes in the housing stock, which remains at the m oment the largest indicator of a period of urban change? At the

\footnotetext{
${ }^{284}$ Sharon Zukin, Naked City: The Death and Life of Authentic Urban Places (Oxford University Press, USA, 2009), 20.

${ }^{285}$ Ibid., 3.
} 
root of these issues is an undefined idea of authenticity. Likely some new residents of Point Saint Charles have selected the neighbourhood because they perceive it to $h$ ave an authentic aura or the patina of ag e appeals to them. That s aid, longtime residents both current and former continue to lament the loss of the "way things were". Are they not in fact protesting the lack of authen ticity? Ultimately, interpretations of "authentic" a re destined to vary as greatly as conceptions of place; after all doesn't on e depend on the other?

In any case, Zukin's appro ach to gentr ification in New York City $r$ ests on the assumption that at the root everyone seeks to $\mathrm{m}$ ove into a particular neighbourhood because of its cultural capital. In Detroit, John Hartigan observed that:

[p]redominantly, the recently arrived whites are engaged in re habilitating single homes they have purch ased and where they now reside. They contrasted the scope of these actions against what they posited as true gentrification, which entails the wholesale removal of old timers. ${ }^{286}$

The complexity and motivations behind the ch oices that have brought new residents to Point Saint Charles can only be inferred, but it is likely that many do not associate themselves with the consequences of gentrification. While "the wholesale removal of old timers" might not have been $m$ ine, or their, motivation there is no doubt that this can be the result. However, I cannot help but recall when I began looking to purchase a house. Current housing prices meant that the neighbourhood that I was raised in was no longer accessible to me. I was not al one; my peers were relocating in droves, most to various suburbs off the Island of Montreal, because they too co uld not afford to raise their children where they had grown up. Even thoug h our options are clearly greater, perhaps gentrifiers have also found them selves in a certain way displaced? Whatever the cause,

${ }^{286}$ HartiganJr, "Remembering White Detroit," 25. 
periods of urban change, and particularly gent rification, are transformative and what will become of The Point remains to be seen.

Current Montrealers might be familiar with o ther establishments that bear Jo e Beef's name; Notre Dame Street, in Little Burgundy, on the opposite side of the Lachine Canal from The Point hosts two restaurants; Joe Beef and McKiernan. ${ }^{287}$ Yet, Joe Beef's original patrons would have nev er been ad mitted to these ea teries. Like the neighbourhood that surrounds them, these re staurants have been transfor med beyond recognition. In this, Joe Beef 's final role for The Point is one of warning. Little Burgundy once served as a cautionary tale fo $\mathrm{r}$ destructive urban "renewal", now its message warns against gentrification that could render The Point unrecognizable.

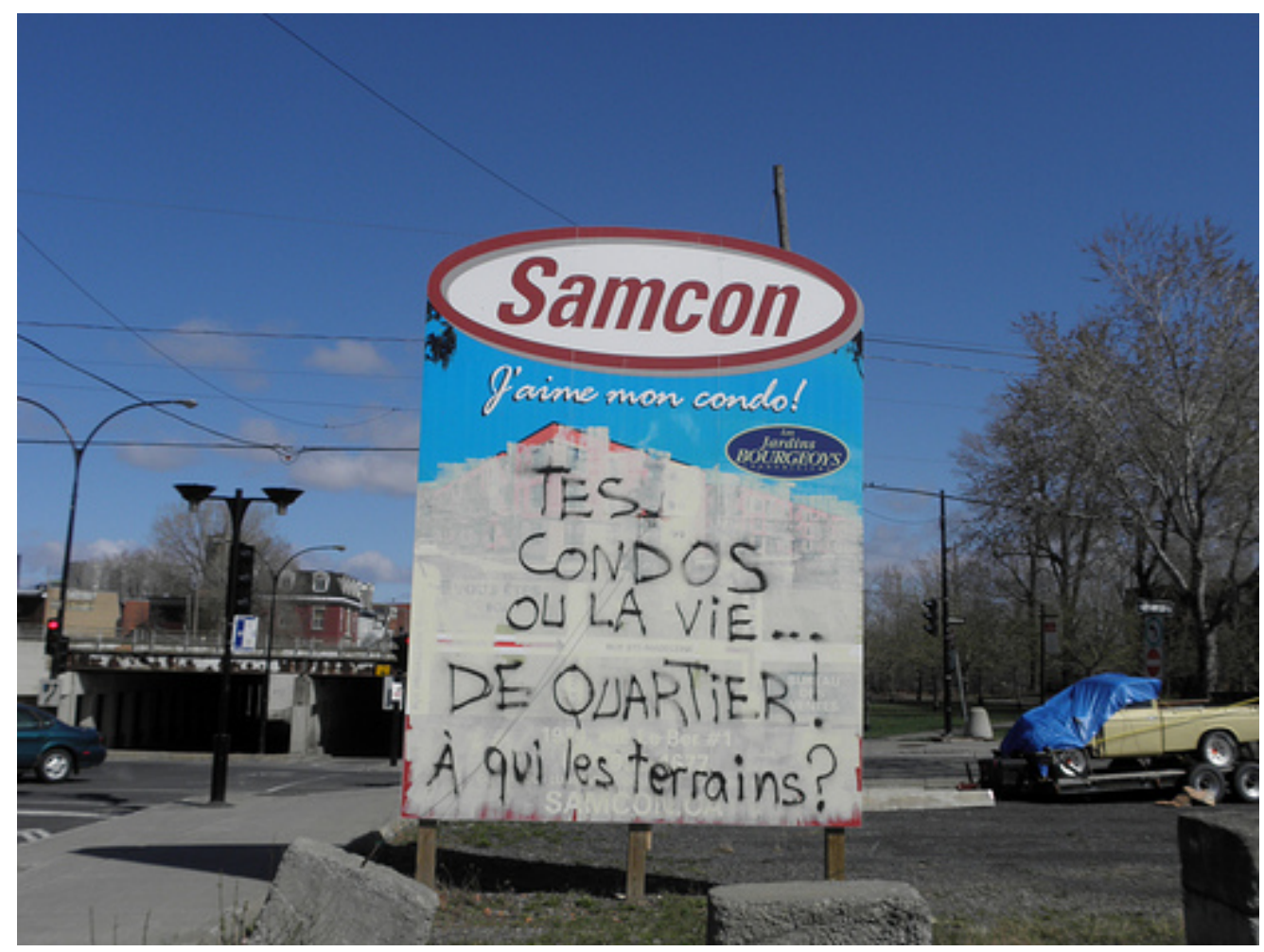

Figure 5.1: Whose land? Source: Flickr, by La Pointe Libertaire.

\footnotetext{
287،Joe Beef, Liverpool House, McKiernan : Notre Dame West, Montreal, Qc. Canada," http://www.joebeef.ca/. (accessed, January 12, 2011)
} 


\section{Bibliography}

\section{Archival Sources}

Bibliothèque et Archives nationales du Québec

Plans de villes et villages du Québec

McGill University Archives

MG4263: the Popular Archives of Pointe Saint Charles

Société d'histoire de Pointe-Saint-Charles

\section{Interviews}

Anonymous. Interview by Jessica J. Mills, March 23, 2010.

Courte Pointe Collective. "Tissons une courtePointe: L'histoire de l'action communautaire a travers les histories de vie de femmes de Pointe St-Charles.." Interview by Isabelle Drolet and Anna Kruzynski, February 12, 2002.

. "Tissons une courtePointe: L'histoire de l'action communautaire a travers les histories de vie de femmes de Pointe St-Charles.." Interview by Isabelle Drolet and Anna Kruzynski, March 13, 2002.

— . "Tissons une courtePointe: L'histoire de l'action communautaire a travers les histories de vie de femmes de Pointe St-Charles..” Interview by Isabelle Drolet and Anna Kruzynski, March 26, 2002.

_ . "Tissons une courtePointe: L'histoire de l'action communautaire a travers les histories de vie de femmes de Pointe St-Charles.." Interview by Isabelle Drolet and Anna Kruzynski, May 7, 2002.

Martello, Mike. Interview by Jessica J. Mills, November 28, 2008

Smyk, Denis. Interview by Jessica J. Mills, October 28, 2008.

Walters, Rita. Interview by Jessica J. Mills, December 2, 2008.

\section{Newspapers}

The Globe and Mail

The Gazette (Montreal)

The Montreal Star

The New York Times

Toronto Star

\section{On-line Sources}

Action-Gardien, http://actiongardien.org. (accessed 27 January 2011).

"Asterix Encyclopedia - Translations - Asterix in Latin - The official Website." http://www.asterix.com/encyclopedia/translations/asterix-in-latin.html. (accessed 3 September, 2010).

"Centre social autogéré." http://www.centresocialautogere.org/en/node. (accessed 3 June, 2010) 
"Comité de résistance au Nordelec (CRAN)." http://www.nordelec.net/cran_en.(accessed 3 June 2010)

“Comité NTU." http://www.nousetlestrains.org/wp/. (accessed 3 June, 2010)

"Fennario, David. Canadian Theatre Encyclopedia."

http://www.canadiantheatre.com/dict.pl?term=Fennario\%2C\%20David. (accessed 26 October 2010)

"Griffintown and Point St. Charles Heritage Trail | Montreal Mosaic WebMagazine." http://montrealmosaic.com/attraction/griffintown-and-point-st-charles-heritagetrail. (accessed 12 April, 2010)

"Heritage and quality renovation guide." City of Montreal. http://www.operationpatrimoine.com/guide/index_eng.htm. (accessed 23 October, 2010)

"Joe Beef, Liverpool House, McKiernan: Notre Dame West, Montreal, Qc. Canada." http://www.joebeef.ca/. (accessed 12, January, 2011)

"La Pointe Libertaire" http://www.lapointelibertaire.org. (accessed 3 June, 2010)

"Maison Saint-Gabriel, située près du Vieux-Montréal, Montréal, Québec, Canada." http://www.maisonsaint-gabriel.qc.ca/index.html. (accessed 1 April, 2010)

"McKiernan, Charles." Dictionary of Canadian Biography Online. http://www.biographi.ca/009004-119.01e.php?BioId=39816\&query=joe\%20AND\%20beef. (accessed 2 July, 2010)

"Parks Canada - Lachine Canal National Historic Site - The Cradle of Industrialization," http://www.pc.gc.ca/eng/lhn-nhs/qc/canallachine/natcul/natcul2/c.aspx. (accessed 2 July, 2009)

"Point Saint Charles "The Point"." www.facebook.com. http://www.facebook.com/\#!/group.php?gid=2258791996. (accessed 11 January, 2011)

"POINTE ST-CHARLES." www.facebook.com. http://www.facebook.com/\#!/group.php?gid=50293771335. (accessed 11 January, 2011)

"Population counts, for census metropolitan areas and census agglomerations by urban core, urban fringe, rural fringe and urban areas, 2006 census - 100\% data." http://www12.statcan.ca/english/census06/data/popdwell/Table.cfm?T=207\&CM $\mathrm{A}=505 \& \mathrm{~S}=0 \& \mathrm{O}=\mathrm{A} \& \mathrm{RPP}=25$. (accessed 3 June 2010) 
"PSC born and raised." www.facebook.com.

http://www.facebook.com/\#!/group.php?gid=2364709526. (accessed 11 January, 2011)

"Multiple Listing Service (MLS) REALTOR.ca" http://www.realtor.ca/index.aspx?cul=1 (accessed 11 January, 2011)

"Regroupement Information Logement et la Société d'amélioration de Pointe-St-Charles (R.I.L SOCAM)." http://www.rilsocam.org/. (accessed 3 October, 2010)

"Saint Columba House.” http://www.facebook.com/\#!/group.php?gid=20393131756. (accessed 16 January, 2010)

"Saint Columba House." http://www.saintcolumbahouse.org/. (accessed 11 November, 2010)

“Sharron Prior's website.” http://www.sharronprior.com/. (accessed 4 August, 2010)

"Société d'histoire de Pointe-Saint-Charles." http://www.histoirepointesaintcharles.org/histoire.html. (accessed 15 November, 2010)

"The Story, The Point." http://films.nfb.ca/thepoint/story.html. (accessed 30 January, 2011)

"The Point Website Guest Book." thepoint.ca. http://www.websitetoolbox.com/tool/gb/gwmcrae. (accessed, 11 January, 2011)

“True Crime Diary.” http://www.truecrimediary.com/. (accessed 4 August, 2010)

"Ville de Montréal - Habiter Montréal - Rénovation résidentielle majeure." http://ville.montreal.qc.ca/portal/page?_pageid $=4977,15819740 \& \_d a d=$ portal\&_s chema=PORTAL. (accessed 23 May, 2010)

"Ville de Montréal - Patrimoine urbain - Programme d'aide à la restauration." http://ville.montreal.qc.ca/portal/page?_pageid $=2240,18491562 \& \_d a d=$ portal\&_s chema=PORTAL. (accessed 23 May, 2010)

\section{Published Primary Sources}

Ames, Herbert Brown. The City Below the Hill: A Sociological Study of a Portion of the City of Montreal, Canada. Social history of Canada. Toronto: University of Toronto Press, 1972. 
Earle, William Benedict. The Cornerboys. Xlibris Corporation, 2007.

Feltoe, Richard. Redpath: The History of a Sugar House. Toronto: Natural Heritage/Natural History, 1991.

Fennario, David. Balconville. 1st ed. Alexandria, VA: Alexander Street Press, 2007.

—. Blue Mondays. Verdun, Quebec: Black Rock Creations, 1984.

—. Joe Beef : A History of Pointe Saint Charles. Vancouver: Talonbooks, 1991.

Gisèle Barry-Turgeon. "Remettre le quartier Pointe-Saint-Charles sur ses rails." Société d'histoire de Pointe-Saint-Charles: Bulletin, April 20, 2007.

Kruzynski, Anna, and Isabelle Drolet, eds. The Point Is-- Grassroots Organizing Works: Women from Point St. Charles Sharing Stories of Solidarity. Montréal: Éditions du remue-ménage, 2006.

Northern Telecom. "The Close of an Era. Shearer Edition..” Cablogramme/Cablegram.

Société d'histoire de Pointe-Saint-Charles. A Brief History of the Streets and Parks in Point Saint Charles. 3rd ed. [Montréal]: Éditions Histoire Québec, 2009.

\section{Secondary Sources}

Blokland, Talja. "Bricks, Mortar, Memories: Neighbourhood and Networks in Collective Acts of Remembering." International Journal of Urban and Regional Research 25 , no. 2 (6, 2001): 268-283.

Bourdieu, Pierre. "The social space and the genesis of groups." Theory and Society 14, no. $6(11,1985)$. http://www.springerlink.com/content/g71vq126122114t0/.

Bradbury, Bettina. Working Families: Age, Gender, and Daily Survival in Industrializing Montreal. University of Toronto Press, Scholarly Publishing Division, 2007.

Burns, Patricia. The Shamrock and the Shield: An Oral History of the Irish in Montreal. Dossier Québec series. Montréal: Véhicule Press, 1998.

Butler, T. "Memoryscape: how audio walks can deepen our sense of place by integrating art, oral history and cultural geography." Geography Compass 1, no. 3 (2007): 360-372.

Certeau, Michel de. The Practice of Everyday Life. Berkeley: University of California Press, 1988. 
Chidester, R. C, and D. A Gadsby. "One Neighborhood, Two Communities: The Public Archaeology of Class in a Gentrifying Urban Neighborhood." International Labor and Working-Class History 76, no. 01 (2009): 127-146.

Cohen, Anthony P. The Symbolic Construction of Community. Key ideas. Chichester: E. Horwood, 1985.

Copp, Terry. The Anatomy of Poverty: The Condition of the Working Class in Montreal 1897-1929 (Oxford). McClelland \& Stewart, 1974.

Cresswell, Tim. Place: A Short Introduction. Short introductions to geography. Malden, MA: Blackwell Pub, 2004.

Davis, Fred. Yearning for yesterday: A sociology of nostalgia. Free Press New York, 1979.

DeLottinville, Peter. "Joe Beef of Montreal: Working-Class Culture and the Tavern, 1869-1889.” Labour/Le Travail 8 (1981): 9-40.

Faue, Elizabeth. "Community, Class, and Comparison in Labour History and Local History.” Labour History (2000): 155-162.

Fritzsche, Peter. "Specters of History: On Nostalgia, Exile, and Modernity." American Historical Review 106, no. 5 (2001): 1587-1618.

Graaf, Peter Van Der. Out of place? Emotional Ties to the Neighbourhood in Urban Renewal in the Netherlands and the United Kingdom. Amsterdam University Press, 2009.

Harley, J.B. "Maps, knowledge, and power." In The Iconography of Landscape: Essays on the Symbolic Representation, Design, and Use of Past Environments, edited by Denis E Cosgrove and Stephen Daniels. Cambridge studies in historical geography 9. Cambridge [England]: Cambridge University Press, 1988.

Hartigan Jr, J. "Remembering White Detroit: whiteness in the mix of history and memory." City \& Society 12, no. 2 (2000): 11-34.

Harvey, David. "Between Space and Time: Reflections on the Geographical Imagination." Annals of the Association of American Geographers 80, no. 3 (1990): 418-434.

High, Steven C, and David W Lewis. Corporate Wasteland: The Landscape and Memory of Deindustrialization. Toronto: Between the Lines, 2007.

Lefebvre, Henri. Critique of Everyday Life. London: Verso, 1991. 
Lewis, Robert. Manufacturing Montreal: The Making of an Industrial Landscape, 1850 to 1930. The Johns Hopkins University Press, 2000.

Linkon, Sherry Lee. Steeltown U.S.A: Work and Memory in Youngstown. Culture America. Lawrence, Kan: University Press of Kansas, 2002.

Low, Setha. "Symbolic Ties that Bind: Place Attachment in the Plaza." In Place Attachment, edited by Irwin Altman, 165-185. Plenum Press, 1992.

- Behind the Gates Life, Security, and the Pursuit of Happiness in Fortress America. New York: Routledge, 2003.

Marsan, Jean Claude. Montreal in Evolution: Historical Analysis of the Development of Montreal's Architecture and Urban Environment. Lst pbk. ed. Montreal: McGillQueen's University Press, 1990.

Massey, Doreen. “A Global Sense of Place.” Marxism today 35, no. 6 (1991): 24-29.

__. "Places and Their Pasts." History Workshop Journal, no. 39 (April 1, 1995): $182-192$.

Opp, James, and John C. Walsh. Placing Memory and Remembering Place in Canada. UBC Press, 2010.

Overton, James. "Coming Home: Nostalgia and Tourism in Newfoundland." Acadiensis 14, no. 1 (1984): 84-97.

Portelli, Alessandro. "What Makes Oral History Different." In The Oral History Reader, edited by Robert Perks and Alistair Thomson, 32-42. 2nd ed. London: Routledge, 2006.

Scott, Joan W. "The Evidence of Experience.” Critical Inquiry 17, no. 4 (July 1, 1991): 773-797.

Taksa, Lucy. "Like a Bicycle, Forever Teetering between Individualism and Collectivism: Considering Community in Relation to Labour History." Labour History, no. 78 (May 1, 2000): 7-32.

Tuan, Yi-Fu. "Place: An Experiential Perspective." Geographical Review 65, no. 2 (April 1, 1975): 151-165.

Van Criekingen, Mathieu, and Jean-Michel Decroly. "Revisiting the Diversity of Gentrification: Neighbourhood Renewal Processes in Brussels and Montreal." Urban Studies 40, no. 12 (November 1, 2003): 2451 -2468.

Walsh, J. C, and S. High. "Rethinking the Concept of Community." Social 
History/Histoire Sociale 32, no. 64 (1999).

Whelan, R. K. "The politics of urban redevelopment in Montreal Regime change from Drapeau to Doré." Quebec Studies 12 (1991): 155-169.

Zukin, Sharon. Landscapes of Power: From Detroit to Disney World. Berkeley: University of California Press, 1991.

- Naked City: The Death and Life of Authentic Urban Places. Oxford University Press, USA, 2009.

\section{Theses \& Dissertations}

Barlow, John Matthew. ""The House of the Irish": Irishness, History, and Memory in Griffintown, Montréal, 1868-2009." PhD dissertation, Concordia University, 2009.

Bliek, Desmond Andrew. "Reweaving Urban Fabrics: Urbanisation, Industrialisation and Regeneration in Southwest Montréal." MA thesis, Concordia University, 2007.

Mills, Sean William. "The Empire Within: Montreal, the Sixties, and the Forging of a Radical Imagination.” PhD dissertation, Queen's University, 2007.

Tulchinsky, Gerald J. J. The Construction of the First Lachine Canal, 1815-1826. MA thesis, McGill University, 1960. 